\title{
Legal Reform of Special Education: Empirical Studies and Procedural Proposals
}

\author{
David Kirp,* William Buss, ** and \\ Peter Kuriloff $* * *$
}

In the past few years, lawyers have assumed an increasingly active role in disputes over the adequacy of education for the handicapped, promoting particular policy goals both through legislation and in test case litigation. ${ }^{1}$ The first Part of this article briefly describes the education typically provided for the handicapped, noting the criticisms whicl present practices have provoked. It also posits an explanation of the durability of the status quo, drawing upon certain organizational attributes of special education. Part II makes a preliminary assessment of the effects law reform has had on special education through three case studies of sites where courts or legislatures have

* Acting Associate Professor of Public Policy, Lecturer in Law, and Senior Research Associate, Project on Childhood and Government, University of California, Berkeley. B.A., Amherst College, 1965; LL.B., Harvard University, 1968.

** Professor of Law, University of Towa. B.A., Yale University, 1955; LL.B., Harvard University, 1960.

*** Assistant Professor of Education, University of Pennsylvania. B.A., Antioch College, 1965; Ed. D., Harvard University, 1970.

Research for this Article was undertaken for the Project on the Classification of Exceptional Children, Vanderbilt University. A grant from the Ford Foundation and the Carnegie Corporation to the Project on Childhood and Government, University of California, Berkeley also supported the researcl. This Article builds upon earlier articles by two of the authors. See Buss, Procedural Due Process for School Discipline: Probing the Constitutional Outline, 119 U. PA. L. REv. 545 (1971); Kirp, Schools as Sorters: The Constitutional and Policy Implications of Student Classification, 121 U. PA. L. Rev. 705 (1973).

Patricia Wald, an attorney with the Mental Health Law Project, Washington, D.C. was of inestimable lielp in gathering data for this Article. We wish to acknowledge the researcli assistance of Carl Milofsky, Department of Sociology, University of California, Berkeley; Susan Appleton and Ellen Widess, School of Law, University of California, Berkeley; Doris Cohen, Sclool of Education, University of California, Berkeley; Robert True, Scliool of Education, University of Pennsylvania; Paul Thurston, College of Law, University of Iowa; and Frank Wiggins, School of Law, University of Michigan.

1. For an array of the specific problems on which lawyers have been active, see Symposium-The Legal Rights of the Mentally Retarded, 23 SYR. L. REV. 991-1165 (1972). 
mandated substantive or procedural change in educational opportunities for the handicapped. Part III offers a general, and more speculative, appraisal of the utility of one particular legal framework, procedural due process, for making correct education decisions with respect to the identification and treatment of handicapped children.

\section{I}

\section{EDUCATION OF THE HANDICAPPED}

Handicapped, or "exceptional" or "special", children form an extraordinarily diverse group, estimated to include between 8.7 and 35 percent of the entire student population. ${ }^{2}$ From the viewpoint of the general educator, all that the handicapped have in common is that they differ from normal students. Some have problems so severe that their need for special educational attention is self-evident; they hterally cannot survive without almost constant assistance. ${ }^{3}$ The learning deficiency of most exceptional children, however, is slight and hard to detect. ${ }^{4}$ Children who systematically write letters backwards, write in mirror fashion, or seem not to read some letters are common phenoinena in lower elementary grades. ${ }^{5}$ In many cases, children who have physical disabilities which might interfere with learning can not be distinguished by school officials from their supposedly normal classmates. Children with sliglt loss of hearing or sight can often compensate for their difficulty and thus go undetected until a systematic screening program is introduced, as can children with psyclio-linguistic learning disabilities. Typically, state law denies the most severely handicapped youngsters any riglit to publicly supported schooling. For the rest, a bewildering variety of special categories distinguishing both type of handicap (e.g., between blindness and retardation) and severity of handicap (e.g., between educable and trainable retardates) liave been adopted. $^{8}$

2. N.Y. State COMm'N, Report on the Quality, Cost and Financing of ElementaRY AND SECONDARY EDUC. 9B.2 (1972). The spread in the figures is almost wholly accounted for by disparities in estimating the percentage of brain-injured and learning-disabled children.

3. See generally Kirk, Research in Education, in MENTAL RETARDATION 57 (H. Stevens \& R. Heber eds. 1964).

4. See E. Rudin, C. Stmson \& M. Betwee, Emotionaliy handicapped ChilDREN AND THE ELEMENTARY SCHOOL 3132, 3134 (1966). See also Dunn, Special Education for the Mildly Retarded: Is Much of It Justifiable?, in PROBLEMS AND IssUES IN THB EDUCATION OF EXCEPTIONAL CHIIDREN 382 (R. Jones ed. 1971).

5. Compare Kramer, Diagnosis and Classification: Their Purposes and Uses in Epidemiological and Health Services Research with Meyer, Screening and Assessment of Young Children at Developmental Risk (1973) (reports prepared for the Project on the Classification of Exceptional Children, Vanderbilt University).

6. Among the categories of exceptionality which are defined by I.Q. test score are: borderline, mild, noderate, severe and profound niental retardation. See Brison, 


\section{A. Criticisms and Suggested Reforms of Classification Schemes}

\section{The Severely Handicapped}

Most severely handicapped children are classified as ineducable and are denied access to publicly supported instruction. But this practice is inconsistent with the research findings that all children are educable, that is, able through instruction to move from relative dependence to relative independence. Many of these children-estimated to number between 450,000 and $4,000,000^{7}$-spend their entire lives in state-run institutions, which, while providing minimal care, lack the resources to undertake any training in self-help. Private schools licensed by the states do train children with specific handicaps. But because these schools are self-supporting, they generally enroll only children from well-to-do homes. While a few states have sought to alleviate this fiscal inequity by providing vouchers for handicapped youngsters, ${ }^{8}$ the burden of caring for the severely handicapped falls most heavily upon the poor, the group least able to sacrifice the time and energy needed to ensure adequate educational help.

Even when public schools provide some instruction for the severely handicapped, they do not do enough. Autistic children, for example, require costly, highly structured, professionally staffed programs. Placing autistic children im any other type of program is viewed as the functional equivalent of excluding them from school. ${ }^{9}$

These criticisms of the education of severely handicapped children view the public schools as doing nothing, or too little, for this group. The suggested remedy is to create additional special programs or make available additional resources for existing programs for hard-to-educate children. The criticisms provoked by the schools' treatinent of the mildly handicapped, however, are quite different.

\section{The mildly handicapped}

Special programs for the mildly handicapped have been faulted for a lost of reasons: they misclassify students, enroll a disproportionate

Definition, Diagnosis, and Classification, in MENTAL RETARDATION 10 (A. Baumeister ed. 1967). Other categories are: hearing-impaired, visually handicapped, speechimpaired, physically handicapped, brain-injured (both minimally and severely) and emotionally handicapped. See Rossmiller, Resource Configurations and Costs in Educational Programs for Exceptional Children in 3 Nat'l Educ. Fin. Project, Plannino to Finance Education 61 (R. Johns, K. Alexander \& K. Jordan, eds. 1971).

7. Compare The EXclusion of CHIDDREN FROM School 3 (J. Regal ed. 1971) (DHEW Grant OEG-D-70-3126) with 118 CONG. Rec. H1257 (1972) (remarks of Congressman Vanik).

8. See, e.g., CAL. EDUc. CoDe $\$ \S 6870-74.6$ (West 1973).

9. See Tidewater Soc'y for Autistic Children v. Tidewater Bd. of Educ., No. 42672-N (E.D. Va. Dec. 26, 1972). 
share of minority children, appear educationally inefficacious, and too readily become permanent assignments.

\section{a. Misclassification}

"Misclassification," as the critics use that term, ineans two quite different phenoinena. First, it may denote the misapplication of agreedupon criteria. When, for example, the school violates state law by assigning a student with a 100 I.Q., to a class for the mildly retarded, misclassification is evident. If, however, the criteria for classification are more subjective-involving, for example, teacher judgments of student readiness or motivation-problems of misapplication of criteria are considerably more complex.

Misclassification also may denote a dispute over how data are gathered so that established criteria can be applied. Even if a school consistently distinguishes between handicapped and normal students on the basis of a particular test, the test itself may be inadequate or susceptible to inultiple interpretations. Many documented instanees of misclassification are of this variety. In Washington, D. C., for example, the school systein concluded that up to two-thirds of its mildly landicapped students were in fact normal. This reversal in judgment resulted from the substitution of individually administered I.Q. tests for group aptitude tests. ${ }^{10}$ Similarly, in a study of 36 Philadelphia-area school districts, a change in testing indicated that two-thirds of the mildly retarded students were misclassified. ${ }^{11}$ Disputes over the appropriateness of using Englisl-language tests to place non-Englisl-speaking students in special programs pose similar issues. Such tests, critics argue, can determine only the extent of acculturation, not ability. The suggested remedy for improper ineasurement of student ability is the adoption of different testing methods, including individually administered tests and native language or culturally-neutral aptitude tests. Erroneous placements may also be reduced by improving the decision-making procedures which implement present test results.

\section{b. Differential Vulnerability}

That certain types of students are particularly vulnerable to special classification makes the critics uneasy. Not all children are even con-

10. Hobson v. Hansen, 269 F. Supp. 401, 490-91 (D.D.C. 1967), appeal dismissed, 393 U.S. 801 (1968), aff'd en banc sub nom. Smuck v. Hobson, 408 F.2d 175, 187 (D.C. Cir. 1969).

11. See, e.g., Heber, A Manual on Terminology and Classification in Mental Retardation (American Journal of Mental Deficiency, Monograph Supp. 1961); B. Hoffman, The Tyranny of Testing (1962); S. Sarason, Psychological Problems IN Mental Deficiency 482-87 (3d ed. 1959); Chase \& Pugh, Social Class and Performance on an Intelligence Test, 8 J. EDUC. MEASUREMENT 197 (1971), 
sidered for special programs, and those who are do not represent a random sample of the student population. Students who make life difficult for the regular classroom teacher are most apt to have their normal status questioned: more boys than girls ${ }^{12}$ and more aggressive than quiescent students are identified as possibly handicapped. White students typically must display both intellectual and behavioral quirks to be considered for special classification, while intellectual difficulties alone are sufficient to render Black or Mexican-American students suspect. ${ }^{13}$ Non-white students are overrepresented in programs for the mildly handicapped by as much as 250 percent relative to their proportion of the school-age population, ${ }^{14}$ a fact which evokes considerable political concern. Overrepresentation diminishes the possibility of school integration, may diminish the educational opportunities of minority students, and calls into question the legitimacy of the entire system of special education classification. Differential vulnerability may lead the school both to ignore the special needs of students who do not disrupt the classroom and to underestimate the educational potential of minority students. Suggested remedies include early and thorough evaluation of all students, procedural protections so that non-problem children are not overlooked and children particularly vulnerable to classification are not wrongly singled out, and the integration of minority and white students either by abolishing special programs for the mildly handicapped or by setting racial quotas for such programs.

\section{c. Efficacy}

The efficacy of programs for the mildly handicapped frequently has been questioned. Studies comparing the performance of matched groups of students in regular and special programs generally conclude that, despite the additional resources in special programs, special classes generally have either no effect or a slightly adverse effect on both the motivation and achievement of students assigned to them. ${ }^{15}$ Furtherinore, these programs may impose a stigma of "differentness" without securing offsetting benefits. ${ }^{16}$ Only in those rare instances when children with distinct learning disorders are identified early in their educational careers and their special teachers are technically sophisticated do

12. See N. Frazter \& M. SADKER, SEXISM IN School AND SocietY 86-94 (1973).

13. See J. Mercer, Labeling THE MENTALly Retarded 67-82 (1973); cf. Jensen, A Theory of Primary and Secondary Familial Mental Retardation, in 4 INT'L REv. OP REsearch In MENTAL RETARDATION 33 (N. Ellis ed. 1970).

14. See Kirp, Schools as Sorters: The Constitutional and Policy Implications of Student Classification, 121 U. PA. L. REv. 705, 759-62 (1973).

15. See authorities cited in note 4 supra.

16. Jones, Labels and Stigma in Special Education, 38 Exceptional ChILdReN 553, 560-61 (1972); cf. Zito \& Bardon, Achievement Motivation among Negro Adolescents in Regular and Special Education Programs, 74 J. Mental Deficigncy 20 (1969). 
these classes appear to succeed. To some, this demonstrated failure of these programs argues for their abandonment and for the adoption of careful strategies to ease the transition of most, if not all, such children into regular programs. A substantial diminution of the number of mildly handicapped children in special classes could be accomplished by vigorously implementing the presumption that regular classes are preferable to special classes and forcing the school to prove the contrary in each challenged case.

\section{d. Permanent Placement}

Special program assignment for the mildly handicapped is supposed to be temporary, enabling the student ultimately to return to the regular class. In fact, special placements often prove to be permanent assignments: one survey of urban school systems found that fewer than ten percent of the students identified as mildly handicapped ever returned to regular classes. ${ }^{17}$ Regular review of special class placement coupled with a commitment to return students to regular programs as soon as possible, might well resolve this problem.

\section{The Enduring Status Quo}

Despite the flurry of criticism and demands for reform, the education of handicapped children remains largely unchanged: the severely handicapped generally go without education, enrollment in programs for the mildly handicapped continually climbs, and Blacks and other minorities continue to be considered for and classified as handicapped in disproportionate numbers. There is little evidence of improvement in the syndrome of misclassification, imeffective prograns for those classified, and relative irreversibility of the classification decision. The simplest explanation for this lack of change is that those who run the schools are at fault. Critics who take this "blaming" view generally regard the people who staff the present system as imdifferent if not hostile to the fate of the handicapped and the putative liandicapped. Sucl critics believe that change can take place only after "the rascals have been thown out" (or bought out, if tenure laws and umion contracts complicate the issue) and replaced by more humane and child-oriented adults. ${ }^{18}$ This view is probably wrong. There is little justification for the suspicion that educators either dislike students or perversely resist change. Yet two quite different factors-the peculiar nature of "the problem" and certaim structural and organizational attributes of special education programs-together make major changes unlikely.

17. Gallagher, The Special Education Contract for Mildly Handicapped Children, 38 EXceptional Children 527, 529 (1972).

18. The popular literature critical of current public education practice ap- 
Consider first the range of criticism canvassed above. The values upon which the critiques are premised diverge, and the proposed remedies cannot readily be reconciled. Not even the most responsive educational agency could both satisfy middle-class parents by providing diverse and intensive special programs and meet demands froin minority parents that special programs be terminated because of their discriminatory effects. The lack of consensus concerning either the problem or its resolution suggests the wisdom of caution im probing what appears to be a particularly thorny patch of the educational thicket.

Each of the critiques defines a problem in isolation, thus particularizing what may be a more general educational policy dilemma. If the goal is incremental change, particularization may make considerable sense. It is more realistic than the viow of the President's Commission of Mental Retardation that "all education should be special education, because each child is a very special child."10 Such a statement is obviously true, but avoids the politically and organizationally difficult task of identifying at what points the social system resists translating the obvious into practice. Yet the imcrementalist critic of present practices, whatever his particular persuasion, should recognize that change which affects the lives of exceptional children will also touch the lives of "normal" children and their teachers ${ }^{20}$ - another reason to approach the issue cautiously.

Even if consensus concerning sound educational practice could somehow be created, the bureaucratic structure of public schooling would inhibit the possibility of radical cliange. ${ }^{21}$ Highly bureaucratized

pears to adopt this view. See, e.g., E. Fruedenderg, Coming of Age in America (1965); C. Silberman, Crisis in the Classroom (1970).

19. See Douglass, The Rights of the Retarded, 23 SYr. L. REv. 1109, 1114-15 (1972).

20. "In order to accomplish anything more extensive than marginal modifications, innovators usually discover they have to alter processes and policies far beyond the specific area with which they are directly concerned." H. KAUfMaN, THE LIMITS of ORganizatTonal Change 88 (1971).

21. The following section borrows from a wealth of material which analyzes organizational behavior. While much of that material either speaks generally about organizations or utilizes the private firm as its model, the approach taken is useful in analyzing school behavior. See generally G. Allison, Essence of DeCision (1971); R. Cyert \& J. March, A Behavioral Thegry of the Firm (1963); A. Downs, Inside BUREAUCRACY (1967); Lindblom, The Science of “Muddling Through," 19 PUB. AD. REV. 79 (1959). For specific discussions of organizational behavior in education see S. Sarason, The Culture of the School and the Problem of Chanoe (1971); Bidwell, The School as a Formal Organization, ORgANIzations HANDBOOK 994 (J. March ed. 1965); Corwin, Education and the Sociology of Complex Organizations, in ON EduCATION 156 (D. Hansen \& J. Gerstl eds. 1967); J. Murphy, Grease the Squeaky Wheel: A Report on the Implementation of Title $\mathrm{V}$ of the Elementary and Secondary 
organizations such as school systems devise routinized ways to handle recurring issues, ${ }^{22}$ and changes in these procedures-what Seymour Sarason refers to as "regularities"23_occur slowly. Only in times of crisis, usually provoked by external events such as court-ordered busing or the election of a reformist school board, are the premises of organizational activity themselves reexamined. ${ }^{24}$

Stability is an organizationally useful attribute. It permits the maintenance of readily understandable and generally accepted school roles: student, teacher, specialist, administrator. It enables those who work in the school to fix expectations of their own and others' behavior. School personnel can count on important things getting done without having to do thein themselves. Stability enables the school to shape, and preserve against outsiders, a culture of its own. Of course, fluctuations and stresses do occur in schools. And roles are determined, at least in part, by how the individuals occupying those roles choose to define them. But the general proposition that the high degree of bureaucratic routinization which characterizes schools is a source of resistance to change appears valid. To the extent that any change threatens existing organizational regularities, it imposes a cost. Change is likely to be implemented, and regularities altered, only if the perception of those who comprise the school organization is that the costs of not changing exceed those inposed by the reform. ${ }^{25}$

\section{B. Organizational Characteristics and the Difficulty of Reform}

The preceding discussion speaks generally of educational pohicy change. But it is possible to develop more precise links between the organizational characteristics of special education and the practices which have evoked critical attention. Limited knowledge is one such characteristic. The response to almost any interesting question concerning the education of the handicapped is either that the answer is unknown or that no generalizable beneficial effect of a given treatunent can be deinonstrated. This lack of knowledge, which is hardly peculiar to

Education Act of 1965, Grants to Strengthen State Departments of Education (1973) (DHEW, grant 05-71-132; published by the Center for Educational Policy Research, Harvard University).

22. [T]he thrust is to routinize, limit uncertainty, increase predictability, and centralize functions and controls. Whether the lure is security, power, growth, or profits, and whether the field is government, industry or welfare, bureaucratization proceeds apace.

C. Perrow, Organizational ANALYsis 67 (1970).

23. S. SARASON, supra note 21, at 62-87.

24. "Change [in bureaucracies] will occur only when external pressure becomes impossible to withstand." M. CrozIER, THe BuREAUCRATIC PHENOMENoN 111 (1964).

25. Cf. P. Blau, The Dynamics of Bureaucracy 263 (1963). 
special education, makes it difficult to predict the consequences of any policy change. Resource limitation is another important characteristic of special education. Special education typically lacks the fiscal capacity needed to perform even those tasks, such as early educational intervention, which it can do well. Finally, the bureaucratic separation of special and regular education into separate subsystems-a demarcation defended and preserved by both-restricts the possibility of collaborative efforts on behalf of children whose status as special or regular students is debatable, and who perhaps could best be served jointly. That separation is not a demarcation of equals. Special programs, at least for the mildly handicapped, often occupy a marginal status in the public school system. A relatively new development, they remain somewhat a stepchild of public schooling. Their resource needs frequently get considered after the regular system's problems are resolved. Special educators, politically unable to assert the autonomy of their programs, often embrace the regular system's understanding of what "special" means; the prograin's purpose emerges, not from independent assessment, but from the pressures that it encounters. The marginal status of special education encourages its personnel to be "conservers," holding onto whatever they have. ${ }^{26}$ It discourages efforts to reconceive the role of special programs-a process that might threaten the dominant school culture. As Burton Clark notes:

A peripheral status will shape administrative ideology, calling for doctrines that will strengthen the organization. Since marginality seeks adjustment beneficial to security here and now, it also demands an administrative ideology that will provide a morally satisfying rationale for these adjustments. ${ }^{27}$

\section{The Severely Handicapped}

To what extent are those special education practices which have drawn critical attention made more comprehensible even justifiable) by relating them to these characteristics? The exclusion of severely handicapped children from the public school structure seems traceable, at least in part, to lack of both pedagogic knowledge and resources. It may well be that all children are educable. But that does not mean that schools know how to provide an education for the severely handicapped. Historically, the function of the public schools has been viewed as training in the three R's. The education of those students who needed a different kind of instruction was left either to

26. For a discussion of "conservers" and other organizational types, see A. Downs, supra note 21 , at 92-112.

27. B. Clark, Adult Education in Transition: A Study of Institutional. INSECURTIX 149 (1958). 
state-run institutions or to the private market. While schools have gradually extended their reach to assume responsibility for harder-toeducate youngsters, the demand that schools provide appropriate education for the severely handicapped calls for nothing less than a redefinition of the institutional knowledge base. For some classes of children, such as the autistic, what is known is so limited that the demand may be quixotic. Moreover, to be effective with severely handicapped children, the school is obliged to educate, socialize, and support their total social environment. The school must link itself to the community, working both to change some aspects of the community and to alter its own traditional mission in order to accommodate more fully the needs and demands of these children's families. Such change blurs distinctions between educational, social welfare, and even criminal justice institutions; it calls upon schools to modify their usual relationship to deviant community members. To the extent that public schools are asked to assume these functions, the traditional structure of public education is severely challenged.

Further, educating the severely lrandicapped is a costly activity which until recently no state educational system had ever wholly assunied. The relative scarcity of special education resources is likely to affect both access to schooling and the scope of what is offered. As presented to a court, the plight of the severely handicapped is straightforward and heart-rending. For that reason, courts are likely to preclude exclusion of these children on the ground of lack of resources. But success in court guarantees neither that the political process will provide additional resources for these children's education nor that the school bureaucracy will reallocate the money it presently receives to fulfill this new assignment. The structural division of education into regular and special instruction makes such reallocation even more unlikely, since the regular system simply has no incentive to surrender any of its resources. These same factors also help to explain why additional special programs for hard-to-educate children are not provided.

\section{The Mildly Handicapped}

\section{a. Misclassification}

The scarcity of special education resources is one notable cause of the misapplication of agreed-upon criteria, the alternate meaning of misclassification. Unable to afford more personnel, the system may have to retain unqualified persons to do assessinents or overburden the professional staff, encouraging it to take short-cuts. ${ }^{28}$ Disputes over the validity of classification criteria are, in part, the consequence of made-

28. See text at note 85 infra. 
quate knowledge concerning the means for distinguishing among students. What skills do standardized tests actually measure? Are culturefree or culture-specific tests more accurate or more useful? These questions have never been satisfactorily answered. Such queries evoke concern when possibly harmful consequences such as misplacement in an inefficacious special program may flow from the wrong choice. Resource constraints also may oblige the schools to utilize such criteria as group rather than individual tests which, in the view of the critics, may be less able to render the fine distinctions of ability and potential that the classification systein calls for. Finally, I.Q. or aptitude tests, the criteria inost frequently employed to sort students, do appear to reflect the cultural biases of the regular curriculum. Inadequate performance on such a test reveals to the regular system that the child should be treated as special. Use of a culturally neutral criterion, while possibly a better gauge of aptitude, yields less useful information to the regular system precisely because of its lack of bias.

\section{b. Differential Vulnerability}

Each of the organizational characteristics of special education renders certain types of students vulnerable to classification as handicapped. Many special programs, developed by highly trained teachers working in a umiversity setting with middle class students, prove of limited utility in public schools. The variety of special problems, the lesser expertise of the school's staff, and the organizational and political problems that inust be addressed render the laboratory-developed techniques ineffective. ${ }^{29}$ School personnel often do not know how to identify the students they can help or how to address the myriad problems encountered by the student and the school.

Resource constraints discourage special program personnel from extending the reach of their competence to all of the children, however labeled, who may need some special lielp. For example, if a child having difficulty in school remains docile in class and does not pose mightmarish problems for the regular classroom teacher, his problems are likely to go undetected until the last years of elementary school, when it is too late for effective intervention. ${ }^{30}$ Resource constraimts also render certain decisions about special program placement budgetary judgments, at least in part. The availability of space or funding for

29. Cf. H. Goldstein, J. Moss \& L. Jordan, The Efficacy of Special Class Training on the Development of Mentally Retarded Children (1965) (Univ. of Illinois Institute for Research on Exceptional Children).

30. But cf. Gotts, Factors Related to Teachers' Irritability in Response to Pupil Classroom Behaviors 1967 (unpublished paper presented at the American Psychological Association Meetings, Washington, D.C.), who reports that extremely passive students may be as trying to the teacher as aggressive students. 
special programs, and not the particular needs of the child, shape the school's inquiry and influence ostensibly pedagogical appraisals. ${ }^{31} \mathrm{Re}-$ source constraints are, of course, a universal lament. No onecertainly no public agency-would admit that it had enough of anything. If such constraints forced the system into making defensible priority judgments, allocating services on the basis of need, they would serve a useful purpose. But the absence of useful knowledge, particularly with respect to children whose handicapping conditions are mild, makes such matching difficult to accomplish. In many cases, given the state of the art, it may not be possible.

The fact that special education is organizationally separate from and marginal to the regular system renders differential vulnerability more likely. Special personnel cannot seek out students on their own. They inust convince the regular teacher that a given child has a problem which can perhaps be alleviated in a special class. Where the regular and special staffs know and trust one another, special personnel can play an important role in identifying and helping youngsters with learning difficulties. But the existence of special prograins for students whose handicaps are not readily apparent, such as the mildly retarded and emotionally disturbed, ${ }^{32}$ discourages such organizational bridges. It is difficult for special personnel to prevent the regular system from referring only children it cannot or will not teach. The apparently limitless elasticity of special programs for those with learning deficiencies or educational handicaps permits the regular system to transfer children who, for whatever reason, create classrooin crises. $^{33}$

The marginal organizational status of special programs fosters cooperation with this system of identification. Some special educators, notably those with a clear sense of their own role, will resist being manipulated in this fashion. But taking the troublesome child out of regular school programs is one service performed by special educators which others in the scliool system can recognize and appreciate. Although school officials may feel that a child whose teacher has in effect rejected

31. See text at notes 296-97 infra.

32. "[N]o single definition of mental subnormality has ever been satisfactory to all concerned." H. Robinson \& N. Robinson, The MENTALly Retarded Caimd 27 (1965).

33. The status quo's defense against such exploitation is the special system's authority to reject children whose test scores are either too high or consistently normal. But such resistance on the part of the special educator is unlikely ultimately to succeed. Since special classes can absorb only a small fraction of crisis-provoking students, the regular administration has only a limited stake in the placement of any particular student. It can simply continue to refer difficult cases until-because of hurried testing, elusive admission criteria or genuine disability-some troublesome students are admitted to the special class. In this way, the existence of special programs for the mildly handicapped enables the regular system to discharge its obligations to those who fare badly in normal school life. 
him is better off in a special class, the matter is probably better dealt with by examining the crisis-provoking behavior of both teacher and student. ${ }^{34}$ Such an examination is unlikely for several reasons: it is timeconsuming and costly; it is anxiety-producing and unlikely to succeed unless the teacher is unusually flexible and the principal willing to assume a truly neutral position in a teacher-student confrontation. Removal decisions should also be appreciated as a tactic meant to ensure survival in the prevailing organizational structure. ${ }^{35}$ The price of survival is, predictably, the differential vulnerability of certain types of students, especially non-whites and boys, to special classification. ${ }^{30}$

\section{c. Efficacy}

Manipulation of school resources appears to have only a limited effect upon achievement for regular as well as special students. ${ }^{37}$ That special programs for the mildly handicapped do not appear to benefit these students more than regular placement is not surprising; it mirrors what is known concerning the limited impact of ability grouping of normal students on achievement. ${ }^{38}$ It is surprising, however, that these special programs, which cost two and three times what regular programs cost, ${ }^{39}$ have survived in the face of their generally conceded inefficacy. Special educators have advanced at least a tenable explanation for this durability. Many of them argue that these students need the protection that smaller, self-contained programs can

34. See N. Kreinberg \& S. Chow, Configurations of Change: The Integration of Mildly Handicapped Children into the Regular Classroom 137-47 (1973) (DHEW, Grant OEG-0-72-4359).

35. In Clark's study of adult education [B. CLARR, supra note 27 at 65], the source of pressure was fluctuating student enrollment; here, pressure appears to stem from the demands of the regular system.

36. Minority overrepresentation seems the clearest illustration of this differential vulnerability to labeling. It is, of course, risky to generalize about the behavior of groups of people, but white, middle class teachers do perceive minority students as different. Minority students may be less accustomed to expectations of public schools and less willing to satisfy those expectations. They may have come to recognize through individual experience and street corner socialization that school offers them little, if anything, of value. The behavior that accompanies such attitudes is likely to pose acute problems for the teacher concerned for classroom order and control, thus promoting the identification of disproportionate numbers of minority students as mildly handicapped.

37. See generally J. Coleman, E. Campaeli, C. Horson, J. McPartzand, A.

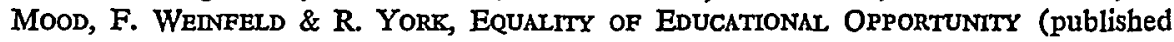
by Office of Education, U.S. Dept. of Health, Edueation and Welfare, 1966); C. JENCKS ET AL., INEQUALTTY (1972); ON EQUALITY OF EDUCATIONAI OPPORTUNITY (F. Mosteller \& D. Moynihan eds. 1972).

38. For a summary of the ability grouping efficacy hiterature, see W. FINDLEY \& M. BRYAN, ABILITY GroupING: 1970 (1971).

39. Johnson, Special Education for the Mentally Handicapped-A Paradox, 29 Exceptional ChiLdRen 62 (1962). 
provide. Some students do indeed require special class attention; for them, regular classes would be a disaster. But the force of the argument for separatisin is blunted by its over-use. The educational efficacy of programs for the mildly handicapped is, at best, undemnonstrated. If, in fact, many special programs offer just smaller classes and respite from the pandemonium of the typical public school, those are benefits to which all children, normal and handicapped, could make legitimate claim.

In resisting the integration of special and regular students, special educators purport to speak for their clientele. But representative advocacy is tricky business since self-interest and chent interest are too closely linked. As the World Health Organization noted two decades ago:

Unless subject to review at fairly regular intervals, protective legislation can easily become self-protective, guarding the right of those with vested interests in one or another category of handicapped persons rather than the persons themselves. ${ }^{40}$

The presence of such vested imterests might better explam why the special programs endure despite their lack of apparent benefit. For both professional and political reasons, efforts to abolish particular categories of exceptionality are often perceived as a threat to the already insecure status of special programs; the proponents of such a policy from the special education ranks are viewed as "turncoats."

\section{d. Permanent Placement}

Why does the label "mildly handicapped" routinely become permanent? The existence of separate organizational structures for regular and special students impedes movement back and forth. The factors which promote initial special class placement-the incapacity of the regular system to develop means of dealing with its deviants, the availability of the separate system to educate such youngsters, and the inadequacy (and misuse) of the criteria for distinguishing normal from special-help to explain the permanence of the placement. Neither the regular nor the special prograin has an incentive to return a special child to the regular program. In the special program, the child is treated as needing help and protection; to the regular program, he is simply a nuisance. As one school district teachers' manual notes:

While the return of special class children to regular classes is seen as a very desirable and legitimate goal, its realization is not always

40. World Health Organization, Legal Considerations of Mental Retardation, in Mental Retardation 106-07 (J. Rothstein ed. 1961).

41. Interview with Al Tudyman, Director of Special Education, Oakland Unified School District, in Oakland, California, March 20, 1973. 
easy. The regular program has, all too often, been relieved to see them leave and has dismissed or ignored provisions for their eventual return. ${ }^{42}$

The fact that the special programs have lower expectations for their students also increases the likelihood that placements will be permanent. All that is usually demanded of the special student is minimal achieve1nent, if not simply acquiescence. If the student does badly, he confirms a prophecy that he is handicapped. For that reason, he is not prodded to do better. The structural separation of special programs permits the development of markedly different curricula to serve what are considered different populations. Even the special student who does admirably falls further and further behind his regular classmates whose schoolwork is considerably more demanding. Since special students are not expected to function normally, and smce the resources and capacity to test that expectation are not readily at hand, reevaluation of these students is infrequent, occurring every two or three years. ${ }^{43}$ By that time, the student may well have become special.

The discussion has traced the tendency of certain organizational characteristics-lack of knowledge, resource scarcity, and structural separation-to influence educational practices. There are, of course, dedicated and technically proficient teachers in special programs who help both organically deficient and emotionally disturbed children and who seek-sometimes successfully-to bridge the gap between special and regular programs. But these results do not flow from the organization of special and regular education; they occur in spite of it.

Yet the lesson to be derived from this discussion is not without ambiguity. Certain attributes of present special education programs militate against productive change. Some proposed changes may be unfeasible and others threatening to the existing structure of special programs; still others are simply unwise. But changes have occurred. Fifty years ago, there were no school-based special programs. Those students now considered to be mildly handicapped were either accepted as slow but normal or were demed access to the schools. Although this Article notes the rigidity of special programs, there are successful instances of ventures which combine special and regular classes, removing the global labels that the prevailing system imposes. ${ }^{44}$ In

42. Department of Special Education, Oakiand [California] Public Schools, HANDBOOK FOR TEACHERS AND ADMINISTRATORS OF Programs FOR EDUCATIONALly HANDICAPPED PUPIIS 27 (1971).

43. Cf. Feuerstein, A Dynamic Approach to the Causation, Prevention, and Alleviation of Retarded Performance, in Sociocultural ASPECTS OF MENTAL RETARDATION 341 (H. Haywood ed. 1970).

44. See K. BeEry, Models for Mainstreaming (1971); New Directions in SPecial Education (R. Jones ed. 1970). 
short, change can and has occurred in the education of the handicapped. But how is such change likely to come about?

\section{Special Education and the Law}

In the viewpoint of some spokesmen, legal intervention may be the most effective means to secure change in the education of handicapped children. Psychologist Burton Blatt, for example, has stated: "More and more I coinprehend the powerful positive influence that lawyers, if not laws themselves, now exert within my field of work . . . [Lawyers are] heroes, even now, to some of us today." 45 It is tempting, especially for lawyers, to view those who have initiated litigation and pressed for legislative change as the new heroes of the handicapped. But is that view correct? Before exploring the three case studies and the utility of due process in school classification, a brief description of current law reform efforts is in order.

Recent court decisions and legislative efforts have focused on several quite different aspects of the problein of educating handicapped children. Two decisions sought to secure for the severely handicapped more-and more appropriate-educational services. In Pennsylvania Association for Retarded Children v. Commonwealth of Pennsylvania ${ }^{46}$ discussed in the first case study, a three-judge federal court ratified a consent agreement assuring all retarded children the right to publicly supported schooling "appropriate" to their needs. A similar result was reached in Mills $v$. Board of Education, ${ }^{47}$ which extended the right to all students previously denied the benefits of an education. Mills and its aftermath are treated in the second case study.

Courts have also inquired into the overrepresentation of minority students in classes for the mildly handicapped. In Larry P. v. Riles, ${ }^{47 a}$ the district court concluded that the I.Q. tests which formed the basis for special placement were incapable of measuring the intellectual capacity of black students, and temporarily enjoined the use of such tests to assign black students to classes for the educable mentally retarded. Several consent decrees, designed to protect Mexican-American children from placement in programs for the retarded on the basis of their performance on English language tests, have reached similar results. ${ }^{48}$

45. Blatt, The Legal Rights of the Mentally Retarded, 23 SYR. L. REv. 991, $992-93$ (1972).

46. 343 F. Supp. 279 (E.D. Pa. 1972).

47. 348 F. Supp. 866 (D.D.C. 1972).

47a. 343 F. Supp. 1306 (N.D. Cal. 1972). See generally Murdock, Civil Rights of the Mentally Retarded: Some Critical Issues, 48 NOTRE DAME LAWxeR 133 (1972).

48. See, e.g., Diana v. State Bd. of Educ., No. C-70-37 (N.D. Cal., July, , 1970) (consent decree); Guadalupe Organization v. Tempe Elementary School Dist. No. 3, No. 71-435 (D. Ariz., Jan. 24, 1972) (consent decree). The pleadings in 
Judicial decisions have also sought to establish a rational procedural framework for making individual classification decisions. Both the P.A.R.C. and Mills decrees require that placement in classes for the handicapped be preceded by a formal due process hearing, if the parent opposes the proposed assignment. Legislation in several states, mcluding Massachusetts, has imposed a similar framework. ${ }^{40}$ The third case study, which focuses on California legislation, assesses the consequences of one sucli endeavor.

Each of these undertakings responds directly to one or more of the criticisms of present practice discussed in this Part. But to the extent that they fail sufficiently to take into account the organizational factors which appear to have prompted the emergence of the practice, their effect may be more hortatory than real. And each change is likely to impose new costs-diversions of time, nnoney and energynot fully anticipated by their proponents. ${ }^{50}$

The numerous organizational barriers to change discussed earlier require that the claims of the lawyer-reformer should be viewed skeptically. If the promise of law reform is fulfilled, it may well benefit exceptional children by imposing at least formal rationality on scliool decision-inaking practices, by providing leretofore excluded children with some educational services, and by provoking more publicity and greater appearance of change than have the efforts of other critics. But the ways in which both regular and special children should best be educated will depend ultimately on the resources at hand and upon the knowledge, good will, and organizational capability to use those resources wisely. Questions concerning the education of exceptional children have been with us for a long time. They are unlikely soon to receive definitive answers, and it is even more unlikely that such answers will come solely or even primarily from court decisions and legislation.

The following case studies do not atteinpt anything approaching a rigorous assessment of the impact of legal change on the behavior of school organizations. Rather, more simply, they explore recent developments in special education in three quite different places. Although they do not form a neatly coherent umit or a representative sample,

these and similar cases are collected in HARVARD UNTVERSTTY CENTER FOR LAW \& EDUcation, Classification Materials (1973).

49. See note 344 and text at notes 367-68 infra.

50. [A]ny attempt to eliminate an existing social structure without providing adequate alternative structures for fulfilling the functions previously fulfilled by the abolished organization is doomed to failure ... To seek social change without due recognition of the manifest and latent functions performed by the social organization undergoing change, is to indulge in social ritual rather than social engineering.

R. Merton, SOCial Theory and Social Structure 81 (revised ed. 1957). 
the case studies, chosen because of their apparent legal significance, do shed light on one another. Two of them, P.A.R.C. and Mills, focus on major court decisions which mandated both substantive and procedural changes in the education of the severely handicapped. The third discusses California's experience with legislation designed to secure certain procedural safeguards to those subject to placement in special classes.

Even preliminary assessment of the impact of legal reforni on special education is a hazardous enterprise. The nature of impact clearly varies with the particular legal reform. Abolishing the practice of excluding severely handicapped students and insisting that they be provided with an appropriate or suitable education, as P.A.R.C. and Mills do, seems to require reordering of resource priorities and may also necessitate structural change in the sclool organization. Insisting upon procedural regularity, as P.A.R.C., Mills, and the California legislation all do, requires the elaboration and defense of formal standards of placement; it makes it harder for the regular system's intuitive sense of who is exceptional to prevail. For the lawyer, procedural and substantive approaches may be linked, as they are in P.A.R.C. and Mills, but the consequences of each kind of change need to be disentangled if they are to be understood.

The effect of a given reform may well vary from place to place. Parental pressure for change may be strong (as in Pennsylvania) or weak (as in Washington), sporadic or sustained; the school's (or school system's) willinguess to change will vary. In some places, a particular legal mandate may be seized upon by reformers within the school strucure.

To talk about the effect of "law" quite deliberately inerges judicial and legislative efforts. Historically, the two have been distinguished, and quite properly. ${ }^{51}$ The justification for judicial and legislative intervention differ. Legislatures exercise direct command over resources and the option repeatedly to review earlier actions, two powers unavailable to courts. Certain decisions inay also acquire greater political legitimacy if made by legislatures. Yet from the school system's point of view, both courts and legislatures are outsiders and each may seem equally unaware of the real problems which schools encounter.

Finally, what one might mean by "effect" is unclear. One way to assess what has happened is to consider whether the letter of the legal mandate has been complied with: Have the districts attempted to

51. For discussions of judicial impact see $S$. WASBX, THE IMPACT OF THE UNTED States Supreme Court: Some Perspectives (1970); The Impact of Supreme CoURT Decisions (T. Becker ed, 1973). 
locate all previously excluded students? Do California school districts formally review each recommended special placement? But those who sought change also had broader goals in mind: Has Washimgton, D.C. taken seriously its obligation to develop "suitable" placements for all students and not assumed that existing programs were necessarily appropriate? Are California placement decisions now made with collective thoughtfulness, not merely perfunctorily? Compliance with both the letter and the spirit of legal reform merit consideration.

The conclusions of the case studies should be appraised cautiously. They were conducted over a period of several months, long enough only to begin to understand what the difficult questions really are. The Pennsylvania and Washington, D.C. studies analyze the period iminediately following court decisions and thus cannot identify long-term and possibly more significant effects. At points, important factual material proved unavailable. Yet the case studies do provide some insight into the relationship between organizational attributes and legally mandated change. They also give some structure to the speculations in Part III concerning the utility of procedure as a means of improving existing classification decision-making.

II

Legal Mandates and Organizational Change: Three Case Studies

A. Pennsylvania Association for Retarded Children v. Commonwealth of Pennsylvania ${ }^{52}$

For many years Pennsylvania has required that all children between the ages of eight and 17 attend school. ${ }^{53}$ However, any child judged by a school psychologist to be "unable to profit from further school attandance"54 or "ineducable and untrainable" w5 was excused -or, more accurately, excluded-froin the public schools. In operation, these provisions doomed severely retarded children to institutions providing little, if any, education, ${ }^{56}$ or to the backrooms or attics of their homes.

52. 343 F. Supp. 279 (E.D. Pa. 1972).

Field research for this section was conducted between November 1972 and July 1973. The researchers imterviewed state education officers, parent organization officials, the court-appointed Masters, administrators, school psychologists and special education personnel in six districts. Where the source of information is not indicated, the information could not have been used if the source had not remained confidential.

The authors are currently undertaking a three-year assignment of the effeets of the Pennsylvania decree at the state, school district and local levels.

The final phase of research for this section was partially supported by grant NE-G00-3-0192 from the National Institute of Educatiou.

53. Pa. Stat. AnN. ch. 24, \& 13-1326 (1962).

54. Id. $\$ 13-1330$ (Supp. 1973).

55. Id. § 13-1375 (Supp. 1973).

56. Pennsylvania Ass'n for Retarded Children v. Commonwealth, 343 F. Supp. 279 
In 1971, the Pennsylvania Association for Retarded Children (PARC), long involved in problems of the retarded, filed suit challenging the constitutionality of excluding severely retarded children from school. While PARC had been active in a host of issues concerning the retarded, litigation was a novel approach for the organization. Two years before the suit was filed, Thomas K. Gilhool, the the Philadelphia attorney who ultimately argued the case, first suggested the tactic: "Litigation is one role among many, whereby the Association may encourage and expedite the kind of change it seeks in the care and treatment of retarded children.957

P.A.R.C. was a seminal suit. It asserted that Pennsylvania's failure to offer any education to severely retarded children represented a denial of equal protection, and that assignment of youngsters to programs for the retarded, unless preceded by notice and the opportunity for a hearing, denied thein due process of law. While both claims were legally novel, the three-judge federal district court never had to rule on the merits of the constitutional claims. In October 1971, after several hearings before the court, the suit was tentatively settled. The settlement was ratified in May 1972.58

P.A.R.C. mandates sweeping changes in the education of the retarded. It requires that the state locate and identify all excluded youngsters; that local districts undertake thorough medical and psychological evaluation of previously excluded children, of children presently in classes for the retarded, and of children recommended for such classes; ${ }^{50}$ and that all children in special classes automatically be reevaluated every two years (the old statute called for reevaluation every three years or every year on parental deniand) and any time a change in childrens' programs is contemplated ${ }^{60}$ Finally, P.A.R.C. required that all retarded children be placed in a "free public program of education and training appropriate to the child's capacity." ${ }^{\prime 61}$ While the consent agreenent did not specifically define appropriateness, it did declare that regular class placement was "preferable" to placement in any

(E.D. $\mathrm{Pa} .1972$ ) [hereinafter cited as P.A.R.C.]. Of the 4,519 children of school age in Pennsylvania institutions, at the time of the suit, 100 were in a full education and training program, 1,700 were in partial but inadequate programs, and 3,259 received no education program. Id. at 296.

57. L. IIPpMan and I. Goldberg, Rught to Education: AN ANatomy of the Pennsylvania CASE AND ITS Implications for CHILDRen 20 (1973) [hereinafter cited as RIGHT to EDUCATION].

58. Because the court was asked only to ratify the consent decree it did not reach the merits of the constitutional claims. Rather, the court concluded that they were constitutionally "colorable." 343 F. Supp. at 295, 297.

59. Id. at 315.

60. Id. at 303,315 .

61. Id. at 285 . 
other kind of program. ${ }^{62}$ Parents dissatisfied with the school district's placement recommendation were given the right to a hearing before an impartial hearing officer. ${ }^{63}$ To oversee the decision, the court appointed two masters: Dennis Haggerty, an attorney in Philadelphia and a former PARC officer, and Doctor Herbert Goldstein, a professor of Special Education at Yeshiva University in New York City. ${ }^{\text {a }}{ }^{4}$ The P.A.R.C. decree was headline news across the country. Immediately after the tentative consent agreement was announced, Governor Milton J. Shapp, a progressive Democrat strongly committed to the enterprise, appeared at a press conference with PARC officials to endorse it. He also made numerous spot announcements on television and radio to explaim the scope of the decision. The New York Times called the decision "a historic step in an area that suffered from public and professional neglect." 05 The National Association for Retarded Children and the Council for Exceptional Children goaded their membership to imitation. A book analyzing the significance of the case was rushed into primt. ${ }^{6 B}$

\section{Implementation of P.A.R.C.}

Once the decree was finally approved on May 5, 1972, Governor Shapp created a Right to Education Office, federally funded on a oneyear renewable basis, to oversee the implementation of the consent agreement. But even with the help of a statewide agency, implementing P.A.R.C. has proved extremely difficult. ${ }^{67}$ It has demanded an enormous expenditure of effort and dollars to identify, evaluate, and place previously excluded youngsters and to reevaluate the retarded children presently in schools. The indeterminate size of the class (estimates ranged between 70,000 and 100,000$)^{18}$ as well as lack of agree-

62. Id. at 307 .

63. Id. at 303-05. An indeterminate group of children residing in state schools and hospitals were left to the care of the Department of Public Welfare, which also was charged with providing "appropriate" education under the supervision of the Department of Education. Id. at 312-13.

64. Id. at 314.

65. N.Y. Times, Oct. 13,1971 , at 44 , col. 1 .

66. RIGHT To EDUCATION, supra note 57.

67. Thomas K. Gilhool, PARC's lawyer, was well aware of this fact. Shortly after the decree, he "quickly warned his chients that court decisions are no more selfenforcing than are statutes. A court order will require follow-up by interested parties." RIGHT to EDUCaTion, supra note 57, at 46.

68. During the identification period, estimates of the size of both the previously excluded group and the entire class of children fluctuated enormously. PARC literature estimated that there were 100,000 retarded children in the state. The Sparc (Philadelphia Association for Retarded Children Newsletter, Special Childhood Issue) (Spring, 1973). Since the best State Department of Education estimates put the number of retarded children in school at 50,000, PARC expected to find as many as 50,000 excluded children. In January, 1973, Tom Gilhool stated that the best estimate 
ment as to the characteristics of the excluded group compounded the problem. Also, as Robert Burt has noted: "[T] he federal court did not resolve a dispute between contesting parties, but instead ratified an agreement between advocates for children services and professional service agencies to raid state treasuries for greater funds on behalf of their shared clientele." no one knew just what additional resources were needed, where they should be located and who should assume responsibility for administering them.

\section{a. Identification}

The consent decree demanded that first priority be given to finding excluded youngsters. The Right to Education Office sought out children in ingenious ways. Through COMPILE (Commonwealth Plan for Identification, Location and Evaluation of Mentally Retarded Children), ${ }^{70}$ it arranged to place notices in all state liquor store packages and welfare checks, send letters hoine with all school children, publish regular announcements in at least one local newspaper in each area of the state, and establish a toll-free phone service through which anyone might report the existence of an excluded child. All school districts as well as all state agencies dealing with school-age children were required to search their records for youngsters who were not enrolled in sone educational program. To ascertain the accuracy of the identification process, COMPILE called for a door-to-door census in three representative school districts (urban, suburban and rural). Simultaneously, PARC itself organized a parallel undertaking, "Operation Childhunt," turning over to the Right to Education Office the names that it uncovered. ${ }^{71}$

The identification process generally went well, but not without hitches. The most noteworthy noncompliance occurred in Philadelphia. School administrators there claimed to have completed their en-

was 25,000. [Gilhool, The Uses of Litigation: The Right of Retarded Children to a Free Public Education, 50 PEABody J. OF Educ. 123 (1973).] Such figures were based on school census data as well as on projections based on an expectation that approximately 5 percent of the population falls, by statistical definition, below the state mandated criterion (I.Q. 75) for admission to special education.

69. Burt, Beyond the Right to Treatnent: Strategies for Judicial Action to Aid the Retarded (report prepared for the President's Commission on Mental Retardation and the Project on the Classification of Exceptional Children, Vanderbilt University).

70. Pa. Dep'ts of Educ. and Pub. Welfare, Compile: Commonwealth Plan for Identification, Location, and Evaluation of Mentally Retarded Camldren, 1972 [hereinafter cited as COMPILE].

71. PARC developed a list of approximately 20,000 pupils. Most of these overlapped with those found through COMPILE. Interview with Marhene Snoker, Assistant Director of PARC, in Harrisburg, Pa., June 28, 1973. 
tire search in one week, prior to the development of COMPILE. ${ }^{72}$ In a lengthy rebuttal the Masters found Philadelphia in wilful noncompliance, determined that Philadelphia officials had no intention of making a serious effort to comply, and asked the court to order them to do so. ${ }^{73}$ Their strong stand led to several meetings among the litigants and, in December 1972, to the submission of a plan acceptible to all parties. By February 1973, a full year after the deadline, the Masters were finally satisfied that Philadelphia was taking positive steps toward compliance. ${ }^{74}$

Only slightly less serious were the problems of implementing COMPILE in the state scliools and hospitals. By August 1972-seven months after the judicially established deadline for initial screening had passed-the State Department of Public Welfare (DPW) had not provided the Right to Education Office with any data about institutionalized children. The Masters attributed the delay to the problems of inter-agency cooperation and begged the court's indulgence. ${ }^{75}$ By November 1972, the Masters had grown impatient. Although they still lad no accurate data, they estimated that at least thirty percent of the children in state schools and hospitals were receiving no education, while the remaining seventy percent were receiving only one to five hours each week. The Masters asked the court to order the Department of Public Welfare to complete COMPILE by January 2, $1973 .^{70}$ Before the court acted, the Department of Public Welfare met the deadline, although as late as June 1973, 200 children in Allentown State Hospital still had not been screened. 77

There is general agreement among the interested parties that the vast majority of previously excluded children liave been found. The

72. Stipulation of Facts Concerning Compliance by Co-defendant School District of Philadelphia (filed Aug. 1, 1972), P.A.R.C., 343 F. Supp. 279 (E.D. Pa. 1972).

73. First and Interim Report of the Masters at 69 (filed Aug. 2, 1973), P.A.R.C., 343 F. Supp. 279 (E.D. Pa. 1972) [heremafter cited as First Report].

74. Third and Interim Report of the Masters at 2 (filed Mar. 9, 1973), P.A.R.C., 343 F. Supp. 279 (E.D. Pa. 1972) [hereinafter cited as Third Report].

75. First Report, supra note 73, at 2-3.

76. Second and Interim Report of the Masters at 2 (filed Nov. 19, 1972), P.A.R.C., 343 F. Supp. 279 (E.D. Pa. 1972) [hereinafter referred to as Second Report].

77. Presentation of Gary Makuch, Dep't of Public Welfare representative, Masters Hearing, June 12, 1973. [Transcripts of the Masters Hearings on this and other dates cited below are on file at the Right to Education Office (REO) in Harrisburg, Pa., and with Peter Kuriloff.] The Commonwealth of Pennsylvania distinguishes between "state schools and hospitals," which are primarily for the retarded, and state hospitals, which are primarily for the mentally ill. Nevertheless, COMPILE calls for the identification of all children who possibly might be retarded. The process by which these leads are then assessed to determine which are false and which merit further extensive evaluation is referred to as "screening." Since the operational criteria for admission to state institutions has never been especially well related to diagnosis, the 200 children in Allentown State Hospital should have been screened. 
rural and suburban census turned up less than a dozen children who had been missed by Childhunt and COMPILE. ${ }^{78}$ By April 25, 1973, COMPILE had identified approximately 19,000 children as possibly retarded. Of these, about 4,000 were found not to be retarded, and of the remaining 15,000 , only 7,398 were excluded from any program of education-far fewer than either PARC or the Commonwealth had anticipated. Of the $7,398,2,571$ were severely and profoundly retarded and had never been in any program; another 1,227 were in private licensed facilities providing interim care as they awaited admission to state schools. Finally, 3,600 were in state schools and hospitals. ${ }^{79}$

These figures indicate the success of the identification processa success made possible by the commitment of inost of Pennsylvamia's public officials, the prodding of the Masters, the energetic program of PARC and, perhaps, by the fact that the goal was concrete and easily understood.

\section{b. Evaluation}

The P.A.R.C. decree mandated that all excluded children be evaluated and appropriately placed by Septennber 1, 1972, a timetable which in many districts proved infeasible. Over 60,000 children had to be evaluated or reevaluated by procedures which were much more complicated and elaborate than they had been prior to P.A.R.C. It now takes approximately four-and-one-lialf to five hours for the evaluation of each child. A conservative 'estimate thus suggests that each Pennsylvania school psychologist spent between 350 and 400 hours simply doing the assessments required by COMPILE. ${ }^{80}$ Overwhelmed by these new deinands, they often found classroom

78. The urban census was the subject of a political battle between the State Department of Education and the Pittsburgh School Board and did not get underway until June, 1973. Interview of Peter Kuriloff with Joseph Lantzer, Director of REO, in Harrisburg, Pa., May 8, 1973. See also Masters Hearings, Dec. 12, 1972, and Jan. 16, 1973.

79. Telephone interview of Peter Kuriloff with William Benson, Area coordinator of REO, Apr. 28, 1973. The figures are derived from a computer printout data sheet on file in the REO office and represent the most accurate picture available as of April 25, 1973. In this regard, it is interesting that the office was not able to break down the data further so as to show how many of the previously excluded children are now classified as educable, trainable, profound, etc. It is perhaps indicative of the organizational obstacles to successful P.A.R.C. implementation that the state office in charge of overseeing it has not developed, by mid-1973, information vital to that enterprise.

80. These estimates were arrived at as follows: P.A.R.C. required that elaborate reevaluations be carried out on at least half of the 51,000 retarded children in school. It also required that the 10,000 new retarded childreu (including 7,398 previously excluded children) be evaluated. Interviews conducted by REO Regional Representative Jerry Hearsum with 47 of the approximately 400 psychologists in the state educa- 
space for children first and evaluated them when time permitted. Children previously assigned to classes for the retarded remained there until reassessments could be made. ${ }^{81}$ By January 1973, most of the evaluations had been done in all areas of the state except Philadelphia. Most districts had also started the reevaluations. Philadelphia, openly resistant through 1972 and then plagued by strikes and fiscal crises, did not begin to complete its obligations under COMPILE until the spring of 1973.

In an effort to avoid the all-too-common, simplistic diagnoses (which often said little more than "Janet is a cute, lovable, but slow child"), COMPILE requested that evaluations include information concerning a wide variety of behavorial characteristics. It called for psychological testing using the "most valid and reliable instruments generally recognized by the profession,"82 a review of the child's educational status (if he was in school), an inquiry into the child's family history to determine how well he coped outside of school, and a medical examination.

Such a multi-faceted inquiry was essential to develop what COMPILE called "a continuing diagnostic prescriptive and psychoeducational plan."83 But because it might involve a pliysician, a psychiatrist, a neurologist, a public health nurse, a social worker, and a speech therapist, annong others, the evaluation was time-consuming, and required extensive managerial skill by the coordinating school psychologist. Its implementation depended on the willingness of the school organization to make available the resources necessary to accomplish the evaluation and to make use of the evaluation in devising program placements.

The ability of the individual psychologist undertaking the evaluation was also of critical importance. The school psychologist selects the test instruments, determines who will take part in assessing the child's difficulties, and decides whether to perform all of the recom-

tion system, representing 26 intermediate units, indicate that approximately 4.5 hours were required to carry out each assessment. Thus, $(25,500+10,000 \times 4.5) \div 400=$ 399.4 hours per school psychologist. Presentation of Jerry Hearsum, REO Regional Representative, Masters Hearing, June 12, 1973.

81. These findings, and those presented infra on the impact of $P A R C$ at the district level, are based on Peter Kuriloff's interviews with administrators, school psychologists, and teachers in Philadelphia and five of its suburbs. (Notes on file with Peter Kuriloff-) As such, they only are indicative of what is happening in the most populous area of the state and only are suggestive of what may be going on in other areas. Getting the latter data was beyond the resources of this inquiry, in that it would have required extensive interview and survey techniques in a representative sample of districts. Neither was it available from the transcripts of the Masters Heariugs since these tended to focus on the broader problems of impleinentation.

82. Compile, supra note 70 , at 8 .

83. Id. at 9. 
mended evaluative procedures. When conducted by a harassed psychologist-and after P.A.R.C. almost all Pennsylvania school psychologists were harassed - the ideal evaluation sometimes gave way to hasty processing. In districts with large numbers of previously excluded children, time, personnel, and resources were too limited to translate COMPILE's demands for prescriptive evaluation into effective practice.

Other factors have impaired the quality of evaluations. While P.A.R.C. requires that all children placed in programs for the retarded be reevaluated much more thoroughly than previously, the demands of assessing children who had never been evaluated for public school placement encouraged routine affirmation of prior decisions. In one probably not atypical district a psychologist filled out reevaluation forms by copying information from old evaluations. This practice is particularly questionable in light of research findings indicating that substantial numbers of children in the five-county, greater-Philadelphia area have in fact been misclassified as retarded. ${ }^{84}$

Organizational pressures also played a role in distorting the quality of evaluation. In districts anxious to maintain high enrollments in classes for the retarded-and thus maintain their levels of state aid- ${ }^{85}$ psychologists were pressured to test children with instruments such as the Stanford-Binet which characteristically yield lower scores than other I.Q. tests. ${ }^{88}$ One director of pupil personnel services expressed the hope that such an approach would "keep these children where they are and avoid stirring up their parents."

But even in the vast majority of cases where the psychologists performed in a professional inanner, they have seriously criticized the 14page, "Commonwealth Riglit-to-Education Evaluation Form"s7 they are required to fill out in addition to any reports they write based on

84. See Garrison \& Hammill, Who Are the Retarded?, 38 ExCEPTIONAL CHILDREN 13 (1971).

85. School districts in Pennsylvania are required to spend an amount equal to their average yearly per-pupil expenditure on their handicapped children. The difference between that figure and what it actually costs to educate them is borne by the state. Dep't of Education, Commonwealth of Pa., Harrisburg, Pa., Supplement Three: School Laws of Pennsylvania (Cumulative Annual Supplement for use in 1973) \& 2508, at 18-19.

86. Clever psychologists can play this game too. One director of special education described how she and her fellow psychologists used to use instruments which produced low scores whenever they had a child who desperately needed special placement and the only ones available were EMR and TMR classes. Conversely, she stated that now most psychologists she knows refuse to label a child retarded on the basis of one score from any instrument. Interview of Peter Kuriloff with Elizabeth Long, Director of Special Education for William Peun School Dist, Yeadon, Pa., in Yeadon, Apr. 9, 1973.

87. Commonweatth of Pa., Right to Education OfFice, Right-to-Education Evaluation Form (DEBE-1051) May, 1972. 
the tests they administer. They have found the scales contained in the form inappropriate for profoundly retarded children-the very children most likely to have been excluded. Many psychologists believe that the standards for evaluation themselves are not adequate. More important, the standards do not protect against evaluation practices which reflect the schools' limited resources and organizational pressures.

\section{c. "Appropriate" Placement}

The P.A.R.C. consent agreement required Pennsylvania to submit to the Masters a plan specifying

the range of programs of education and training, their kind and number necessary to provide an appropriate program of education and training to all mentally retarded children, where they shall be conducted, arrangements for their financing, and, if additional teachers are found to be necessary, recruitment, hiring and training arrangements. ${ }^{88}$

COMPET (the Commonwealth Plan to Educate and Train Mentally Retarded Children), ${ }^{89}$ which the state published in the late Summer of 1972, does not meet the consent agreement's requirements. As one PARC official pointed out, it does not specify a full range of progranıs; the kind and number of classes; the location of the classes; the arrangements for funding them; the standards, methods of recruiting, and training of teachers; and the standards for the curricula of various prograins. ${ }^{90}$ It is, mstead, what one critic called a "cook book version of a curriculum guide," range of retarded children. ${ }^{92}$ For the state to produce a curriculum for exceptional children before figuring out where the curriculum might be used is to put the pedogogical cart before the organizational horse. As Jaines Gallagher, an expert in the field of special education, commented:

An extensive curriculum such as presented here [in COMPET] is useful only after one has settled where and under what circumstances the child is going to receive that curriculum. . . . The crucial elements of planning, namely, precisely what is going to be done to whom under what set of circumstances, still remain something

88. 343 F. Supp. at 315.

89. Pa. Dep'ts of Educ. and Pub. Welfare, Compet: Commonwealth Plan for EDUCation and Trainino of Mentally Retarded ChILdRen (1972) Thereinafter cited as COMPET].

90. Id. at 166-67.

91. Letter from John A. Abbruzzese, Jr., to Dr. William F. Ortman, Director, Bureau of Special Education, Aug. 30, 1972, in id. at 176.

92. COMPET, passim, discusses everything from teaching a child to raise his head in a coordinated manner to developing good judginent and reasoning at common șense situations, 
of a mystery. Even more so are budget estimates of what additional resources will be needed to carry out these intentions. ${ }^{93}$

While COMPET's shortcomings may be attributed im part to the three-month completion deadline imposed by court orders, restricting the plan to a narrow discussion of curricula may have been designed to avoid the ticklish "appropriate" education-cost/manpower trade-off problems with which the consent decree itself had not reckoned. ${ }^{94}$

COMPET ignores the most basic implementation question: will an "appropriate" education be provided for all retarded Pennsylvania children? To insist that each child receive "appropriate" instruction threatens the organizational status quo. Special educators and program administrators often handle this threat by denying it, giving rise to claims frequently heard in field interviews to the effect that P.A.R.C. has had little impact "because we've been doing it all along anyway." "95 Yet "appropriate" does not necessarily mean more of the same; organizational rigidity is not a justification for lack of educational alternatives. In order to understand the impact of such a standard on existing school practices, a brief description of Pennsylvania's pre-P.A.R.C. special education programs is needed.

In Pennsylvania (and many other states) the multiplication of special programs has been taken as a sign of pedagogical progress. State funds pay for most of these programs, including classes for the educable and trainable mentally retarded, the physically handicapped, the brain injured, and the socially and emotionally maladjusted. ${ }^{96}$ Special educators generally regard such programs as exhausting the range of "appropriate" placements and view their task as determining which is best suited to a given child. The categories themselves usually remain unquestioned, even in those districts which dramatically increased their special education budgets in order to accommodate previously excluded children. ${ }^{97}$

93. Letter from James J. Gallagher, Director, Frank Porter Graham Child Development Center, University of North Carolina to Peter P. Pollom, Executive Director, PARC, Aug. 25, 1972, in COMPET, supra note 89, at 168.

94. Second Report, supra note 76. The Masters recognized that COMPET is a tentative document to be revised in light of the 1972-73 school year experiences. In the spring of 1973, the Masters appointed an evaluation team to review COMPET and to recommend appropriate revisions.

95. In the field interviews this was heard several times, once from a highly respected associate superintendent of schools whose area of responsibility included special education.

96. See Pa. Stat. ANN. ch. 24, §§ 13-1373, 25-2509 to -2509.1 (Supp. 1973).

97. The Delaware County Intermediate Unit adopted a special education budget for 1972-73 of $\$ 3.3$ nillion, an increase of 28 percent over the previous year. Because PARC expenditures do not have their own line in the budget, it was not possible to determine low much of this was spent on expanding existing programs or developing new ones. Telephone interview of Peter Kuriloff with Dr. Laura W. Murphy, Director of Special Education, Delaware County Intermediate Unit, Mar. 27, 1973. 
P.A.R.C. did not necessarily endorse the status quo as the preferred solution, but neither the decree nor COMPET provided alternatives. In some districts the short-term outcome appears to have been noncompliance or foot-dragging resistance. Philadelphia has barely begun to institute COMPET. When the district failed to heed the order of the Masters to do so in the summer of 1972, PARC itself went back to the court in late August. The court ordered Philadelphia to comply by September 1 -an admittedly unrealistic demand. In October PARC went to court again, and this time the school district was ordered to prepare an acceptable plan for implementation by January $2,1973 .{ }^{98}$ A political dispute in Pittsburgh led the city to refuse to undertake a census of school-age children. The district reopened abandoned schoolhouses for previously excluded children. As one PARC official commented, "The city went out of its way to treat these students as second class citizens." Pittsburgh also tried to use its school disciplinary code as a vehicle for continuing the exclusion of two children it had evaluated under COMPILE. This situation was resolved by the Masters, who got the children readmitted through arbitration and then sought an Attorney General's Opinion which forbade all school districts from using disciplinary codes to exclude retarded children. ${ }^{99}$

A more complicated issue of compliance arose in regard to the provision of appropriate education to children in state schools and hospitals. Under the terms of the consent agreement, the educational program was to be provided by the Department of Public Welfare under the supervision of the Department of Education. This arrangement created serious organizational and financial problems. The Department of Public Welfare reeeived no additional money to cover the initial costs of the program. Only by taking funds away from other programs was the Department able to scrape up approximately a half-million dollars for this purpose. Because state facilities were already overcrowded, understaffed, and underfinanced, there was little leeway for creative implementation. By February 1973, however, the Department had agreed to make 1,950 new staff positions available, ${ }^{100}$ of which 1,550 were to be used to provide education in current state schools and hospitals, and 250 to staff a soon-to-be-opened institution. ${ }^{101}$ These positions were to paid for out of a proposed-but as of yet, not obtained-Department of Public Welfare budget increase of 47 million dollars. ${ }^{102}$

98. Order (filed June 15, 1973), P.A.R.C., 343 F. Supp. 279 (E.D. Pa. 1972).

99. First Report, supra note 73, at 2.

100. Third Report, supra note 74.

101. Id.

102. Philadelphia Inquirer, Feb. 13, 1973, at 6-C, col. 1. This proposal en- 
A more subtle but still serious organizational difficulty was created by an administratively sensible agreement, worked out between the state Departments of Public Welfare and Education, that programs sponsored by the Department of Public Welfare were to be supervised by the Department of Education. For years state school and lospital employees liad been caring for children the schools had rejected as ineducable. This widely held notion of ineducability had led the Department of Public Welfare to hire unskilled paraprofessionals to provide care for the "hopeless cases" residing in state schools and lospitals. ${ }^{103}$ The agreeinent meant that people who were only marginally competent suddenly found themselves considered educators under the supervision of schools which had only recently rejected the children to be educated, a situation which created antagonisms. ${ }^{104}$ The need for the Department of Public Welfare to develop expertise already possessed by the educational establishment made the gap between the professional competence of educators and hospital workers inore explicit, and tensions further increased. ${ }^{105}$ At the prodding of the Masters, representatives of the schools and the state hospitals began a series of meetings in spring of 1973 which resulted in an agreement im principle to divide responsibility for providing education to the hospitalized children. ${ }^{106}$ Under the agreement, the Department of Public Welfare provides funds for the programs which the Department of Education staffs and runs. ${ }^{107}$

The relationship between the Departments of Education and Welfare also becanie a problem in securing compliance with P.A.R.C. standards by private licensed facilities and private licensed schools. Private licensed facilities operate under license from the Department of Public Welfare to provide interim care for children waiting to get into state hospitals. The standards for licensing are minimal, involving

countered the typical legislative difficulty that funds for retarded children (and other Department of Public Welfare programs) often are the first trimmed in a search for fiscal responsibility. Cuts forced the reduction of these positions and have prevented the opening of the new state school.

103. One authority believes that special education has operated for years under an "inverse law" such that the more handicapped the child, the less coinpetence the teacher who worked with him was thought to need. Interview of Peter Kuriloff with Dr. Herbert Goldstein, in Philadelphia, Pa., June 11, 1973.

104. Interview of Peter Kuriloff with Dennis Haggerty, P.A.R.C. Master, in Philadelphia, Pa., May 8, 1973.

105. Presentation of Gary Makuch, Dep't of Public Welfare representative, Masters Hearing, July 10, 1973 (progress report on the transfer of responsibility for the education of children in state schools and hospitals from the Department of Public Welfare to the Department of Education).

106. Interview, supra note 104.

107. Interview of Peter Kuriloff with Gary Makuch of the Dep't of Public Welfare, in Erie, Pa., July 10, 1973. 
primarily safety and health criteria. The facilities are eligible to receive subsidies from the Department of Public Welfare but not the Department of Education. Private licensed schools operate under the aegis of the Department of Education, which requires that they meet only the most minimal educational standards.

These scliools are eligible for state aid when they provide particular children with services they cannot get through their local school system or intermediate unit, and they are approved by the Department of Education. ${ }^{108}$ Under an agreement between the Departments of Education and Welfare, P.A.R.C. implementation in both types of institutions was to be supervised by the Department of Education, with the Department of Welfare continuing to make its financial contributions toward the maintenance of children in private licensed facilities. ${ }^{100}$ The difficulties with this arrangement became clear at Allegheny Valley Sclool, a Pittsburgl-area institution which is both a state licensed facility and a private licensed school catering to severely and profoundly retarded children. Because of the sclool's apparent failure to carry out COMPILE, the Masters ordered the Pittsburgh school systein to evaluate both the scliool and its children. ${ }^{110}$ At the July 10, 1973 Masters Hearing, Dr. Ruth Scott, the Director of Programs for Exceptional Children in the Pittsburgh school district, reported that her evaluation teain had found the school "totally unacceptable" under state public education standards for special education classes. The teain also found that the scliool was misleading its chents by falsely representing many of its staff members to be various kinds of professionals. According to Dr. Scott, the administration of Allegheny Valley School, when confronted with these findings, did not agree to change its practices. Instead, it persuaded parents to fight for the school by demanding individual due process hearings for each child on the ground that the school district cannot provide for the child's medical needs. The school's physician is willing to back these claims, and the parents have threatened to sue should their children be required to return to the public school. ${ }^{111}$

\section{Deputy Attorney General Lawrence Selkowitz, who handles}

108. Interview, supra note 105; Presentation of Dr. Ruth Scott, Masters Hearing, July 10, 1973.

109. State Dep't of Educ., School Administrators Memo 535 (Aug. 9, 1972). Despite this agreement, the status of children in the state schools and hospitals remained so ambiguous that the Masters found it necessary to order both departments to make sure the children were evaluated and given appropriate instruction. Second Report, supra note 76 , at $2-3$.

110. Presentation of Jack Hagele, Masters Hearing, July 10, 1973.

111. Dr. Ruth Scott, Report on the Allegheny Valley School, July 10, 1973 (on file at $\mathrm{REO}$ in Harrisburg, $\mathrm{Pa}$.). 
P.A.R.C. matters, is pessimistic about adequately regulating either private licensed facilities or private licensed schools without changing the licensing standards. ${ }^{112}$ This is precisely what PARC wanted when it asked through its lawyer, Jack Hagele, that the standards resulting from the consent decree be incorporated into both agencies' licensing policy. ${ }^{113}$ Since other private schools, private licensed facilities, and private schools for the retarded exist to serve a variety of needs not being met by the state, a move in this direction could engender strong political resistance.

PARC officials and state administrators suspect that some rural districts have not provided any educational placements for handicapped children. Their attention lias been so focused on monitoring the quantitative aspects of COMPILE and COMPET, however, that only the inost flagrant violations have been brought to the attention of the Masters. For example, when COMPILE was first published, an ambiguity in its wording enabled several administrators from districts with very limited resources to interpret it as permitting schools to exclude profoundly retarded, multiply-handicapped youngsters, an interpretation in direct violation of both the letter and spirit of the consent agreement. While this kind of problem is easily clarified, ${ }^{114}$ only local consumer groups such as PARC can guarantee that such episodes do not recur. A more difficult problem arises when local school boards directly resist implementation in the name of politically popular economy drives. Unless careful monitoring takes place, districts without strong consumer groups are likely to neglect or evade the agreement when it suits thein.

Even when state agencies, PARC officials, and local special educators have worked together, they have encountered resistance from other educators. The problems created by the manner in which "normal" people perceive retarded children illustrate the difficulties of trying to alter the inarginal status of these children through judicial reform. For example, at a spring 1973 Masters Hearing, the parent of a retarded child coinplained that the local educators in charge of vocational/technical training reject retarded children because "they aren't ready." When Master Goldstein suggested that the local PARC chapter or local task force ${ }^{115}$ fight for a modified program to fit the

112. Presentation of Larry Selkowitz, Masters Hearing, July 10, 1973.

113. Presentation of Jack Hagele, Masters Hearing, July 10, 1973.

114. The Masters issued a clarification in their First Report, supra note 73, at 3-4.

115. Local task forces were established by COMPILE and were believed by PARC officials to hold the key to monitoring implenentation at the local level. See text accompanying notes 131-34 infra. 
children, the parent replied: "They tell you to go screw yourself."110 This attitude is held by many vocational educators. The Bureau of Vocational Education lias stated that no child with an I.Q. less than 105 would be accepted in vocational/technical schools. Many vocational sclools have not even applied for federal funding available to provide handicapped children with vocational training. ${ }^{117}$ A few programs have been developed to deal with the vocational/technical problem. Intermediate Unit $19^{118}$ has begun a pre-vocational/technical workstudy program for 20 twelve to fifteen-year-olds, in order to get them ready for (and make them acceptable to) the regular vocational program. The project may be laudable, but the fact that it is housed in a previously-closed school suggests both its marginal status and the tenacity of conventional attitudes. ${ }^{119}$

The implennentation picture is not wholly bleak. In innovative districts, new educational offerings have appeared, and there is evidence of increased interdistrict cooperation. In one Philadelphia-area district where prior to P.A.R.C. there were only classes for educable and trainable retardates, there are now two resource rooms to provide special support for otherwise mainstreamed educable elementary children, a work-study prograin for senior high school educables, itinerant teachers for the hoinebound, and a program for multiply handicapped children at a neighboring private institution. There has been a similar burgeoning of programs $i m$ two of the other four districts studied. Reports from other areas of the state suggest that these developinents may not be uncommon. Even in less innovative districts, talented and strong-willed special educators have occasionally been able to use P.A.R.C. as a lever to force the introduction of new education opportunities. In one such systein, a fifteen-year-old who had been misclassified by the school spent his entire school career in classes for the retarded. The psychologist, the student and his parent all felt that he would be hopelessly behind if he were placed directly into the tenth grade, but the district was reluctant to invent another alternative. The .psychologist worked with the boy and his parents and developed a sensible program involving a day divided between regular classwork and vocational preparation. With the psychologist's active support, the parents then used a due process hearing to persuade the district to provide such a program for their son. The P.A.R.C. agreenent also seems

116. Masters Hearing, June 12, 1973.

117. Presentation of Joseph Lantzer, Masters Hearing, June 12, 1973.

118. Pennsylvania's 569 school districts are grouped into 29 intermediate units which disburse state revenue and provide resources and services that single districts by themselves often could not afford. Their chief executive officers are called Intermediate Unit Directors.

119. Presentation of I.U. 19 representative, Masters Hearing, June 12, 1973. 
to have fostered a movement toward greater regional cooperation to solve problems relating to transportation, supervision of special education classes, and coordination of services among districts. ${ }^{120}$

\section{Monitoring Mechanisms}

Most of Pennsylvania's school districts, while in compliance with the letter of the consent agreement, lave not fully reckoned with the organizational implications of implementing a decree which requires the public education of a wholly new class of students. In the absence of some prodding by PARC, the court-appointed Master, or the State Department of Education that reckoning and reexamination is unlikely to take place. Anticipating this, the court and PARC officials, in cooperation with the state agencies, developed four monitoring mechanisms: the Masters, the Right to Education Office, the local task forces, and the due process hearings.

\section{a. The Masters}

The court appointed two Masters to oversee implementation of the decree. Their responsibilities were broad: they were charged with approving state proposals for the identification, evaluation, and placement of children who had been excluded from scliool; they heard complaints concerning nonimplementation; and they could order people to testify at hearings. They could press for preliminary judicial directives and for contempt action against officials who do not comply with the decree. ${ }^{121}$

During their first year the Masters operated as "guideline setters and dispute adjudicators," sometimes assuming the role of niediators, sometimes acting more forcefully as arbitrators. ${ }^{122}$ When the court extended the term of the Masters in October 1972 to October 1973, it required them to submit monthly reports and to attach any proposed orders which they deemed necessary to remedy noncompliance. ${ }^{123}$ This seeemed to indicate the court's willingness to be more explicit in its support of the Masters. However, for several reasons, the Masters' authority has not been fully effective. First, the court has not responded to Masters' requests. After receiving their new mandate, the Masters filed two monthly reports. In these, they suggested that the court issue four orders pertaining to the failure of the Department of Public Welfare to carry out COMPILE and COMPET, the failure of Pittsburgh to carry out its door-to-door census, the slowness of the attorney general in developing appellate procedures, and the need for the Department of

120. Interview, supra note 86.

121. 343 F. Supp. at 314-15.

122. Interviews with Dennis Haggerty, supra note 104, and Dr. Herbert Goldstein, supra note 103.

123. Order (filed June 15, 1973), P.A.R.C., 343 F. Supp. 279 (E.D. Pa. 1972). 
Education to take responsibility for private licensed facilities. By July 1973, the court liad acted on none of these. ${ }^{124}$

Why the court failed to act is not clear. While it was responsive to PARC's motions seeking remedies for noncompliance in Philadelphia, ${ }^{125}$ actions on motions from PARC are the only ones the court has taken since the issuance of the final decree in May 1972. The court may liave simply cliosen not to take an activist stance, leaving the issue with the parties. On the other liand, the Masters may liave given up too soon. Since March 1973, they have filed none of the required monthly reports. Whatever the reasons, the court's failure to back the Masters has limited their effectiveness.

Another limitation on the Masters' effectiveness may have been that both liad full-time jobs; their court assignment under the P.A.R.C. agreement was an added responsibility. Dr. Goldstein is an imternationally known expert on curriculum designed for retarded children whose work carries him around the country and often overseas. Because of these extensive commitments, lie was forced to miss several of the Masters' learings. Besides his law practice, Mr. Haggerty's interest and experience in the field of legal aspects of mental retardation have involved him in a lost of outside activities including work for the President's Committee on Mental Retardation. As a result, the time he could devote to his role as Master also has been quite limited. Compounding this problem, the limited duration of the Masters' tenure allowed stubborn school districts simply to postpone any action until after the Masters departed. A final limiting factor was the state's failure to provide the Masters with strong financial support. As a result, they were obliged to depend on the Right to Education Office to fulfill their staff requirements; the State Special Education Bureau was of limited help.

The Masters relied heavily on PARC, whicl placed many of the discussion items on the Masters' agenda, and used the sessions to question state and local officials about educational practices. The sessions thus provided PARC with a lever to apply public pressure and set in motion administrative action. The Masters Hearings were devoted almost entirely to procedural and quantitative matters, with very few agenda items touching on the quality of new programs. In part, this focus represented a strategy, carefully thought out by PARC, designed to make sure that the Masters created sufficient structure to ensure continued implementation of the reforms once their term expires. In part, too, it might simply imdicate the difficulty in dealing with a con-

124. Presentation of Dr. Ruth Scott, presented orally, Masters Hearing, July 10, 1973 (report to the Masters on the status of the Pittsburgh census).

125. Order (filed Apr., 1973), P.A.R.C., 343 F. Supp. 279 (E.D. Pa. 1972). 
cept as vague as "appropriate education." The stress on procedures may also reflect what Master Herbert Goldstein believes to be the difficulties of sustaining consumer pressure at the local level once the primary motivating factor-in this case, the presence of retarded children in the home or in non-responsive and sometimes highly expensive institutions-is removed. ${ }^{126}$

Even with all the limitations of their role, it would be a mistake to discount the importance of the Masters. They provided a readily accessible forum in which PARC was able to raise questions and bring complaints. More important perhaps, it was a forum clothed in the dignity of a federal court having the power to require the appearance of representatives of key state agencies. This aura of power has spurred most of the districts in the state into at least the semblance of compliance. School administrators were awed by the Masters, sometimes working weeks to prepare a written report in anticipation of being called to testify. ${ }^{12 \pi}$ It is difficult to assess the impact of this symbohic extension of the court, but it is clear that a remarkable degree of interagency cooperation was achieved because of it.

The Masters have made substantive contributions beyond those resulting from their perceived power. Where the court did not adopt their suggested orders, the Masters nevertheless achieved their ends by prodding and persuading the various non-complying parties. They also kept soine matters out of court by successfully mediating disputes. ${ }^{128}$ By bringing together interested parties from all over the state for hearings and special sessions, the Masters educated people to the meaning of the decree and to the ideas-such as the educability of all childrenunderlying it. Finally, they not only supervised the implementation of COMPILE and COMPET, but saw to it that COMPET will be rewritten on the basis of the 1972-73 experience. Thus, while the Masters were constrained by the way their role was structured, without them P.A.R.C. implementation would have been even more chaotic and disorganized than it has been.

\section{b. The Right to Education Office}

When Governor Shapp established the Right to Education Office shortly after the consent agreement was issued, PARC strategists saw it, along witl the due process hearings and the local task forces, as one

126. Interview, supra note 103.

127. On one occasion, a group of intermediate unit directors, experienced at facing public situations, were overheard in the men's room before a Masters Hearing discussing who might have to "go first." This fear is all the more ironic given the relaxed and relatively informal way in which Dennis Haggerty ran the hearings.

128. See text accoinpanying note 101 supra. 
of three keys to successful implementation. The Office was given the responsibility of overseeing implementation of the consent agreement. It was to develop a plan to identify, evaluate, and educate retarded children; nonitor implementation; gather data and oversee the due process hearings, including accepting requests for such hearings, assigning officers, and maintaining records. Fimally, it was to serve as a staff for the Masters.

As the agent of the State Departinent of Education, the Right to Education Office was in the position to develop standards, establish program guidelines in terms of content, staffing patterns, in-service training and the like, and evaluate outcomes through careful monitoring. To do this, it gathered a staff of twelve: a director and business manager (both on loan from the Department of Education), an inservice consultant (on loan fron1 the Department of Public Welfare), four area coordinators, and five secretaries (funded by a one-year, renewable federal grant). While the size of the Right to Education Office, exceeding that of the Bureau of Special Education, suggests the strong commitment of the state to implement the P.A.R.C. agreement, ${ }^{128}$ the Office's temporary nature and precarious funding have proven to be serious roadblocks to full effectiveness. Because officials attuned to the politics of state bureaucracy perceive Joseph Lantzer, the Rigltt to Education Office's Director, as a once and future employee of the Bureau of Special Education, his authority has been undermined from the outset. Perhaps more important, imstead of being able to operate as a free and independent regulatory agency, the Right to Education Office lias had to function essentially as the arm of a typically politicized state bureau. As a result, the Office has moved cautiously on sucl sensitive questions of compliance as the resistance of the Philadelphia School District.

Despite these organizational problems, the Right to Education Office staff has received high marks from both PARC officials and the Masters for its dedication to the principles of the consent agreement and for its efforts to ensure implementation. ${ }^{130}$ Furthermore, all agree that the Right to Education Office could be highly effective if it were

129. In fact, this was cited as evidence of the commitment of state agencies by the Masters in their First Report, supra note 73. That the Right to Education Office was the only state bureau, other than the einergency office for flood relief, kept open during the terrible 1972 spring flooding in Pennsylvania provides further indication of the aniount of state backing the consent decree received.

130. In separate interviews with Peter Kuriloff, this kind of appreciation was expressed by Marliene Sinoker, Assistant Director for Administration and Governmental Affairs for PARC, in Harrisburg, June 12, 1973, and Peter Poloni, Executive Director of PARC, in Harrisburg, Jan. 15, 1973, as well as by Masters Haggerty in Philadelphia, May 8, 1973, and Goldstein, in Philadelphia, June 11, 1973. 
made a permanent and independent agency. PARC views this as one of its major objectives as it prepares for a future without the Masters.

\section{c. The Local Task Forces}

COMPILE required the establishment of local task forces to help school districts carry out evaluation and planning. They were to be organized by the Intermediate Unit Executive Directors, who were to select task force members from representatives of consumer groups and the administrators of the local school districts, county mental health and mental retardation centers, and private agencies. ${ }^{131}$ It was PARC's hope that the task forces would provide a means for consumers to be heard where it counted most - at the individual program level. PARC offficials now consider this aspiration even more important since the due process hearings liave not proven as effective in promoting appropriate educational placement as originally hoped. ${ }^{132}$

The operation of the local task forces has been hampered by serious flaws in their original conception. While specifying their responsibility, COMPILE indicated neither the source of their power nor the scope of their authority. Their membership is selected by, headed by, and reports to the Intermediate Unit Director. Since he is not required to follow their recommendations, their power is inerely advisory. Furthermore, Intermediate Unit Directors have no authority over District Administrators; for that reason, even if the local task forces had real authority, it is unlikely that it would extend beyond intermediate unit programs to those established by individual districts.

With the October expiration of the Masters' term, many gaps still remain between the concept and implementation of the consent agreement. Unless the local task forces are empowered to inonitor implementation, many apparent gains will be lost. Recognizing this, PARC appealed to the Masters to clarify the local task forces' responsibility and authority. At the January 1973 Masters' Hearing the Director of the Right to Education Office was asked to respond. He reported that the idea of giving the local task forces real authority was meeting with bureaucratic resistance. He described how he had recently been asked by the State Task Force ${ }^{133}$ to draft a policy statement on the subject.

131. CoMPIIE, supra note 70 , at 11 .

132. E. Schmidt, Resource Review Team (Draft), June 12, 1973 (on file with Peter Kuriloff).

133. The State Task Force consists of the Director of the Bureau of Special Education, the Commissioner of Mental Retardation, a representative of the Governor's Office, and representatives of consumer/citizens groups. It has the responsibility of communicating with, and soliciting the cooperation of, all governmental agencies and state level consumer groups about the implementation of COMPILE and COMPET. CoMPILE, supra note 70 , at 4. 
Though he had proposed giving substantive power to local task forces, the draft finally approved by the State Task Force was considerably watered down. The Masters were not able to obtain agreement on a inore authoritative role for the local task forces before their final hearing, but PARC continues to pursue the matter, threatening judicial action to force increasing the task forces' power. Unless that happens, the parents of retarded children may find theinselves without any vehicle for momitoring the quality of local educational programs.

\section{d. Due Process Hearings}

Those who framed the P.A.R.C. agreement recognized both the importance and the difficulty of securing structural change. They hoped that the guarantee of a due process hearing would promote inore carefully considered educational placements for special children and, ultimately, general reexamination of special programs. Thomas K. Gilhool expressed these aspirations im a memorandum to PARC:

For the first time in American education, a mechanism is created to assure that the educational program fits the child. The mere fact of a hearing opportunity . . . will of course keep all the field professionals on their toes. There is a new instrument of accountability. . . . The right to a hearing creates an extraordinary forum for parents and their associations to express theunselves, raise issues, enforce rights, get things done, and to organize. . . . The hearing is a forum which should transform the parents' movement. . . . And it should transform education. ${ }^{134}$

The formal hearing requirements assure parents of a retarded child the right to a hearing upon initial school placement, after any program change, and after every two years of special class assignment. Prior to the hearing, parents inay examine the school records on which the recommendation is based. They may retain counsel or professional assistance. During the hearing, they have the right to have the hearing either closed or open to the public. ${ }^{135}$ They are entitled to summon and question all the school personnel involved in the decision.

PARC and state education officials noved quickly to set up the hearing mechanism. Sixty-one hearing officers, endorsed both by PARC and the state, were appointed. In May 1972, a first group was given a quick training course by Toin Gilhool and Ed Weintraub, a Pennsylvania Deputy Attorney General, which familiarized them both with the decree and with the hearing procedures. But following an agreeinent between counsel, traming was suspended after this first session. As a result, only thirteen officers had been trained and were working

134. Right to Education, supra note 57, at 58.

135. 343 F. Supp. at 303-06. 
by August. This caused a serious backlog of cases, and placed a heavy burden on the trained hearing officers, who are all employed elsewhere full time. ${ }^{136}$ The Right to Education Office took steps to remedy this problem, however, and by the fall there were 34 working officers, drawn from positions in public special education and from colleges and universities. As of April 1973, 255 hearings had been applied for across the state; 47 had been held, and decisions reached in 43 . Sixty-nine of the requested hearings had been cancelled. In the 25 hearings open to the public, 13 decisions upheld the school's recommendation, while the balance were decided in favor of the parents-a result which does not necessarily mean the children received a more appropriate education. ${ }^{137}$ Parents represented by counsel were significantly more likely to win a favorable ruling. ${ }^{138}$

Although the P.A.R.C. decree sets forth rudimentary substantive guidelines for the conduct of the hearings-for example, the presuniption that regular class placement is preferable to assignment to a special class-the individual hearing officer, who is usually a special educator, decides how the hearing is to function. Some of the hearing officers are still confused about their role. PARC officials assert that some hearing officers have turned away cases on the grounds that transportation issues are beyond the scope of the due process hearings, others on the grounds that appropriate programming is unreviewable. ${ }^{130}$ Where proper hearings have been held, some PARC spokesmen have noted that not all avenues of search have been undertaken to assist in proper placement or appropriate programming, even though it is the officers' duty to order such a search if they find it necessary. ${ }^{140}$ Finally, PARC officials claim that the presence of lawyers has created problems at some hearimgs since, unlike educators, lawyers tend to focus more on the procedural than on the substantive questions. ${ }^{141}$

136. First Report, supra note 73, at 4-5.

137. Many lawryers and educators have argued that the less adversarial the hearing, the more chance there is of arriving at a good plan for the child. This argument is developed in Part III of this Article.

138. This was determined by using the $\mathrm{X}^{2}$ technique on the following table:

Lawyer present

Lawyer not present

\begin{tabular}{c|c} 
Parent "Wins" & Parent "Loses" \\
\hline 9 & 3 \\
4 & 9 \\
\hline & $\mathrm{X}^{2}=4.89$ \\
$\mathrm{p}>.05$
\end{tabular}

Since the cell values are so sinall, this finding should be considered as merely suggestive.

139. Interview of Peter Kuriloff with Jack Hagele, in Philadelphia, July 10, 1973.

140. E. Schmidt, supra note 132, at 2.

141. Id. This complaint may stem from a misunderstanding of lawyers' methods during the hearings, rather than from a failure on the part of the lawyers to grasp the substantive issues. 
No provision has been made to encourage hearing officers to read each other's decisions. No one-neither other hearing officers, nor the lawyers, nor PARC officials-has had access to the hearing transcripts or the written decisions in closed hearings. A preliminary canvass of the decisions suggests that an argument that may prevail before one officer will be rejected by another; and, since there have been no decided appeals (as of this date) there exists no system of precedent to guide the decision-maker. The best that the parties to a dispute can hope for under such circumstances is what David Matza has termed "individual justice."142 The implementation of individual justice poses problems both for the school system and for the parents. The parent challenging a particular placement has no way of knowing what sort of proof will be appropriate, what evidence is to be credited, or what procedural burdens (if any) he must surmount. School officials are similarly confused.

There is, of course, a standard-"appropriate education"-which in theory governs the inquiry. ${ }^{143}$ But that standard is so broad and elastic that the hearing officer cannot apply it in routine fashion. Instead, he must choose among versions of that standard, adopting criteria that necessarily vary from hearing to hearing, and from hearing officer to hearing officer. The process by which decisions are reached seems similar in many respects to that of the juvenile justice system, although the ostensible goals of the two types of hearings differ. In both situations, "hardly anyone and least of all the recipients of judgment who have some special interests in these matters, is at all sure what combinations of the widely inclusive relevant criteria yield what sort of specific dispositions." 144

The availability of hearings has been a useful pohitical tool, both for parents and school officials. Officials have threatened parents with a hearing as a means of obtaining acceptance of the recommended placement; for soine parents, concern about publicity, discomfiture with adversariness, and the quite real possibility of losing coine perilously close to coercion. Many of the same factors operate to the advantage of more activist or recalcitrant parents; ${ }^{145}$ the cost of the hearing-in time, although not in dollars-may lead districts to acquiesce

142. D. Matza, Delinguency and DRIfT 111 (1964).

143. Hearing officers in fact make choices, rather than resolving differences, much as an arbitrator might. But the conduct of the hearings generally has been informal, a style associated with mediation. See Fuller, Adjudication and the Rule of Law, 1960 Proceedings of the AM. SOC'Y OF INT'L L. 1.

144. D. MATZA, supra note 142 , at 115.

145. This is the case in the Allegheny Valley School situation, in which parents threaten to use hearings as weapons to keep the school district from removing their children from Allegheny Valley. R. Scott, supra note 111. 
in the parents' wishes about placement. ${ }^{146}$

Hearings can also have serious unexpected consequences. In one district in the north-eastern part of the state, parties to the hearings became so antagonistic that the teachers present became extremely upset; subsequently, teachers throughout the district referred no more children for evaluation to the intermediate unit. This episode suggests that teachers may not understand the purposes of the due process hearings. More importantly, it means that hearings can be conducted in a manner that not only defeats the spirit of the decree, but also keeps children needing other kinds of help from receiving it. It is another example of the complex dynamics which must be taken into account in order successfully to implement the reform contemplated in P.A.R.C.

In two respects the formal hearing procedures have been modified since the P.A.R.C. decree. First, in order to resolve essentially technical disputes-for example, what transportation is to be provided to get a particular child to his special program-the Department of Education has introduced an informal prehearing session. Second, both PARC and the state have adopted a mechanism for appealing from the hearing decision. Such disputes are heard first by the Secretary of Education, whose rulings may then be appealed to the commonwealth court. ${ }^{147}$

\section{Recapitulation}

More than a year after the court approved the P.A.R.C. consent decree, the evidence tells an uneven tale. Pennsylvania has been able to identify some 7,400 previously excluded children, a feat which can be credited both to strong official support and to the persistent efforts of an active statewide parents group. But with respect to the more basic educational and organizational questions-the evaluation and "appropriate" placement of exceptional children-the results are far less clear. The organization and nature of speech educational services, although expanded, remains generally the same. As Master Herbert Goldstein notes:

Unfortunately, the state has not tackled its substantive issues with the same zeal and flamboyance as the procedural questions. The results-thus far-are an array of facades (finding, testing, placing, etc.). . . . But there isn't much new educationally in Pennsylvama, as an outcome of the case. . . If the state educational

146. Pennsylvania officials estimate the dollar costs of each hearing at $\$ 500$-about half the amount spent on the schooling of a typical Pennsylvania child each year. The state, and not the school district, bears this cost. Interview of Peter Kuriloff with William Orhtman, Chief of Bureau of Special Education, in Harrisburg, Jan. 9, 1973.

147. Masters Hearing, July 10, 1973. 
people do not change their ways and begin aggressively to re-shape and originate, facades are all that Pennsylvania will have. ${ }^{148}$

\section{B. Mills v. Board of Education ${ }^{140}$}

\section{Introduction: A Beleagured School District}

Washington, D.C. has a crisis-prone school system. The overwhelming majority of the District's 140,000 students are black and poor:;150 teacher turnover is high; and superintendents have come and gone with remarkable frequency. ${ }^{151}$ The city is property-poor, as its most valuable land is held by tax-exempt public and private institutions, and it must depend for its schools' fiscal support on the Congressional committees responsible for District affairs. The schools have been repeatedly studied by educational professionals, all of whom have urged sweeping changes. ${ }^{152}$

Demands for change in Washington's schools have been the subject of judicial action as well. The sweeping decision in Hobson $v$. Hansen ${ }^{153}$ sharply criticized a host of school practices: the segregation of both students and faculty, the disparity in resources available to predominantly white and black schools, and the discriminatory effects of the District's rigid tracking system which locked most blacks into deadend school careers. ${ }^{154}$ While the district court's directive that the existing tracking system "must simply be abolished"165 was watered down by the Court of Appeals, ${ }^{156}$ the school system apparently terminated a number of special education classes because of its erroneous understanding of Hobson. ${ }^{157}$

Washington's judicial headaches did not cease with the first $\mathrm{Hob}$ son decision. In 1970 the case was reopened, ${ }^{158}$ and the court again

148. Written comment to an earlier draft of this section, July, 1973 (on file with Peter Kuriloff).

149. 348 F. Supp. 866 (D.D.C. 1972). Fieldwork for this section was conducted between Dec. 1972 and Oct. 1973.

150. Address by Hugh J. Scott, Superintendent of Washington, D.C. Schools to the Washington, D.C., City Council on the fiscal year 1974 budget, Jan. 5, 1973.

151. Washington has had four school superintendents since 1967.

152. See, e.g., H. Passow, Toward Creating a Model Urban School System: A STUDY OF THE WASHINGTON, D.C. PUBLIC SCHOOLs (1967).

153. 269 F. Supp. 401 (D.D.C. 1967), appeal dismissed, 393 U.S. 801 (1968), aff'd en banc sub nom. Smuck v. Hobson, 408 F.2d 175 (D.C. Cir. 1969).

154. Id. at $406-07$.

155. Id. at 515 .

156. The Court of Appeals' decision limited the applicability of the district court order to the existing tracking system, while permitting "full scope for . . . ability grouping." 408 F.2d 175, 189 (D.C. Cir. 1969).

157. See Herr, Retarded Children and the Law: Enforcing the Constitutional Rights of the Mentally Retarded 23 SYR. L. REv. 995, 1008-15 (1972) [hereinafter cited as Herr].

158. Hobson v. Hansen, 327 F. Supp. 844 (D.D.C. 1971). 
considered allegations that school spending policies favored schools in the predominantly white neighborhood west of Rock Creek Park. The court ordered the equalization of expenditures for teachers throughout the system but permitted the District to spend additional funds for "exceptional children."159 Mindful of the District's problems in implementing the first Hobson decree, the court required regular and detailed reporting of relevant data. ${ }^{160}$ But still the school system responded so slowly that in 1972 plaintiffs brought a contempt action. ${ }^{161}$ The District was not displeased with the Hobson decision-indeed, it declined to appeal the ruling; but its ungainly and generally inefficient school bureaucracy seemed simply incapable of effecting the required changes. $^{162}$ One year after the second Hobson decision the saune bureaucracy was confronted with the even greater challenge of complying with Mills v. Board of Education. ${ }^{163}$

\section{The Scope of the MiLLs Decree}

In many respects, Mills and P.A.R.C. were similar efforts. Both sought to establish the constitutional principle that children excluded from school as "ineducable" were entitled to publicly supported education; and both insisted that procedural protections be provided to children prior to placement in special programs. The plaintiffs in Mills, however, represented a broader range of excluded children, including students who had been barred from school as incorrigible discipline problems and students denied an education because of physical, mental, or emotional handicaps. The Mills plaintiffs hoped to establish the principle that all children, regardless of their disabilities or behavioral symptoms, are constitutionally entitled to publicly supported schooling.

Unlike P.A.R.C., the Mills suit can fairly be characterized as a lawyers' venture. Although the D.C. Family Welfare Rights Organization supported the litigation and appeared as a "next friend" of one of the young plaintiffs, there existed in Washington no broad-based parents' group historically committed to and able to follow through on the issue. ${ }^{164}$ Instead, three public-interest legal organizations-the National

159. Id. at 863-64.

160. Id. at 864 .

161. Hobson v. Hansen, Civil No. $82-66$ (D.D.C., filed Jan. 17, 1973) (contempt motion denied).

162. Herr [supra note 157, at 1013] accurately refers to the "Byzantine irresponsibility" of the Washington bureaucracy.

163. 348 F. Snpp. 866 (D.D.C. 1972).

164. Memorandum to David Kirp from Patricia Wald, Mental Health Law Project staff attorney, Implementing Mills: The First Six Months, Mar., 1973 (on file with David Kirp) [hereinafter cited as Memo]. 
Legal Aid and Defender Association, the Center for Law and Social Policy, and the Harvard Center for Law and Education - spent nearly two years planning the litigation. ${ }^{165}$ Their efforts paid off. ${ }^{160}$ In $\mathrm{Au}$ gust 1972, three months after P.A.R.C., Federal District Court Judge Joseph Waddy handed down an order which provided substantially all the relief plaintiffs had requested. ${ }^{107}$

The court's discussion of the constitutional merits of this very important decision was remarkably cursory. ${ }^{188}$ It found constitutional warrant for the universal right of access to publicly supported schooling in Brown v. Board of Education ${ }^{169}$ and Hobson v. Hansen, ${ }^{170}$ and concluded broadly that "[d]ue process of law requires a hearing prior to exclusion, termination or classification into a special program."171 Although the court noted that school officials had failed "to abide by the provisions of ... previous orders" and demonstrated "continuing failure to provide an education" for excluded children, ${ }^{172}$ it declined to follow P.A.R.C. and appoint a master to oversee implementation of the decree. Responsibility for developing and carrying out a plan to identify, evaluate, and provide suitable educational opportunities for previously excluded children was left entirely to the District.

\section{The Implementation Plan \\ a. The Hope}

The phight of Washington's handicapped children was hardly news to school officials. For several years, frustrated parents had sought an increase in the District's tuition-grant program that enabled handicapped children to attend nonpublic special schools at city expense. ${ }^{173}$ In Deceinber 1971, a Task Force on Special Education appointed by the Superintendent of Schools reported that:

165. Id. These organizations initially sought to intervene in the reopened Hobson case, arguing that Washington's exclusion policy flowed partly froin a misreading of the first Hobson decree. Although denying the motion to intervene, the court characterized the plight of the excluded children as a "human tragedy, unbelievable as it is in the capital of the richest country on earth." Hobson v. Hansen (D.D.C., June 17, 1971) Ruling on Motion to Intervene at 3-4, July 23, 1971, as quoted in Herr, supra note 157, at $1008 \mathrm{n} .70$.

166. Id.

167. Id.

168. Mills v. Board of Educ., 348 F. Supp. 866, $874-75$ (D.D.C., 1972).

169. 347 U.S. 483 (1954).

170. Hobson v. Hansen, 269 F. Supp. 401 (D.D.C. 1967).

171. 348 F. Supp. at 875 .

172. Id. at 877 .

173. Complaint, Exhibit D, Mills v. Board of Educ., 348 F. Supp. 866 (D.D.C. 1972) (Julius W. Hobson, The Tuition/Grant Program of the District of Columbia Public Schools, report to the District of Columbia Board of Education, November 19, 1969). 
In the city of Washington, the acknowledgement of the right of the handicapped child to public education has been honored more in the breech [sic] than by observance. The obscene nightmare of repetition from year to year continues for the parents of these children who must compete for placement and for funds or accept the exclusion of their child from the opportunity to develop his liuman potential. ${ }^{174}$

The District's activity immediately after Mills suggested that notable alterations in both policy and practice might be forthcoming. A man with respected academic credentials in the field of special education, Merle Van Dyke, was appointed Assistant Superintendent for Special Education. The impleinentation plan $^{175}$ submitted. by the School Board one month after the Mills decree appeared to be comprehensive and imaginative, if somewhat vague. It emphasized keeping all but the inost severely handicapped children in the regular schoolroom setting. ${ }^{178}$

\section{b. Identification}

Just as in Pennsylvania, no one really knew how many school-age children in Washington, D.C. were being denied an education. An internal memorandum indicated that the District was aware of 1,500 children identified as requiring specialized education who were on waiting lists for placement, ${ }^{177}$ and Mills refers to another memorandum which estimated that " 12,340 handicapped children were not to be served in the 1971-72 school year."178 It is unclear how many of the children referred to were receiving no schooling at all and how many were in school but denied special services which the school system thought they needed.

The District proposed an assortment of approaches to identify these excluded children. ${ }^{179}$ Its Department of Pupil Personnel Services was made responsible for conducting court-ordered quarterly outreach efforts that included advertising on local television and radio stations and in the newspapers. The District promised to conduct an annual census of children aged three to eighteen years if Congress could

174. Task Force on Special Education, Report of the Superintendents' Task Force on Special Education 1 (Public Schools of the District of Columbia) (Dec., 1971).

175. Public Schools of the District of Columbia, Compremensive Plan for Special Education: AN ABstract (1972) [hereinafter cited as PLAN].

176. Id. at 2.

177. Washington, D.C. Dep't of Special Educ., Nerds of Exceptional ChilDREN IN THE DISTRICT OF COLUMBIA 14, Oct. 1971 (report to the Superintendent of Schools, on file with the Department of Special Education).

178. Mills v. Board of Educ., 348 F. Supp. 866, 868-69 (D.D.C. 1972).

179. PLAN, supra note 175 , at $2,16-17$. 
appropriate the funds, ${ }^{180}$ and would require semi-annual reports of all children receiving special services from agencies or schools other than the public schools. The Department of Special Education would report quarterly on the number of children it was serving in various programs, and teachers and principals would seek out and make referrals of youngsters wlio appeared to need supplementary help.

\section{c. Evaluation and "Suitable" Placement}

The implementation plan sought to minimize segregation of handicapped children: it stressed the need to deliver special services in the regular classroom and to return children requiring services in a special education environment to the regular classroom as quickly as possible. ${ }^{181}$

Nime levels of educational programming were specified for children with special problems. Level I to III children could stay in regular classrooms with special supportive help from educational assessment teams (professionals skilled at evaluation), school-based specialists, and mobile diagnostic and crisis teams. ${ }^{182}$ These special personnel would initially undertake careful evaluations of children hastily placed in special programs at the beginning of the school year, and subsequently evaluate children in regular classes for whom some special lielp might be beneficial. ${ }^{183}$ Level IV children, those homebound or in hospitals, would be served by instructors who would visit the home school and attempt to keep the student up with his class. ${ }^{184}$ Level V children, seven-to ten-year-olds with mild to moderate problems, would be placed in "non-categorical compensatory learning centers" away from their home school on a lialf-day basis. ${ }^{185}$ Level VI children include visually impaired and trainable mentally retarded youngsters. Visually impaired children ready for a flexible environment would be placed in special classes in the regular school and eventually moved into the regular school setting with an itinerant teacher. The trainable mentally rctarded would be placed in neighborhood-based special classes providing as much integration into the regular program as possible. ${ }^{180}$ Level VII children mclude the blind, deaf, severely retarded, physically

180. Such a census had long been required by law, D.C. Code ANN. $\S 31-208$ (1973), but had never been conducted.

181. PLAN, supra note 175, at 1-2.

182. The mobile crisis teams have been dropped as unworkable. Public Schools of the District of Columbia, Goal VIII: Special Education 32 (June 1973) (copy on file with David L. Kirp) [hereinafter cited as Goal VII].

183. Plan, supra note 175, at 3-5.

184. Id. at 5 .

185. Id. at 5-6.

186. Id. at 6 . 
handicapped, and emotionally or behaviorally disturbed, who would be placed temporarily or permanently in special schools. ${ }^{187}$ Level VIII youngsters are those placed in psycho-theraputic day care programs at mental health centers. Educational programs taught by special-education instructors would supplement the care they had previously received. ${ }^{188}$ Level IX children, those for whom no appropriate placement can be found in the public schools (e.g., the multiply handicapped), would receive tuition grants to private schools. ${ }^{189}$

The Plan further provided for retraining regular teachers; and principals and central administrators were to participate in a staff development program to learn about their responsibilites under Mills. ${ }^{100}$ The Board of Education committed itself to making budget requests for fiscal year 1974 and beyond that would "accurately reflect the needs of exceptional children." ${ }^{\text {191 }}$ But between the Plan's promise and its fulfillment, several things went awry.

\section{The Implementation Reality \\ a. The Lack of Data}

No one in Washington knows fully what impact Mills has had. The court decree made no provision for data-keeping or for reporting to the court, the welfare rights group, plaintiffs' attorneys, or the public. While the district's own plan contemplates some reporting, ${ }^{192}$ the scope and details of that responsibility remam unclear. The absence of official pressure for periodic reporting means that there is no guarantee of information-gathering except at budget-making time. For instance, at any given time it is almost impossible to find out how many disturbed children are totally out of school; how many are in school but not receiving the services they need; and how nany are undergoing assessment. $^{103}$

\section{b. The Identification Problem}

Washington's outreach efforts were considerably less sophisticated than Pennsylvania's. In August and November 1972, the District

187. Id. at 6-8.

188. Id. at 8.

189. Id.

190. Id. at 20.

191. Memo, supra note 164 .

192. PLAN, supra note 175 , at $16-17$.

193. Written comments of Patricia Wald to the authors on an earlier draft of this section, Oct. 30, 1973 [hereinafter cited as Comments.] See Washington StarNews, Oct. 14, 1973, at C-1, col. 2 (Mr. Van Dyke, assistant superintendent for special education, citing figures but uncertain what they represent). 
advertised over radio and television and in the three local newspapers. The first set of newspaper advertisements appeared in the classified ad section and were addressed to "handicapped children." Later, ads more fetchingly captioned "Children Wanted" appeared in the inovie section. ${ }^{194}$ Responses to these advertisements were considerably fewer than had been anticipated: only 185 exceptional children and 453 suspended students were located. No annual school-age census has as yet been undertaken for the money needed for the task cannot be found. Despite these mauspicious beginnings, the Assistant Superintendent for Special Education reported that as of October 1973, 11,000 children were receiving some special-education services-a nearly three-fold imcrease over the previous year. ${ }^{195}$ Where these new students came from and the nature of the educational services they received cannot be deduced from the District's data. ${ }^{196}$

There may well remain a number of unserved children. Washington provides only one class (with a capacity of 20 students) for severely and profoundly retarded children; less than a dozen others receive tuition assistance enabling them to attend the few private schools in the area which accept such children. School officials have estimated that at least 100 seriously handicapped youngsters, inany nonambulatory, exist unknown to school officials. There are also persistent reports that some day care programs attended by exceptional children still offer only custodial or recreational services. ${ }^{197}$ The educational opportunities available to the children institutionalized in the local school for the retarded and St. Elizabeth's hospital for the inentally ill remain a mystery: the Board of Education and Department of Human Resources have yet to work out a joint program for them. ${ }^{198}$ At least 30 children eligible for tuition vouchers have been kept out of school by the District; $; 199$ an additional 150 such exclusions are presently anticipated by District administrators. ${ }^{200}$ While the District claims that waiting hists are a thing of the past, names of children still out of school continue to turn up, encouraging the conclusion that while there are no lists, there are still people waiting.

194. Memo, supra note 164.

195. Washington Star-News, Oct. 11, 1973, at C-1, col. 3.

196. Ms. M. Louise Malone, Assistant Executive Director of the District of Columbia Citizens for Better Public Education, notes that 11,000 students is a deceptive figure simce, unlike earlier calculations, it includes students who receive any help, however sporadic, from special educators. Telephone interview of David L. Kirp with M. Louise Malone, Nov. 16, 1973.

197. Memo, supra note 164.

198. See text at notes $304-05$ infra.

199. Washington Star-News, October 11, 1973, at C-1, col. 3.

200. Memorandum from Merle G. Van Dyke, Assistant Superintendent to Barbara Sizemore, Superintendent, October 16, 1973 (on file with David L. Kirp). 


\section{c. The Information Problem: Teachers and Principals}

People were understandably confused about the scope of the Mills decision. Many, including principals, focused only on the student-discipline aspects of the case. ${ }^{201}$ They thought Mills barred all suspensions and would cripple efforts to maintain school discipline, ${ }^{202}$ while in fact it permits suspensions prior to a hearing if the principal decides the pupil is a physical threat to himself or others, and for ten days after a hearing. ${ }^{203}$ In November 1972, several high school students were arrested for possession and use of marijuana on the grounds of one of the District's high schools. In a widely circulated statement, the principal deplored the fact that because of Mills he could not render the custoinary suspensions, and irate parents threatened to take the matter to the Board of Education. ${ }^{204}$ Concern about the implications of Mills on control of student discipline persists. One principal commented: "If the schools kneel to the Waddy decree, we'll have all kinds of thugs in the high school."205 A teachers' union leader shared that view: "We cannot be actively held responsible for the education of any child in the district while forced [by Mills] to keep unruly children in school." ${ }^{200}$

To implement a decree such as Mills, which radically alters the functioning of the school, the understanding and cooperation of those who must carry out its mandates-particularly principals-is crucial. If principals view impleinentation as a low-priority matter, they are unlikely to attend seriously to it. And even if principals do recognize that school exclusion is educationally indefensible-and illegalthey are likely to treat children once excluded as no longer their concern but solely that of the special-education department. School organization has historically encouraged such divisions of responsibility. The District's training program, designed to alter this pattern of regular system behavior, has not been a notable success. Despite a district claim that "an administrator froin virtually every school" ed a special course following Mills, many of the principals and teachers in the system remain unfamiliar with the Mills decree. Training sessions for school personnel have been held periodically since Sep-

201. See Washington Post, March 10, 1973, at E-1, col. 4.

202. See Education USA, May 14, 1973, at 205.

203. 348 F. Supp. at 883.

204. Hearings on the Aftermath of Mills Before the Subcomm, on Education of the House Committee on the District of Columbia, 93d Cong., 1st Sess., (May 29, 1973) (not yet established) [hereinafter cited as Hearings]. Superintendant Scott furthes testified that the number of suspensions has in fact decreased since Mills. Id.

205. Washington Post, May 2, 1973, at C-1, col 7.

206. Id.

207. Goal VIII, supra note 182 , at 1 . 
tember 1972. Most sessions, however, tend to be windy lectures mixing information and misinformation. Discussion is at best sporadic, and simce attendance at the entire session is not obligatory, much of the audience drifts away. ${ }^{208}$

Those who work in the scliools have not denied that pupils who have been barred from school as ineducable desperately need help. Numbers of teachers have expressed regret that it took a lawsuit to commit the system to educate every child. But such sentiment has httle practical utility unless the school district offers information and training to reckon with the needs of these children, and the resources with which to do the job. Thus far, neither has been forthcoming.

\section{d. Resources: The Problem of Competing Priorities}

The provision of "suitable" education-the Mills requirementis a complicated and expensive matter. Yet despite the fact that the district, responding both to Congressional mandate and federal court order, has substantially enlarged its special education budget, considerable problems remain. ${ }^{209}$

Between 1971-72 and 1973-74, moneys available for special education increased froin $\$ 7.277$ million to $\$ 10.197$ million; ${ }^{210}$ much of that jump was due to a special 1972 Congressional appropriation of $\$ 2.1$ million. ${ }^{211}$ These additional funds were used almost entirely to hire new school-based "crisis resource" teachers: special education staff increased from 495 in 1971-72 to 641 the next year. ${ }^{212}$ But these increased allotments have not kept pace with enrollment, which has climbed steadily with the implementation of the 1972 plan. School officials have repeatedly and publicly admitted that there were imsufficient resources to accommodate previously excluded children in appropriate programs. ${ }^{213}$ Although resources may well be madequate, the District's use of funds is, at best, question-provoking. Despite repeated stateinents by school board members that the education voucher prograin would have to be drainatically expanded to meet the immediate needs of previously excluded children, ${ }^{214}$ the voucher budget has

208. Memo, supra note 164 (Ms. Wald attended some of the training sessions); Letter to David L. Kirp from Frank Wiggin, Nat'l Legal Aid and Defender Ass'n, Feb. 15, 1973 (Mr. Wiggin also personally investigated the training sessions.).

209. Interview, supra note 196.

210. Public Schools, District of Columbia, Fiscal Year 1974 Budget at GA-500-1 (Jan., 1973) [hereinafter cited as FY 1974 Budget]; Fiscal Year 1975 Budget Summary, Schedule 4 (Oct. 26, 1973) (both on file with David L. Kirp).

211. Interview, supra note 196.

212. FY 1974 Budget, supra note 210 , at GA-500-3.

213. Washington Star-News, Oct. 14, 1973, at C-1, col. 2.

214. Mason, Report on Sepecial Education Tuition Grant Funding, Oct. 19, 1973 (report to the Board of Education) (on file with David L. Kirp). 
remained stable and the numbers of students receiving vouchers has actually been cut. Only a threatened lawsuit precipitated hasty efforts to transfer $\$ 670,000$ from various surplus accounts to augment the voucher program. ${ }^{215}$ While assessment and placement of previously excluded children, required by Mills, should have been a first priority of the district, the effort still has not been completed. Thirtynine psychologists in the Pupil Personnel Office serve the entire district, although 15-20 more are needed to satisfy the demand for their services. Only 10 psychologists and six social workers serve one area which encompasses 51 separate schools. ${ }^{216}$

If the demand for services truly outstripped available resources, one would expect some needs to go unmet. But bureaucratic inefficiency has compounded one problem. In June 1972, \$1.7 millionnearly $20 \%$ of the special education funds-remained unspent. One year later, the District was unable to spend $\$ 757,000$ of its budget. ${ }^{217}$

Nor has the District proposed further increases in the special education budget. In January 1973, the Associate Superintendent for Special Education sought $\$ 2.622$ million in new funds to improve placement procedures, develop prograins for profoundly retarded, preschool, and learning-disabled children, and to augment the meagre staff development prograin. ${ }^{218}$ He noted: "The programs are not listed on a priority basis as all are of critical import."219 The request was ignored, and the 1973-74 budget provided for an increase of just seven percentfrom $\$ 9.5$ million to $\$ 10.2$ million-most of which was to be spent on mandatory pay increases. ${ }^{20}$ It cut 40 authorized positions and authorized no new money for educational or staff programs.

These facts have discouraged teachers and principals. They fear that because of asserted fiscal exigencies, the laudable intention of keeping as many children as possible in regular classes will result only in token extra support for the already overburdened classroom teacher. Principals are reportedly retaliating by resorting to the pre-Mills technique of telling youngsters, especially those over 16 years of age, that they cannot come back to school. Such behavior is of course illegal, but it may also be the only way that school-level personnel can cope with their ongoing crises. ${ }^{221}$

215. See Washington Star-News, Oct. 11, 1973, at C-1, col. 3.

216. Hearings, supra note 204.

217. Mason, supra note 214.

218. Memorandum from Merle G. Van Dyke to Dr. Hugh J. Scott, Superintendent of Schools, Additional FY 1974 Budget Request (Jan. 15, 1973) (on file with David L. Kirp).

219. Id.

220. The special education department also anticipated receiving $\$ 81,900$ in revenue sharing grants. FY 1974 Budget, supra note 210, at 6A-500-3.

221. See Platt, An Analysis of the Implementation of Mills v. The Board of 
The fiscal future remains unclear. In June 1973, shortly before leaving the superintendency, Scott proposed that the 1973-74 budget be increased by $\$ 4.075$ million. ${ }^{222}$ That suggestion demonstrated a flair for the dramatic gesture, if little else; smce school budgets must be approved by the school board, the mayor-commissioner, the city council and both houses of Congress, ${ }^{223}$ there was little possibility that the increase would be adopted during the current school year. The Board of Education unsuccessfully sought clarification of the proposal and referred the suggestion to its Committee on Curriculum, Special Education, and Education Planning, with no immediate action contemplated. ${ }^{224}$ Barbara Sizemore, the new superintendent of schools, has incorporated Scott's request into the initial 1974-75 draft budget, ${ }^{225}$ thus leaving open the possibility that new money will ultimately flow into the special education program.

Even if the budget imcrease is ultimately approved, the fimancial leadaches of special education will not cease. Special education demands more than the resources which it is specifically guaranteed in the budget. It regularly requests the Pupil Personnel Division to undertake initial evaluations, public relations personnel to inform the community of its activities and discover unserved children, the research division to do rudimentary program evaluation, and, most innportant, regular teachers and principals to assume some responsibility for "special" children. Each of these requests for help masks a budgetary drain on soine other prograin. And educators in the system, who correctly perceive that special education is garnering most of the new money which Washington has received in recent years, are increasimgly unwilling to share scarce resources. ${ }^{226}$

\section{e. The Coordination Problem: The Department of Education and the Department of Human Resources (DHR)}

Prior to Mills, responsibility for children who needed a variety of services-education, physical therapy, counseling-was divided between the school system and the District's Department of Human Resources. The school system thought that severely retarded children needed "treatment", which the Human Resources professionals presumably offer, while the Department of Human Resources thought they needed "education." The Mills decree attempted to solve this

Education of the District of Columbia: Is Due Process Being Afforded in the D.C. School System? 1, May 4, 1973 (on file with David L. Kirp).

222. Goal VIII, supra note 182 , at $36-40$.

223. Mason, supra note 214.

224. Id.

225. Fiscal Year 1975 Budget Summary, Schedule 4, supra note 210.

226. Interview, supra note 196. 
problem. The court, after noting the "lack of communication and cooperation between the Board of Education and the other defendants,"227 declared that "if the District of Columbia government and the Board of Education cannot jointly develop the procedures and programs necessary to implement this court's order, then it shall be the responsibility of the Board of Education to present the irresolvable issue to the court ...."228

Coordination sounds like a good thing-but it cannot be achieved by fiat. ${ }^{229}$ If previous failings had resulted just from unawareness of a problem, then the court's instruction to work together might indeed have sufficed to improve the working relationship of the two institutions. But in Washington, D.C., the lack of interchange between educators and human resource professionals could not so simply be rectified, as the two agencies disagreed about basic goals and their respective responsibilities. In such a situation, "coordination becomes another term for coercion . . . a form of power." ${ }^{230}$ When the precise form of coordination remains unspecified, invocation of the term "does not necessarily provide either a statement of or a solution to the problem, but it may be a way of avoiding both when accurate prescription would be too painful."231

Avoidance nicely describes what has actually happened in Washington. Thus far, the Board of Education has continued to maintain little contact with the Department of Human Resources. While the Board's September 1972 plan specified that by mid-Novenber a further filing would delineate the respective authority of the two agencies, ${ }^{232}$ that plan has yet to surface. In its September statement the Board also asserted its authority over school programs in DHR-managed institutions and stated that personnel from both agencies would participate in student evaluations. The plan also spoke of "innovative joint programs" for children who could not cope-or be coped with -in the classroom, and it promised that DHR would work with the schools to provide "therapeutic programs."233 But these statments also remain inere promises. A limited and decreasing number of DHR personnel participate in student evaluations. ${ }^{234}$ There are no joimt programs for children who disrupt classes (and currently account for

227. 348 F. Supp. at 876 .

228. Id. at 877 .

229. This discussion of the political ramifications of coordination borrows from J. Pressman \& A. WildavsKx, IMPLEMENTATION 133-35 (1973).

230. Id. at 133-34.

231. Id.

232. PlaN, supra note 175 , at 19.

233. Id.

234. Comments, supra note 193. 
most of the school system's suspension cases), although the need for the program was characterized by the superintendent as "most pressing." 235 Indeed, the DHR returned unspent all but $\$ 5,000$ of the $\$ 118,466$ budgeted for special programs to the United States Office of Education- ${ }^{236}$ a noteworthy example of noncooperation. Educational opportunities for children in institutions for the retarded and mentally ill are currently just "undergoing assessment," and the DHR has yet to use its welfare programs and health clinics to reach children with whom the school system has, at best, limited contact. ${ }^{237}$ In short, invoking "coordination" has thus far been an empty gesture.

\section{Due Process Hearings}

The Mills decree entitles every student whom the District or a parent wishes placed in a special class to a due process hearing. ${ }^{238}$ The specifics of the hearing requirement differ only slightly from those in P.A.R.C. Parents are notified of intended placement, informed that they may object at the placement hearing, and told that they may obtain legal counsel and the services of non-school professionals competent to do psychological or educational evaluations. To ensure neutrality, the hearing officer must bo an employee of the District but cannot be an employee of the school district. Unless the parents specifically request an open hearing, the session is closed. The hearing officer's decision is based solely on evidence introduced at the learing, and the District has the burden of justifying its placement recommendations or denials. ${ }^{239}$

The public does not know how the special education and disciplinary hearings have actually becn conducted, ${ }^{240}$ as most of the sessions have been closed. Apparently few parents have sought legal or professional help, ${ }^{241}$ which is simply beyond their neans. Free legal service for the due process hearings have, however, multiplied in the past year. The federally-funded neighborliood Legal Services Program, as well as Georgetown, Antiocli and Cathohic University law

235. Goal VIII, supra note 182, at 11 .

236. Id. at 11-12.

237. Id. at 12 .

238. 348 F. Supp. at $880-83$.

239. Id. at 881 .

240. Between September, 1972 and April 1973, 11 special education hearings and 61 disciplinary hearings were held. Since April, the number of special hearings has mcreased dramatically: 17 were held in September, 1973, and they are now being scheduled at the rate of two a day. Comments, supra note 193.

241. The number of parents appearing with lawyers during the 1972-73 school year was approximately six, and the present rate is estimated to be only one in ten. Comments, supra note 193, based on Ms. Wald's interview with Robert Burch, director of Hearing Officers, in Washington, D.C., Oct. 21, 1973. 
schools are providing legal counsel, and the Children's Defense Fund is planning to train lay advocates and run an ombudsmen-like, community-based service to help frustrated parents. Private schools often provide evaluations and expert witnesses where tuition subsidies are involved. ${ }^{242}$

The panel of about 20 hearing officers who hear student suspension cases and placement disputes is selected by the school district Personnel Office. Most of them are psychologists and special educators from nearby universities, untrained in the procedural requirements of legal forums. District personnel have complained that one hearing officer "quibbled over terms," while another demonstrated "hostility" toward school personnel. ${ }^{243}$ Many of the hearings are conducted as conferences, with too little attention paid to the procedural formality which the Mills decree envisioned. ${ }^{244}$ In four of the first eleven special education hearings, the school's recommendation was disapproved by the officer; in the other seven, it was either upheld or the sclool bowed to the parents' preference and changed its recommendation during the hearing. ${ }^{245}$

The concern for procedural regularity in the due process hearings does not stem solely from lawyerly attachment to formalism. Regularity helps to prevent inconsistent outcomes and provides both school officials and parents some guidance in making placement decisions. Informal conferences may satisfy the parties; they do not, however, produce a body of case law which, over time, will promote understanding of what constitutes "suitable" educational placements.

\section{Conclusion}

To one unfamiliar with the Washington, D.C. school system, it might seem easier to enforce the Mills order than the P.A.R.C. consent decree. Although its scope is somewhat broader, encompassing disciplinary problems as well as exceptional children, the decision speaks not to myriad programs managed by hundreds of agencies throughout the entire state, but to a single district and a single set of programs. But for a variety of reasons, Mills has proved at least as difficult as P.A.R.C. to implement. Only a few persons on the Board

242. Comments, supra note 193. Free community mental health centers can perform psychological assessments for parents. However, the centers are overcrowded and waits are too long. Moreover, they are run by DHR, a defendant in Mills. See Goal VII, supra note 182, at 10.

243. Memorandum to Mr. Vincent E. Reed, Assistant Superintendent, Apr. 5, 1973 (on file with David Kirp).

244. Whether the local Administrative Procedure Act applies and whether a hearing decision can be appealed for court review remain undecided issues.

245. Memo, supra note 164 , 
of Education and in the school system can be counted as whole-hearted advocates of the clianges ordered by Mills. No well-established organization such as PARC has emerged to press effectively for programmatic change. The court's decision not to appoint a master to oversee the chaotic first months of compliance left the matter wholly in the hands of sclool officials; and while many of them quite smcerely expressed their concern for the plight of previously excluded youngsters, they had neither the resources nor the organizational commitment needed to translate that concern into substantial educational reform. Looking back over the post-Mills events, one Board member wondered whether she had been "naive" in expecting the school district to comply witl the decree.

The implementation story is not wholly bleak. The proposed budget for 1974-75 contains a substantial increase for special-education prograuns; the recently-appointed superintendent appears to be dedicated to improving special education; more parents are requesting hearings and obtaining legal counsel; and an ombudsman program for parents is in the offing. The first year following Mills may have served to identify problems; new resources and new commitment to cliangeboth within and without one school system-may help to resolve them.

\section{California: Legislatively Imposed Procedural Constraint ${ }^{240}$}

\section{Introduction: Brick-Bats and Hosannas}

California has long regarded itself as a pioneer in the education of handicapped children. ${ }^{247}$ Not long after the territory became a state, it established a school for the deaf, dumb, and blind. In 1947, well before most other states, California required all school districts to provide programs for the educable mentally retarded; some districts had offered such schooling since the 1920's. Mentally retarded students were assured of an improved and expanded educational program in 1963. Educational progress, in Califorma as elsewhere, has meant the proliferation of new categories of exceptionality. In 1963, for

246. Field research for this section was conducted from November 1972 to April 1973. The researchers interviewed teachers, psychologists, specialeducation administrators, and parents in five quite different Bay Area school districts, and officials of the Division of Special Education, California State Department of Education. In addition, they observed special classes and admission committee meetings. District officials permitted the research to be done in this fashion only if naines, dates, and places were omitted. Where citation material is missing for the reason that its inclusion would breach that understanding, reference is made to this note.

247. An early report of the California Superintendent of Public Instruction notes: The 'idiot schools' have had perfect success. The blind feel the light, and the mute gains knowledge. Nor is there any young intellect so degraded but is capable of receiving not only the knowledge to read and to calculate by figures, but deep and abiding sentiments of honor and high rectitude, of conduct that mark the gentleman in after life.

Cal. Superintendent of Pub. Instruction, The fourth Annual Report 47 (1855). 
example, the state created a program for the emotionally and neurologically handicapped, allowing districts to identify up to two percent of their students as "educationally handicapped (EH)"248 and to assign them either to self-contained full-day classes (SDC) or part-day learning disability groups (LDG). Other special programs-for example, a voucher plan for children unable to succeed in any public school program $^{240}$ and a transitional education program designed to encourage the return of mildly retarded children to regular classes ${ }^{250}$-were introduced during the 1960's.

In recent years, however, California's reputation has grown tarnished. The state's treatment of severely handicapped children has evoked considerable criticism because it remains a county or school district option. While 29 California counties have chosen to create "development centers" for these youngsters, about 3,200 in districts served by such centers are currently on waiting lists, ${ }^{251}$ and an estimated 5,000-7,000 severely handicapped youngsters live in areas which provide no program. ${ }^{252}$ Sparked by the court decisions in P.A.R.C. ${ }^{253}$ and Mills, ${ }^{254}$ the California Association for the Retarded (CAR) has filed suit challenging these exclusions. ${ }^{255}$ The projected closing of four state residential institutions for the retarded which serve some 10,448 children and adults ${ }^{256}$ has also provoked considerable anxiety among those skeptical that community facilities (which are planned to replace the institutions) will ever materialize. A lawsuit filed in March 1973 seeks to halt the closing of these institutions "unless and until alternate facilities and/or procedures are established which provide equal or superior services, including at least the minimum acceptable level of . . . education . . . ..257

The strongest criticisin, lowever, was sparked by evidence of overrepresentation of black and Mexican-American students in classes for

248. "[P]upils under the age of 21 years who, by reason of marked learning or behavior disorders, or both, cannot benefit from the regular educational program. . .." CAL. Educ. Code $\$ 6750$ (West 1959), as amended, CAL. EDuc. CODE $\S 6750$ (West 1973).

249. Id. § 6870 et seq.

250. Id. $\$ 6902$.

251. Interview of David Kirp with Terry Ross, Counsel to California Association for the Retarded, in Sacramento, Cal., Jan. 19, 1973.

252. Interview with Terry Ross, supra note 251.

253. 343 F. Supp. 279 (E.D. Pa. 1972).

254. 348 F. Supp. 866 (D.D.C. 1972).

255. California Ass'n for the Retarded v. Board of Education, No. 237-227 (Sacramento Super. Ct., filed July 27, 1973).

256. Koch \& Okada, Educational Services for the Mentally Retarded Individual in California, 23 SYr. L. Rev. 1075, 1082 (1972).

257. Complaint, Revels v. Brian, No. 658-044 (San Francisco Super. Ct., filed March 22, 1973). 
the educable mentally retarded (EMR). Black and Mexican-American parents, incensed that their children were being labeled "retarded" on the basis of culturally biased, English-language I.Q. tests, ${ }^{258}$ challenged placement practices in court. In Diana v. Board of Education, ${ }^{259}$ the state consented to use Spanish-language I.Q. tests in testing Chicano children for placement in EMR classes. Two years later, in Larry P. $v$. Riles, ${ }^{260}$ a federal district court denounced the administration of standard I.Q. tests to black students as "concededly irrational"201 and barred the San Francisco school district from placing black students in classes for the educable inentally retarded "on the basis of criteria which rely primarily on the results of I.Q. tests as they are presently administered . . . ."262

The legislature also took action to correct these problems. In 1971, it declared racial and ethnic balance in EMR classes to be state policy, ${ }^{263}$ demanding that districts whose EMR minority population was 15 percent or inore in excess of the minority school population proffer an explanation. ${ }^{264}$ Companion legislation reshaped the information basis on which EMR placement was to be predicated, requiring districts to take into account developmental history, cultural background, and school achievement as well as test-measured I.Q. ${ }^{205}$ Two standard deviations below normal on I.Q. tests became the cut-off for admission into EMR classes. ${ }^{206}$ The admission process was also changed. Each district was obliged to create an admissions and discharge committee (consisting of the special-education administrator or other desiguated administrator, a special teacher, a school nurse,

258. For a report giving professional credibility to the Chicano parents' concern, see Cal. State Dep't of Educ., Spanish-Speaking Pupils Classified as Educable MENTALly Retarded (1969). The study reported the results of retesting 47 Spanishspeaking children (17 from a rural district, 30 from an urban district) with a Spanish language I.Q. test. The median I.Q. score of the group rose 13 points-from 70 to 81 , while individual scores jumped as much as 28 points.

259. Diana v. State Bd. of Educ., No. C-70-37 (RFP) (N.D. Cal. 1970).

260. Larry P. v. Riles, 343 F. Supp. 1306 (N.D. Cal. 1972).

261. Id. at 1313.

262. Id. at 1314-15.

263. CAL. Educ. Code $\S 6902.06$ (West 1973).

264. Id. \& 6902.095 .

265. Id. $\S 6902.085$. The state elevated the effect of the Diana consent decree to a statutory requirement, insisting on testing of all EMR children in the "primary home language." Id. \& 6902.08.

266. Over a half century earlier, Los Angeles maintained 13 classes for "retarded" pupils. The definition of "retardation" used then was considerably less precise and included students demonstrating "deficiencies of prior education, slowness of mind, nervousness of temperament, imperfect knowledge of the English language, or similar cause." A. Simmons, A Historical Perspective of Special Education in California, 1973 (unpubhished Ph.D. dissertation in University of Southern California library). The current two-standard-deviations-below-normal requirement can be waived only in extraprdinary circumstạnces. CAL, EDưc. Copp \$ 6902,095 (West 1973). 
and a school psychologist who had examined the child under consideration) to review the panoply of evidence amassed for each case. Parental consent was required for EMR placement. ${ }^{267}$

Since the educationally handicapped (EH) program was newer than EMR and was not plagued by the problem of racial overrepresentation, ${ }^{268}$ its shortcomings were less visible. The California Association for Neurologically Handicapped Children (CANHC), a parents' organization which a decade earhier had pressed for adoption of EH legislation, was concerned, however, about the apparent looseness of the program. While the EH criteria "neurological handicap" and "emotional disturbance" are medically recognized categories, they are also decidedly ambiguous. Each school system which chose to participate in the EH program (558 school districts and counties, enrolling most of the state's children, currently participate) defimed these terms in the context of its own organizational needs and educational capabilities. During the first flush of the program's growth, little attention was paid to the definition of "educational handicap." At both the state and local levels, program creation occupied center stage. ${ }^{269}$ But as the program grew froin 2,000 students in 1964-65 to 55,154 in 1971-72, reported abuses-inost notably, the classification as educationally handicapped of any child who provoked classrooin difficulties-led the legislature to require annual review of the "appropriateness of the placement,"270 and the State Department of Education to issue elaborate regulations specifying both program and placement procedures. $^{271}$

Several consequences of this sustamed judicial and legislative pressure on the EMR and EH programs are evident. Enrollinent in programs for the educable mentally retarded dropped froin 57,148 (1968$69)$ to $38,208(1971-72) ;{ }^{272}$ a sizable proportion of that reduction re-

267. CAI. EDUC. CODE $\S \S 6902.05,6902.85$ (West 1973).

268. In 1971, for example, 9.3\% of California's school children were black; the black EH enrollment was $8.5 \%$. Sixteen percent of the school children, but only $10.5 \%$ of the EH students, were Chicano. CaL. State Dep'T of Educ., Bureau of INTERgroup Relations, Ractal and Ethinic Distribution of Pupils in California Public SchoOLS, FALL, 1971 10-11 (1972).

269. Interview of David Kirp with Charles Keaster, Consultant, California State Department of Education, in Sacramento, Cal., Jan. 19, 1973.

270. CaI. Educ. CODE $\$ 6755.1$ (West 1973).

271. Cal. State of Educ., Selected California Administrative Code (CAC) Title 5, Provisions Pertaning to Programs for Educationally Handicapped MrNors (Special Education Memorandum EH 72-3, Mar. 3, 1972). The EH program's two-percent limitation has also been criticized by the California Association for Neurologically Handicapped Children (CANHC). A suit challenging that limitation was recently filed in state court. David P. v. State Dep't of Educ., No. 658-826 (San Francisco Super. Ct., filed April 9, 1973).

272. B. Keogh, L. Becker, M. KuKic, S. KuKIc, Programs for EdUCationally 
sulted from the reassignment of minority students to regular classes. ${ }^{273}$ Exactly what has happened to these children-their experience in transitional programs and their ability to adjust to regular classes-remains unknown. Assessment of the impact of procedural reform in both the EH and EMR prograns, the focus of this case study, poses considerable difficulties. When the legislature and the California Department of Education imposed procedural requirements, their implicit intention was to promote better educational decisions. Too little is known about the effects of any educational program to offer confident conclusions concerning the fulfillment of that goal. But reliance on procedures, rather than on substantive programmatic change, suggests that the reformers discerned a link between substance and process. They viewed decisions which centered on the needs of the child, rather than on those of the system, as presumptively better. Through observation, interviews, and the reanalysis of one survey of EH and EMR records and personnel, it is possible to assess how the placement process actually works. This assessment is not encouraging. While most districts have complied with the letter of statutory and judicial dictates, underlying issues-the etiological ambiguity of nnild retardation and educational handicap, the needs of the school organization, the vulnerability of many special-education programs-remain unaffected by the introduction of new rules. Informal processes paralleling the formal structure have emerged to accommodate legal dictates and systemic needs. In that accommodation process, the goal of child-centered decision-making has not been fully realized.

\section{The Procedural Structure}

Procedures governing placement of students in EMR and EH prograins are equally stringent. Both programs require thorough screening of any child considered for special placement by an admissions committee. The EH regulations, for example, imsist upon a developmental history of the student, a review of school experience (including classroom observation by a psychologist), tests of academic achievement and aptitude, an appraisal of background factors which might affect the student's performance, a health study, and a statement by the school psychologist that the student is performing below reasonable ex-

HANDICAPPED MinoRs: ReVIEW AND Recommendations 4 (1972) [hereinafter cited as PROGRAMs]. The results of the study, which surveyed school personnel and systematically examined school records of 24 "representative" California districts, are cited throughout this section.

273. Cal. State Dep't of Educ., Placement of Pupils in Classes for the Mentally Retarded: A Report to the California Legislature as Required by HOUSE RESOLUTION 2623 (1971). 
pectation. ${ }^{274}$ The EMR requirements, while less detailed, are similar in scope. ${ }^{275}$ These exacting demands are meant to ensure that schools place in special programs only those children who in fact satisfy the legal criteria for admission. Placements are supposed to be "the most appropriate"278 and are to identify "clearly defined instructional goals,"277 enabling the special teacher to develop a strategy which promises to return the child to a regular program as quickly as possible. Initial placement, the regulations declare, should be followed by frequent recvaluations, an annual review by the admission committee and a full case study-much like the initial study-at least once every three years. The California legislation also details the parents' role in the placement process. Before a child may be tested for placement, parental consent-preceded by a thorough explanation of the reason for testing-must be secured. ${ }^{278}$ EH legislation permits parents to designate a professional to represent the student before the admission committee; however, the representative's role is wholly advisory. ${ }^{279} \mathrm{Be}$ fore a child may be placed either in an EH or EMR class, parental consent-mased on what the regulations described as a "complete explanation" of the school's diagnosis and educational plan-is again called for. ${ }^{280}$

While the Special Education Division of the California Department of Education has issued procedural regulations elaborating upon the statutory requirements, it has done little to secure their enforcement. The Division is regulation-minded; ${ }^{281}$ its small staff (four state consultants for both the EH and EMR programs) is preoccupied with

274. Cal. Admin. Code tit. V $\$ 3231$.

275. Cal. State Dep't of Educ., Policies and Procedures for the Identification, Assessment, and Placement of Minors to Special Education Programs for the Educable Mentally Retarded, Pursuant to Education Code Section 6902, Incorporating the Provisions of SB 33 and CAC, Trtre 5, Regulations (Special Education Memorandum MR 71-1, Aug. 31, 1971).

276. Cal. Admin Code tit. V \$ 3234(a)(3).

277. Id. $\$ 3232$ (a)(1).

278. The state's sample version of a written consent form for testing a child states:

All students placed in an educationally handicapped program must be evaluated by an admission committee. In order to do a proper evaluation, certain specific psychological and medical information must be available to the committee. Thus this letter of permission is necessary to proceed in this evaluation.

Cal. State Dep't of Educ., SAmple Consent Form (August, 1971).

279. Cal. Educ. CoDe $\$ 6755.2$ (West 1973).

280. Id. $\S 6902.085$. The state's sample EH placement form states: "I (we) have received consultation regarding the learning difficulties of the child and the objectives of the program." The EMR placement form calls for a declaration that the prograin is "for pupils who have retarded intellectual development."

281. See generally Jaffe, The Effective Limits of the Administrative Process: A Reevaluation, 67 HARV. L. REv. 1105, 1113 (1954). 
responding to voluminous local requests for guidance on points of law and on the nnechanics of such matters as requesting additional state funds or waivers of statutory requirements. For several reasons, the Division has not undertaken to monitor or evaluate special-education programs. The size of its staff and uncertainties concerning suitable criteria make evaluation difficult. And because the results of evaluations nuay not always be positive, the enterprise is risky for a division whose political capacity to negotiate forcefully with school districts is decidedly limited.

The Division does carry out ad hoc reviews of local practices at the insistence of vocal and well-organized local parents' groups. ${ }^{282}$ But the scope of these reviews is limited to the precise subjects of the parents' coinplaint. In one district treated in the case study, a review which took place in early 1973 focused exclusively on fiscal management questions and did not consider the very critical problem of implementing procedural requirements. ${ }^{283}$

\section{The Procedural Reality ${ }^{284}$}

In each of the five California districts studied, ${ }^{285}$ the formal procedural requirements for placement of EH and EMR students have become standard operating procedure. District-wide (or in the largest districts, regional) admission and discharge committees hold meetings, although reports persist of children placed in special classes without benefit of admission committee review. Signed parental consent forms are routinely solicited prior to placement, even though gaps in the schools' records could be found. But in each district, determinations that a child be labeled "special" and the decision as to which special program he ${ }^{286}$ should be placed in are made informally. The formal process usually functions to ratify those decisions.

282. In one case, the parents' group sought to pressure the Division into responding by contacting state legislators and publicizing their grievances. Interview with Robert Whitenack, Director of Special Education, Berkeley Unified School District, in Berkeley, Jan. 15, 1973.

283. The Division's proposed California Master Plan to Special Education [see text accoinpanying notes 305-08 infra] would inarkedly change its role.

284. See note 275 supra.

285. The five districts studied were Berkeley, Mill Valley, Oakland, Richmond, and San Francisco. While these were not selected as "representative" but because they were close at hand, variations among them in terms of racial and social class mix of the student population, and size and administrative structure of the district appear sufficient to warrant making some general conclusions on the basis of the sample. District officials permitted extensive observation of special education classes and admission committee meetings on the condition that observations not be linked to specific districts or individuals. For that reason no further identification of the source of observations is reported.

286. "He" is used advisedly. The survey of California's EH and EMR programs 
This section describes the workings of a "typical" informal system. Such an approach risks sacrificing complexity for coherence; it minimizes the considerable differences in style and behavior among (and even within) the five districts studied. In one district, for example, the EMR director runs the program with an iron hand, insisting both on what the director terms the "imtegrity" of the program and strict adherence to legal procedure. In another, the atmosphere is strikingly informal; procedural regularity is sacrificed to flexible educational programming. Yet despite these differences, the process by which a child comes to be recognized as "special" and the organizational pressures which foster such a process appear not to vary greatly. ${ }^{287}$

\section{a. Identifying Special Children}

The suspicion that a child may belong in an EH or EMR class first arises in the regular classroom setting: a particular student may fall hopelessly behind his classmates; sit mutely in class; or, most typically, cause classroom disruptions. The teacher attempts to cope with such aberrant behavior by snatching small amounts of time for special instruction, trying to lure the child into class discussion, or imposing a firm disciplinary regime. If the problem persists, the teacher may discuss it with colleagues who previously taught the student or seek help from the principal. If the problem seems intolerable-and definitions of what is tolerable deviation from expected behavior vary markedly from teacher to teacher-the teacher may ask the primcipal to have the child tested for special placement.

If the principal's primary concern is to support the regular teaching staff, he is likely to call in the school psychologist for testing. ${ }^{288}$ But other factors may influence his decision: his pohtical power within the school system and the chances of his recommendation prevailing in a dispute with special-program personnel; the availability of special resources in the district; and the feasibility of managing the problem informally by transferring the student to another regular class or placing him on reduced-day instruction in the same school. If, for example, the principal knows that the district's speeial classes are filled

notes that 70.1 percent of the students (58.2 percent in EMR, 80.9 percent in EH) are male. Programs, supra note 272, at 108.

287. "Appear" is used deliberately, for respectable data are hard to come by. As one group of student commentators las noted, "The [Southern California] districts studied lacked an astonishing amount of material essential to a proper evaluation . . . ." K. Delay, S. Heath, L. Thara, J. Jacks and L. Wagner, California's Program for Educational Minors: A Study 16 (1971) (available from Program in Public Policy Studies, Claremont, Cal.).

288. Robims, Mercer, and Meyers in The School as a Selecting Labeling System 5 J. School Psychology 270 (1967), report that 90 percent of all special education referrals are made by the teacher-principal team. 
for the year, he may ask for the teacher's patience, offering her a more comphant group in the coming year.

Some principals are chiefly concerned with the welfare of the crisis-provoking child. They may have misgivings about the competence of the special teachers who serve the school's population or they may beheve that many misconduct problems can be corrected within the regular class. But unless the teaching staff shares such attitudes, the principal cannot readily act on them. In a school whose teachers cannot or will not respond to the varied challenges that some students regularly pose, it is politically difficult for the principal to reject requests for special placement. A principal who, in the words of one teacher, "can get things done" is one who solves problem cases by removing them from the regular system's jurisdiction and responsibility.

As the law contemplates, the teacher-primcipal conference generally precedes special-class placement. In some schools, however, special teachers are willing to accept (on a trial or part-day basis) students who have not been reviewed by special-education professionals. Such an approach may well be pedagogically sound in some cases. Where, for example, a child has difficulty in distinguishing certain letters but can otherwise cope in regular classes, a good special teacher can often quickly remedy the problem. Bureaucratic red tape is thereby circumvented, help provided with dispatch, and the possible stigmatization of a fornal label is avoided. In one district studied, EH smallgroup sessions regularly include $\mathrm{EH}$ and regular students, an arrangement that appears to benefit both groups. But im ghetto schools, where the perceived need for special services routinely outstrips their availability, ad hoc placements tend to be made for more children for longer periods of time and for reasons less pedagogically laudable. One school psychologist who works in several ghetto schools reports: "I've never even evaluated half of the EMR students in one school. They just wind up in the program."

If the principal and teacher concur that a given student should be placed in an EH or EMR program, the school psychologist is called in. His influence is dominant. While nonpsychological evidence (a health history and home background study, for example) is legally required, the psychological evaluation is crucial. In order to justify specialprogram placement, the psychologist must find the student to be either retarded (performing two standard deviations below normal on an I.Q.

289. In another school in the same district, a student assigned himself out of EH program. He decided that he was ready for regular work, and is performing admirably; as far as the admission committee is concerned, he is still an EHI child. See note 275 supra. 
test) or doing less-than-expected work. Psychologists, like everyone else attached to special programs, are overworked; they are assigned to several schools and serve as many as 5,000 students. While they are theoretically accessible to all the children in a school district, the demands made upon them to identify and screen special-program children often mean that they only have time to do individual psychological assessments. Since they are assigned to more than one school and frequently switch assignments, they have little opportunity to work regularly with particular classroom teachers or come to understand variations in school culture. Moreover, psychologists view themselves as most competent to do individual evaluations. They feel they lack the skills to work in the classroom setting and the time to follow through on any advice which they might give. From the teachers' point of view, psychologists are often perceived as outsiders whose advice is offered condescendingly. A survey of EH and EMR teachers in 24 representative California districts reported that while three-quarters of special teachers viewed psychologists as "helpful," they said that testing represented "the major type of assistance. . . . Diagnosis, psychological support, classroom observation, counselling, and program recommendations were all relatively low frequency responses."290

\section{b. The Parents' Role}

Before the psychologist can test a student, someone in the schoolusually the classroom teacher or a social worker-secures parental permission. Although parental acquiescence is theoretically preceded by an explanation of the testing procedure and the school's reason for requesting the tests, permission is often secured without parents' knowing what they are consenting to. The permission is but one document among several that parents are asked to sign. Sometimes "to save time," as one psychologist put it, permission for placement is obtained during the same visit as permission for testing, even though the school does not know into what special program (if any) the student should be placed. Some parents resist giving permission for testing or placement. Refusals by black parents are estimated to run as high as ten percent, especially in the EMR program. From the viewpoint of special personnel, the model parent neither resists nor discusses-he does what the school asks him to do without challenging the rightness of the professional's judgment. Parents who do raise questions or object to school-recommended placeinents are frequently dismissed as "nuts" or "trouble-makers." While 88 percent of California's EH and EMR teachers viewed parents as "no problem," only 14 percent considered

290. Programs, supra note 272 , at 79,82 . 
them helpful ${ }^{291}$ and just 6 percent recommended that parents' role in special education be increased. ${ }^{202}$

Special educators have developed strategies to cope with the relatively rare instances of parental resistance. The reluctant parent is barraged with evidence of his child's poor schoolwork as proof of the need for special school attention. If that fails, school professionals can threaten to leave a child back or, more distressingly for some parents, put the student on reduced-day or home instruction. The persistent parent who is convinced that his educational objections should prevail does, however, have some political resources at his command. ${ }^{293}$ $\mathrm{He}$ can bombard the special-education office with phone calls and visits, and in general make such a nuisance of himself (in the eyes of the special educators) that peace on any terms becomes appealing. He can call upon parent groups such as CANHC and CAR for help. ${ }^{204}$ The threat of a lawsuit may encourage the district to buy him off. ${ }^{205}$ Parents can also press their grievances upon the state education department; while that agency does not routinely monitor programs, it has occasionally responded to parental pressure by conducting an investigation.

\section{c. The Admission Committee}

i. How decisions are made. The school district's admission committee renders the formal placement decision, relying primarily on the psychologist's report, classroom and home background information, and pertinent medical evidence. In some districts the committee does at-

291. Id. at 85 .

292. Id. at 90 .

293. In the fall of 1972 , one of the districts studied established parent-schoolcommunity task forces, whose mandate included review of all special-education practices. In operation, however, the task forces functioned quite differeutly. Meetings were dominated by powerful veteran special-education officials. Their presence prevented the task forces from considering any basic program changes and cut them off from significant parent or community organization contact. While some of the task force recommendations may ultimately be adopted, parent members concluded privately that only an organized and direct appeal to the board of education-such as California Association for Neurologically Handicapped Children (CANHC) had undertaken-promised any substantial change. See note 275 supra.

294. While the California Association for the Retarded (CAR) and the California Association for Neurologically Handicapped Children (CANHC) tend to focus on statewide legislative and administrative issues, those groups or their local affiliates have on occasion aided irate parents in negotiating with local school officials. See note 275 supra.

295. In one of the districts studied, a parent was able to obtain an educational voucher for his child by threatening to sue the district. Fear of litigation over classification practices, prompted by the increasing nninber of lawsuits, is pervasive in California. One EMR administrator volunteered the fact that his placeinents were "lawsuit-proof." See note 275 supra. 
tempt a thorough evaluation of the children who come to its attention. In three of the five districts studied, however, the decision in fact resulted from bargaining which took place prior to the committee meeting.

Those involved in the evaluation process-the psychologist, the school social worker, the principal, and the regular teacher-frequently meet inforinally to resolve any differences. For each of the participants consensus is preferable to a public disagreement, for a prior consensus denies the committee, inost of whose inembers have no first-hand knowledge of the particular child, any effective decision-nnaking role and removes the possibility of confrontation among professionals. Although this approach tends to limit the function of the admission commmittee in a fashion not contemplated by the legislature, the informality that it preserves is not necessarily bad. Since no special-education supervisors are present to nionitor the discussion, nore free-wheeling and candid exchanges inay be possible. Yet infornality may carry a price. Because the collegial, professional relationships of these participants, of which these nreetings forin only a part, depend to some extent on goodwill and reciprocal provision of support, the plight of a particular child may beconie less important than developing satisfactory stays against confusion. ${ }^{296}$

Two styles of admission committee behavior became apparent in the field studies. In the three large districts studied, the committee devoted an average of two and one-lralf minutes to each case presented. That brief time was sufficient for the psychologist to read his reportwhich described children in such terms as "talkative and distractable," "timid but emerging," "having conflict of values with those of the school," and "suppressed ego and development coniplicated by neurological deficits"-and for the psychologist to attach the appropriate label, e.g., "minimal brain dysfunction," "neurological, liyperkinetic." As one special-education director stated: "We are not a decision-making board. We just need to put the thing into legal language." In these three districts, then, the admission committee simply ratifies decisions already reached informally. In two other districts the admission committees atteinpt a more thorough review. Disagreements among school professionals are argued out at the conference; rejected recommendations and divided votes are not uncommon. Yet even in those meetings the data on each child are simply too scanty for careful, reasoned judgments; whether space in a particular program is in fact available frequently proves the determinative factor. As one psychologist noted in exasperation: "We've got to get our signals straight. In [another] school, they're putting kids into the EH program just like

296. Since we were unable to sit in on these sessions during the field inquiry, these reinarks should be treated as speculative. See note 275 supra. 
those we're reinoving over here." The EH supervisor responded, "The schools will do whatever they can get away with." The vagueness of the EH criteria encourages such variation; it also enables the admission committee to conclude that a child who "doesn't fit anyplace else" is, by definition, educationally handicapped.

Even the most conscientious admission committee cannot fully carry out its job of making appropriate placements. For one thing, the school organization does not give it sufficient information. Perhaps, given the state of the educational art, sufficient information cannot, in inany cases, be collected. Yet the admission committee meetings do serve a purpose. They afford participants the opportunity to air grievances about particularly difficult children and about parents who, by refusing to send their truculent youngsters to residential institutions, take up valuable $\mathrm{EH}$ spaces. Much like other professional gatherings, they give school professionals an opportunity to impress their superiors. In one district einbroiled in a series of controversies concerning the $\mathrm{EH}$ program, the special education director treated the meetings as a means of assessing the caliber of the system's school psychologists. ${ }^{207}$

Although parents are legally entitled to send an "advisory" representative to the EH (but not the EMR) admission committee 1neeting, that right is seldoin exercised. In the estimation of school officials, this confirms that parents are not interested in what the school is doing. But unless a parent has read the pertinent legislation, he would be unaware of this right; it is not routinely revealed to parents. Special educators, while expressing their willinguess to meet with a parent or representative at the admission committee, fear that the presence of an outsider might force bargaining further underground. The coinmittee's handling of children, one program supervisor reinarked, is "just too impersonal for the average person to understand . . . it would appear cruel." The presence of such an outsider imight also pose a threat to the committee's usual style of operation and, more basically, to the credibility of its decisions.

ii. Parental consent and educational "prescription." After the admission committee reaches its decision, parents are to be informed of its recommendation and asked for their written consent. ${ }^{208}$ This requirement is desigued to afford parents the opportunity to discuss educational specifics-not "is my child 'exceptional?" but "is this the best program for him?" In the committees whose operations were observed, however, consent had uniformly been secured prior to

297. These are, in Robert Merton's terms, "latent functions" of the admission committee. R. MERTon, Soctal Structure 51 (2d ed. 1957).

298. CAL. EDuc. CoDE $\S 6902.085$ (West 1973) (EMR); Id. $\$ 6755.3$ (EH). 
the meeting. Indeed, one special-education director in a district which devotes minimal attention to individual cases at the committee meeting refused to consider a case until the school psychologist had obtained parental permission for placement. The permission-before-decision approach gives the committee a blank check to place a student wherever it wishes, and negates any significant parental role. Even the language of the consent form which parents sign discourages candid discussions between parents and educators. Despite state admonitions for clarity, one district asks parents to consent to "LDG placement," which only the most astute parent will realize permits placement of their child in a learning disabihity group, a part-day program for educationally handicapped children.

As local districts interpret the law, parental consent must be obtained only for the first special placement. A student placed in a part-day special class can subsequently be reclassified as a full-time special student or placed on home instruction without further parental involvement. While the parent is empowered to withdraw his consent, few parents either know about or exercise such a right. In short, the written parent-consent requirement does not noticeably affect the districts' decision-making processes. In most school districts obtaining it has become routine. Where parental resistance can be anticipated, school districts may even assign students to special classes without consent. For example, while a survey of 24 school district EMR files indicates that 79 percent of all children enrolled in EMR programs had signed, parent-approval forms in their files, in school districts with high concentrations of black children the consent figure dropped to 55 percent. ${ }^{299}$

The admission committee's job ends with the prograin placement deeision. Although the committee is required by state regulations to develop educational prescriptions- to indicate with some precision not only what problems a child is having, but also what might be done to overcome them-such advice either is not offered or is rendered at a useless level of generality (e.g., "improve reading skills," "improve writing skills," "small-class instruction"). There is no effort to delineate specific learning disabilities or to construct learning strategies which will be most effective. In the California survey, only 27 percent of EH and EMR teachers reported that prescriptions were "useful," while 42 percent had never received any prescription. ${ }^{300}$

299. Programs, supra note 272, at 132 . School psychologists suggest that one reason for failure to secure parent approval is difficulty in contacting parents who work during the day, move frequently during the school year, and are distrustful of any contacts with the public sehool.

300. Id. at 56. 
Given the heavy time burdens which admission committee meetings impose on special educators, it may be unrealistic to expect collective attention to issues more complex than placement. But the committees' apparent unwillingness or incapacity to imstruct the special teacher causes considerable frustration. In one admission committee, the EMR supervisor turned to a special teacher and asked whether she could handle a particular child. "Sure," the teacher rephed, "if you can let me know what you expect me to do with him." Lacking any assistance, pedagogical decisions are made in "eclectic" 01 fashion by the teacher, the one professional in the special-education system seen as responsible for what happens in the classroom..$^{302}$

While California's EH and EMR regnlations treat imitial placement as only one stage in a constant, ongoing process of review, the press of new business frequently means that the initial inquiry will be the only instance when a case receives serious consideration. There are, however, counter-pressures which do create opportunities for reevaluation. Since the EH program is, by statute, limited to two percent of the student population, the demand for new placements encourages "de-certification" of EH students in districts which have already reached that ceiling. The retesting of all EMR students, mandated by law, has reduced enrollment in that program. Some children do flourish in the smaller, more individualized EH and EMR classes, and are eventually recommended for discharge from the special program. Yet 40 percent of the EH and EMR students surveyed had not been evaluated since their placeinent. ${ }^{303}$ The typical educationally handicapped child has been enrolled in a special program for 2.30 years. His counterpart in the educable mentally retarded class has been enrolled for 4.53 years; 14 percent have becn in EMR classes for more than eight years. ${ }^{304}$ These children have in fact become "special children"; little systemic incentive exists to treat thein otherwise.

301. Id. at 46.

302. Id. at 20. This pattern also discourages the thoughtful regular teacher from seeking admission committee help with a particularly difficult child. One such tencher frequently brought cases to the committee, only to be told: "It sounds like you're doing a good job. Keep up the good work and let us know how it is going." Such a teacher will have already tried all logical techniques, and hopes that the committee's specialized expertise will provide useful advice. The only alternative which the committee can offer is special placement; it lacks the capacity to support efforts which maintain difficult students in regular classes. If the child is not "exceptional" within the committee's understanding of that term, he cannot be assisted by the committee.

303. Id. at 140. Of those who were reevaluated, 60 percent were reviewed by the admission committee, 22 percent were retested by school psychologists, and 17 percent were reviewed by classroom teachers. Id. at 140-41.

304. Id. at 126. Most children are not classified as retarded until third or fourth grade. Thus the longest possible stay in an EMR class is eight or nine years. Since the survey sample included students still in elementary school, it suggests that a sizeable (and undetermined) percentage of EMR placements are in fact permanent. 
4. Prospects for Change: The California Master Plan for Special Education

Those who criticize special-education programs in California do so for a variety of reasons. They score the present tangle of special programs whose mandates are both uncertain and overlapping, and whose financing seems even capricious. They note the absence of any systematic prograin evaluation, or even the collecting of data upon which sensible evaluations might be conducted. They charge the state with failure to provide some form of education to all children by continumg to exclude thousands of handicapped youngsters most in need of assistance. They worry about the stigma associated with certain special-education labels, notably that of "retarded." They continue to be unhappy about the marked overrepresentation of black and Chicano students in programs for the mildly retarded. And they are concerned about the nearly complete separation of regular and special education.

In response to these criticisins leveled at special-education programs, California's State Department of Education has been working for the past two years with various local school officials and university experts to construct a "California Master Plan for Special Education." ${ }^{305}$ The Plan proposes sweeping changes in the financing, governance, and operation of those programs. Categorical programsthe educationally handicapped prograin, for exainple-are replaced in the Master Plan by a single broad category encompassing all children who need special help. Districts and counties are charged with the task of undertaking coinprehensive planning for these youngsters. They are required to develop a variety of approaches ranging from the utilization of "resource teachers" working in regular school settings to the operation of special classes and institutions. The Master Plan calls for regular evaluation, not only of each child but also of school programs. It imsists upon "maximum interaction with the general school population . . . ." 308 and encourages "the return of children with exceptional needs to the regular school program in the shortest time possible . . ...307 requiring districts to provide "explicit due process procedures"308 for those who feel they belong in (or out of) special programs. Primary responsibility for operating and evaluating special programs is left with the districts and counties; the state assumes the role of momitoring and supervising evaluation efforts.

The Master Plan is by no means assured of adoption. It will

305. Cal. State Bd. of Educ. \& Cal. State Dep't of Educ., Proposed California Master Plan for Special Education (September 1973).

306. Id. at 14.

307. Id. at 15 .

308. Id. at $17 \& 27$. 
cost more than present arrangements, and the California legislature has not been noticeably inclined to increase special-education funding in recent years. It contemplates nnajor changes at each administrative level-local, county, and state-and the prospect of those changes has already elicited resistance. By removing programunatic labels, it risks offending parent groups which have sought to protect the interests of their children through insisting on clearly demarcated programs. But even if the Master Plan is approved in precisely its present form, the effect it will have on the informal aspects of special-education placement is far from clear. The very flexibility it seeks to implement unay well be used by local districts as a device to maintain practices which have functioned tolerably well. Neither the language of the Plan nor the historic role of the state special-education division suggests that such efforts would encounter substantial resistance. In short, the proposed Plan speaks of change without providing any real incentives to accounplish it.

Such a dour view reflects an understanding that school classification practices did not spring up by accident, but, rather, energed in response to perceived organizational needs. It may well be, as one student of organizational behavior suggests, that "[c]areful targeting of major factors that support routines-such as personnel, rewards, information, and budgets-can effect major change over time." Master Plan, if adopted, may also enable those in the special-education system who presently chafe under its rigidity and compartmentalization, who view their professional roles as compromised by organizational and fiscal constraints, to create alternative arrangements. But as to that possibility - and the durability of the informal organizational behavior described in this section-it is too early for reasoned prediction.

\section{The Case Studies: Some Concluding Observations}

These three case studies offer no precise ineasure of the impact of laws which secure either substantive benefits (the right to an "appropriate" education) or procedural protection for children viewed as handicapped. The very design of the inquiry (which considers both court decisions and legislation, and assesses quite different kinds of handicapping conditions) as well as the avowedly anecdotal nature of the research underscore the need for caution in interpretation. But some conclusions-more accurately, ideas which warrant further consideration-can be advanced.

First, change in legal standards, whatever its source, does not en-

309. G. Allison, Essence of Decision 94 (1971). 
sure altered school behavior. The limitations of judicial policy-making-stemming from, among other factors, a structural mability to shape disputes, control resources, select among policy alternatives, or monitor or readily revise rulings to adjust to altered experience-have been frequently remarked. ${ }^{310}$ Legislatures are also subject to many of these same limitations. And both legislatures and courts depend on others-state and local school officials and their subordinates-to effectuate their mandates. To the extent that standards promulgated by either branch of government seem impractical or unfeasible to school personnel, those standards may be ignored or altered in operation.

Second, some changes are easier than others to accomplish through legal mandate. In Pennsylvania, for exaniple, a coordinated effort by education officials and an active parents group identified 15,000 children who had previously been excluded from public schools. The accomplishment is notable but its significance should not be overestimated. Finding excluded children does not require school systems to undergo organizational change; rather, it calls for a clever advertising campaign and for funds to conduct a school census. More basic changes, such as inplementation of procedural safegnards or the insistence on "appropriate" educational placement, come more slowly. They require a reshaping of the special-education progran and a reexamination of the range of regular school offerings.

Reform also becomes more difficult to accoinplish when more than one agency's practices are called into question. This is typically the case with respect to the severely handicapped, a group historically excluded from the public schools and provided with only minimal care by state welfare agencies. The judicial command that these organizations "coordinate" their activities masks a host of bureaucratic difficulties.

Third, resistance to change does not result from the obduracy of misguided school officials. The sorts of changes that P.A.R.C., Mills, and the California legislative reforms contemplate would require wholesale reevaluation of school structures and organizational roles, and consequently threaten everyone in the systein. The special-education program seeks to protect its status by rigidly distinguishing its task from that of the regular progran. The regular program relies on special classes to handle those with whom the classroom teacher cannot cope. Special teachers, isolated from school decision-making both with respect to individual cases and school policy, feel reluctant to enter the regular school domain to which they have historically been denied

310. See, e.g., Kurland, Equal Educational Opportunity: The Limits of Constitutional Jurisprudence Undefined, 35 U. CHI. L. Rev. 583 (1968). 
access. The school psychologist, whose days are presently taken up in giving I.Q. tests to crisis-provoking children, lacks both the time and the skills to offer sustained attention to a greater variety of school problems. The principal needs to satisfy teachers' demands to remove those who create classroom disorder. The proposed reforms, if implemented, would require alteration of each of these patterns of behavior. $^{311}$

While the status quo is not wholly praiseworthy, it does offer a functional solution to those charged with teaching and administering schools. If "appropriate" placement-the Mills and P.A.R.C. requirement-can be viewed as demanding only a choice ainong existing alternatives, the status quo is generally preserved. If California's admission committees, designed to provide a procedure which makes "appropriate" placements more likely, can operate to confirm decisions made at a less visible level, they need not enlarge the responsibilities which schools have historically undertaken. Although these practices may subvert the ultimate goals of the judges and legislators, they may also constitute the only way school officials know how to do their job.

Fourth, the case studies indicate some of the conditions needed to bring about the ultimate goals of legal change. Clearly, pressure stronger than the mere existence of a legal requirement is required. Parent groups may exert such pressure; its force and direction will depend on whom the parent group represents, and on whether its commitınent endures over time. ${ }^{312}$ If special educators are securely positioned in the school system, they too may push for reform. But sueh strength is most likely to result from system-wide concurrence concerning the goals of the special system, and those who have it may well resist reform. A court-appointed special master possesses sufficient clout to affect program direction, if the impermanence of the position does not encourage bureaucrats to wait him out. A strong commitinent by school administrators, particularly at the state level, to adhere to regnlations may induce at least formal rationality. None of these factors ensures that marked organizational change will occur. But they do provide support for incremental, limited reforn. Without the presence of at least some of these elements, legally-mandated alteration in special-prograin practices may not have even nominal effect.

Fifth, the impact of law may vary with the nature of the group whose claims are being pressed. Children with mild and difficult-to-

311. See generally, Wildavsky, The Self-Evaluating Organization, 32 PUB. ADMIN. REv. 509 (1972).

312. See C. Des Jardins, How to Organize an Effective Parent Group and MoVB BuREAUCracies (1971). 
diagnose handicaps make demands upon the school quite different from those advanced by children with more potentially debilitating problems. Variations in children's backgrounds are similarly pertinent: a child detached from any family life-living on the streets or in a succession of foster homes-may be harder for schools to cope with than a nominally similar child whose family is deeply concerned about his well-being. These subtleties are ignored by court decisions such as Mills, which treat all children excluded from school, whether because they are autistic or delinquent, as posing common problems. Common remedies-whether procedural or substantive in nature-may miss the mark in particular kinds of cases.

Sixth, these case studies focus on the education of exceptional children, and that focus nay well be too narrow. Defining an "appropriate" education ultimately must be a task which encompasses the entire school system. The rigidities and constrained choices which epitomize special education in even the most progressive states also characterize regular instruction. The particular problems associated with special education may simply be unresolvable unless attention is directed to organizational factors which make present practices appealing to school personnel. Such sweeping reform is, however, nowhere at hand. In the meantime, it is worth considering whether any narrower intervention, couched in procedural terms, merits serious consideration. The concluding part of this Article addresses that question.

\section{III}

\section{Exploring Procedural Modes of Special Classification}

Both the P.A.R.C. ${ }^{313}$ and Mills ${ }^{314}$ decrees establislied procedural requirements to protect and support substantive rights, and these requirenents were discussed in fairly standard due process language. Detailed procedures have likewise been prescribed by regulation and statute in Califorina. But procedural mandates can be frustrated by organizational inertia, and our field studies suggest the need for further examination of the usefulness and limitations of various procedural modes. This Part will explore and suggest tentatively what procedures should be adopted for classification, in light of the lessons learned from the Pennsylvania, Washington, D.C. and Califorma experiences. Our poimt of departure, however, is not the P.A.R.C. and Mills problem of complete exclusion of children from the public school system. Instead, this Part will explore broadly the whole process of classification

313. Pennsylvania Ass'n for Retarded Children v. Commonwealth, 334 F. Supp. 1257, 1260-61, 1266 (E.D. Pa. 1971); 343 F.2d 279, $303-05$ (E.D. Pa. 1972).

314. Mills v. Board of Educ., 348 F. Supp. 866, 880-83 (D.D.C. 1972). 
by which children are identified as having special-education needs and placed into special education programs.

We realize that the inclusiveness of this approach entails certain hazards, as there is a risk that generalized discussion of "procedures for special classification decisions" will suggest that there is one best set of procedures. We emphasize, however, that different procedures may be appropriate for different special-education decisions, and that procedures must be tailored to the requirements of each program.

The discussion will begin with some general observations about due process and its application in the context of classification for special education. We will note some of the main reasons for limiting proceduralization and, hopefully, will produce a healthy skepticism about the appropriateness and utility of applying strict notions of procedural due process to classification decisions. We then will describe a representative "model" of procedural due process as it has been developed judicially and will imdicate in more detail the advantages and drawbacks of applying this classical model to special education decisionmaking. Various alternative, inodified forms of due process will then be suggested-for "due process" is a concept of almost limitless elasticity. Although the term can signify a relatively fixed set of procedures (the classical due process inodel), it can also encoinpass any process that is considered appropriate or "due" in a particular setting. Very often what is "due" means what is constitutionally required; however, as we do not consider our inquiry to be bound by constitutional limits, we will ultimately use "due process" to signify whatever procedure seeins most likely to achieve desired ends at an acceptable cost, in the light of all appropriate considerations. Finally, Part III concludes with a brief treatment of various related matters that cannot readily be assimilated into a discussion of a due process model and alernatives.

We would like to anticipate one of our most fundamental conclusions because it is a critically important guide to all that follows: Based on what we now know, no one set of procedures or one procedural model appears to be appropriate for all special-education decisions. On the contrary, there is a virtually unlimited nuunber of choices, each of which involves particular costs and benefits that must be weighed agaimst each other. To determine costs and benefits, various fact and value judgments must be made about the consequences of any classification decision. For example, a determmation that classifying a child as einotionally or mentally retarded creates a serious stigma is a factual judgment; a determination that it matters that such stigmatization occurs is a value judgment. Factual conclusions will, of course, vary from one district to another-for exanple, the retardation label 
will be much more stigmatizing in some communities than in others; and certainly values will differ both within and without any community. This raises the question of whose values should govern-who should have the power of choice. Are values to be determined at a national, state, or local level?--by the usual political inachinery, by some groups or professionals, or by the courts? We do not attempt to answer these questions, but do try to isolate and examine these and other considerations that must underlie the choice of appropriate procedures.

\section{A. Due Process: Costs and Benefits}

What constitutes "due process" is flexible and highly dependent upon context. Justice Frankfurter, discussing the constitutional dimensions of due process, described the nature of the concept and the many considerations that must underlie the prescription of proper procedures:

Fairness of procedure is "due process in the primary sense." ... "[D]ue process" cannot be imprisoned within the treacherous limits of any formula. ... Due process is not a mechanical instrument. It is not a yardstick. It is a process. It is a dehicate process of adjustment inescapably involving the exercise of judgment. . . . The precise nature of the interest that has been adversely affected, the manner in which this was done, the reasons for doing it, the available alternatives to the procedure that was followed, the protection implicit in the office of the functionary whose conduct is challenged, the balance of hurt complained of and good accomplished-these are some of the considerations that inust enter into the judicial judgment. . . . .315

Procedural due process in its most classical form is represented by the procedures designed to prevent a criminal defendant from being wrongfully convicted..$^{310}$ But procedural due process has also been applied in a variety of contexts outside the criminal law-to juvenile justice, ${ }^{317}$ discharge from government employment, ${ }^{318}$ student discipline, ${ }^{310}$ revocation of motor-vehicle licensing, ${ }^{320}$ and distribution of welfare benefits. ${ }^{321}$ In all these contexts, due process is invoked be-

315. Joint Anti-Fascist Refugee Comm. v. McGrath, 341 U.S. 123, 161-63 (1951) (Frankfurter, J., concurring).

316. See, e.g., Pointer v. Texas, 380 U.S. 400 (1965); Gideon v. Wainwright, 372 U.S. 335 (1963).

317. In re Gault, 387 U.S. 1 (1967).

318. Perry v. Sindermann, 408 U.S. 593 (1972); see Greene v. McElroy, 360 U.S. 474 (1959).

319. Dixon v. Alabama State Bd. of Educ., 294 F.2d 150 (5th Cir.), cert. denied, 368 U.S. 930 (1961).

320. Bell v. Burson, 402 U.S. 535 (1971).

321. Goldberg v. Kelly, 397 U.S. 254 (1970). 
cause of two fundamental elements: (1) government action threatens to cause deprivation of a vital interest such as personal freedom, college enrollment, or welfare payments; and (2) the facts which might lead to the deprivation are disputed (e.g., whether the defendant "broke and entered" at night, whether the student participated in an unlawful demonstration, or whether the welfare recipient had received incoine in excess of permitted amounts). Due process, then, requires some proceeding that will protect the imdividual's asserted interest by ensuring careful determination of controlling facts. Due process proceedings are also designed to achieve other goals: to ensure that facts will be measured against appropriate criteria; to guarantee that decisions will be made carefully and impartially; to afford opportunity for participation to affected persons; and to preserve public confidenee in the integrity of governmental decision-making.

To determine whether procedural due process is a helpful concept in the context of special education classification, we must first examine the nature of the interests affected by a classification decision and the type of factual determinations that must be niade. In the other situations mentioned above where procedural requirements are imposed, it is clear that an adverse factual determination will result in the invasion of a vital interest: for example, a finding that a defendant wrongfully entered a louse will result in his loss of freedom. But whether governmental action classifying a student as needing special education will result in the infringement of a vital interest is often unclear. If a special education decision has the effect of depriving a student of all opportunity for pubhic sclooling, a vital interest is invaded and the case for extensive procedural protection is strong. ${ }^{322}$ If the claimed effect is harmful stigmatization, again there is a substantial injury warranting procedural safeguards. ${ }^{323}$ But if the complaint of the student and his parents is that reassignment to a special program deprives the child of "regular" education, it is not clear that there is any

322. See Mills v. Board of Educ., 348 F. Supp. 866 (D.D.C. 1972); Pennsylvania Ass'n for Retarded Children v. Commonwealth, 334 F. Supp. 1257 (E.D. Pa. 1971) (jurisdiction retained), 343 F. Supp. 279 (1972) (separate opinion with aniended stipulation and amended consent agreement). See also Brown v. Board of Educ., 347 U.S. 483 (1954); Dixon v. Alabama State Bd. of Educ., 294 F.2d 150 (5th Cir.), cert. denied, 368 U.S. 930 (1961). See generally Buss, Procedural Due Process for School Discipline: Probing the Constitutional Outline, 119 U. PA. L. REv. 545, 575-76 (1971); Coons,, Clune \& Sugarman, Educational Opportunity: A Workable Constitutional Test for State Financial Structures, 57 CALIF. L. REv. 305, 373-89 (1969). To compare exclusion from school with terminatiou of other government benefits see Goldberg v. Kelly, 397 U.S. 254 (1970). See generally O'Neil, Of Justice Delayed and Justice Denied: The Welfare Prior Hearing Cases, 1970 SuP. CT. REv. 161.

323. See Board of Regents v. Roth, 408 U.S. 564, 573-74 (1972); Wisconsin v. Constantineau, 400 U.S. 433 (1971); Jenkins v. McKeithen, 395 U.S. 411, 427-28 (1969); Joint Anti-Fascist Refugee Comm. v. McGrath, 341 U.S. 123 (1951). 
deprivation of a vital, protectible interest. It is clear that the child is given something different. But is it more, or less, or is the change neutral? Transfer to a special program can be regarded as conferring a valuable benefit: the child receives arguably more meaningful, and often more expensive, education, and he may receive nonacademic advantages such as removal from an anxiety-ridden school environment and stimulation from a new one. But the state's or school's claim that special assignments are beneficial is self-serving, and its characterization should not be accepted as conclusive any more than any other state-imposed limitation on freedom that is justified as being for the good of the affected person. ${ }^{324}$ In fact, a special-education program is likely to offer a narrower, less demanding curriculum than the regular program, leading to inore limited life choices for special students. The curriculum may be taught by teachers unable to get regular jobs, and it may have no measurable beneficial effect on the student's academic performance. The student may suffer nonacademic detriment by losing friends and familiar teachers and experiencing dislocation; or by incurring the inconvenience of a longer bus ride or the mability to come home for lunch. Thus, whether a classification decision (that does not exclude or stigmatize) is beneficial, detrimental, or neither will depend upon a wide range of variables including the accuracy of the evaluation of the child, the educational soundness of the special program, the adequacy of its resources, and the attitude of the child's parents.

A child is harmed-his vital interest in the best available education is invaded-only when in the light of variables such as these the decision made is not "correct." Since it is not clear, therefore, that substantial deprivation will result from a classification decision, there undoubtedly will be resistance to incurring the costs of affording procedural safeguards to a child and his parents.

Not only is the existence of protectible mterest in classification decision-making more ambigious than in the typical context where strict procedural requirements are imposed, but the nature of the questions that must be answered is unlike the decisive factual questions normally raised when a vital interest is threatened. Typically, a due process proceeding is used to determine the truth when there is a choice between fact $A$ and fact $B$, the only two possibilities. The defendant either was in Los Angeles on May 12, or he was not; either he committed murder in the first degree, or herdid not. Due process procedures-notice, hearing, right to cross examine-are specifically

324. Cf. Buss, Procedural Due Process for School Discipline: Probing the Constitutional Outline, 119 U. PA. L. Rev. 545, 558, $571-72$ (1971). 
designed for determining the truth when such either/or questions are in issue.

Ideally, the special-education decision answers a question that is strikingly different from a yes/no fact question. When special classification is considered, the question should be what is the educational program that would best fulfill this child's educational needs? This question plainly does not ask for a choice between only two possible alternatives; it asks for a selection of the most appropriate from an unlimited range of alternatives. It requires a judgment about a plan of action-a managerial decision. This is not the sort of problem that due process procedures are designed to resolve.

In reality, however, educational decision-makers do not have an unlimited range of alternatives to choose from, and the questions actually asked and answered do not differ so dramatically from those resolved in adjudicative proceedings. Classification decisions involve the "fitting" of all children into a limited number of categories on the basis of the answers to three distinct questions: (1) Does the child need "special education" that cannot be provided in the "regular" program? (2) If so, what are the child's educational needs? (3) Given the present limited array of programs and resources, which one best meets the child's needs? ${ }^{325}$ The first of these questions is like those typically answered through due process procedures: it asks for a yes/no determination of fact. And before one can properly answer any of these three questions, many subordinate factual issues must be resolved. For example, the decision-maker might inquire: Does the child demonstrate an ability to get along in a social context? Was the only basis of special classification the result of a standard paperand-pencil test? Are more blacks than whites with comparable records classified as special? Such subordinate questions may be crucial to the final classification decision, and often do require a choice between conflicting assertions of fact or a judgment whether some fact is important. ${ }^{326}$ These questions clearly could be resolved in adjudicative

325. The authors do not claim that present practice explicitly divides the classification decision into these three questions; rather, such a division is consistent with actual practice. In fact, the question asked often is the right (ideal) question: what educational program does this child need? But because limited resources, categories, and insight make that question unanswerable, a very different question is answered: what is available that seems reasonably related to what the child needs? The actual process of decision entails coinparative assessments of available programs, including the regular one. Once it is acknowledged that the regular program has a presumptive edge, see note 359 and accompanying text infra, it is proper to conceptualize the threshhold question as whether or not the child needs a special education program. In addition, some systerns set certain conditions precedent that must be satisfied before a child can be specially classified. See Car. Educ. CODE \$ 6902.085 (West 1973).

326. Larry P. v. Riles, 343 F. Supp. 1306 (N.D. Cal. 1972), is a case where fact issues were dispositive. The court proceeded on the basis of the following legal proposi- 
proceedings, even if the ultimate judgment about classification did not lend itself easily to solution by adjudication. The result would be "more correct" facts on which to base a judgment and increased public confidence in the decision-making process. ${ }^{327}$

From an examination of the nature of the interests at stake and the judgments that are required, it is not clear that traditional forms of procedural due process are appropriate for classification decision-making. The expense of formal proceedings may not in all cases be justified by any resulting benefits; and adversarial proceedings are not designed to elicit in a coherent fashion all the various kinds of information that must go into a managerial decision about how best to fulfill a child's educational needs. But there are benefits other than careful fact-finding associated with due process, and we shall briefly consider their relevance to special education classification.

First, when facts are explored in a formal due process proceeding, they are fully exposed for analysis and contradiction. It is arguable that due process would contribute to improving the content of special education because the reasons for each classification would be out in the open. If the reasons were invalid, they would be exposed, and the resulting public disapproval would force adjustments in a salutary direction. But any such changes would proceed slowly and modestly. Moreover, even though due process procedures might work effectively to underline program needs, there would be a cost, since drawing attention to what is needed but cannot be produced for lack of knowledge or resources might produce destructive tensions. Second, decisions made with due process procedures are ordinarily accompanied by a statement of reasons. Such statements articulating the grounds for the classification decisions might result in greater consistency, though much will depend upon the creation of a coherent set of criteria for each type of special classification and upon the ability of the opinion writer to express the reasons clearly. Third, it is clanned that due proc-

tion: If (i) blacks (or members of other minority groups) were classified as "retarded" and placed in special classes at a rate disproportionate to their proportion of the relevant school age population, and (ii) there is no convincing evidence that blacks are generally less intelligent than whites, the classifications are uncoustitutional. Once that proposition was accepted, both (i) and (ii) raised factual yes/no questions-were blacks disproportionately classified as retarded?; is there convincing evidence that blacks are generally less intelligent?-that were determinative of the outcome of the case.

327. There appears to be a continuing lack of confidence that correct fact decisions are being made by educators and their professional advisors. People suspect that decision-makers may be hurried, incompetent, ignorant, careless, or acting in bad faith. "Bad faith" as used here does not mean prompted by viciousness or malice, but only that the decision-maker is affected by interests that may be inconsistent with those of the child. For example, a principal may feel some pressure to assign a student to a special education program if that student is a source of trouble to a particular teacher who, consequently, becomes a source of trouble to the principal. 
ess procedures increase the competence and impartiality of decisionmaking. Whether this improvement would take place depends, in part, upon the present quality of special-education decisions, which vary from place to place. It is clear, lowever, that classification decisions at the present time are inade by persons who liave interests whicl often conflict with those of the child and which are likely to shape some decisions improperly. ${ }^{328}$

A fourth claimed benefit is that due process facilitates participation in determining one's own fate. But whether there would be such a benefit is indeterminable. The child cannot speak for himself, and his parents might be too uninterested, hostile or ignorant to speak in his best interest. Furthermore, increased participation will make a difference only if it genuinely has some bearing on the outcome of the decision, which it is likely to do the more important expert opinion becomes.

Finally, due process is said to increase public confidence in the integrity of decision-naking. But the net effect in the classification context is ambiguous. If doubts about the validity of special-education decisions stem from public distrust of the particular persons making the decisions, lack of understanding about what is really going on, lack of participation in the process by persons championing the child's interests, or rumors about expedient placenients, due process should tend to increase public satisfaction. If, however, the trouble lies rather in the lack of resources or of viable progranis from which to cloose, public confidence in the results of classification decisions will not be restored by introducing due process procedures. And there is a risk that over-emphasis on procedure will divert frontal attacks on the deficiencies of special education itself.

Before turning to a more detailed appraisal of a special-education due process model, one final general observation merits attention. Due process is an expensive decision-making mechanism-in terms of money, time, energy, and distraction. Plainly, the costs of providing due process must be carefully measured against the benefits of improving the quality of decisions and protecting children for possible serious harin. ${ }^{329}$ And of course, if sonie due process procedures are justified,

328. See text accompanying note 26 supra.

329. Under the pattern of decisions concerning the constitutional right to procedural due process, the Supreme Court sometimes has determined that a threatened interest is too insubstantial to merit constitutional protection at all. See, e.g., Board of Regents v. Roth, 408 U.S. 564, 570-71 (1972); Cafeteria Workers v. McElroy, 367 U.S. 886 (1961). At other times, the Court has indicated that the protection required must be tailored to fit both the interest affected and the institutional burden that would result. Boddie v. Connecticut, 401 U.S. 371, 378 (1971); see Hannah v. Larche, 363 U.S. 420, 442 (1960). Both types of judginents are significantly influenced by the costs of holding due process proceedings. 
their costs should be minimized where possible, consistent with providing an acceptable level of decisional control.

\section{B. A Due Process Proposal}

A standard due process model includes the following features: Every person subjected to or threatened by serious adverse official action is entitled to participate at a hearing held after adequate and timely notice, and is entitled to be represented by counsel and to present evidence, make arguments, and cross-examine adverse witnesses. The proponent of official action has the burden of proof, the decision is reached by applying established criteria to the evidence presented and recorded at the hearing, and the decision is made by a qualified and impartial tribunal. A statement of reasons explaining the administrative decision is made public, and judicial review of the decision is available.

In order to consider the implications of applying due process procedures in the special-education context, it is necessary to make two assuinptions: first, that the initial classification decision made by the school administration is regarded as subjecting the student to serious adverse consequences; and second, that the school administration's decision is subject to review (rejection, approval, or modification) by a "panel" consisting of one or more persons not affiliated with the public schools. This review would involve a hearing with the concomitant rights described above. Various aspects of this model will be discussed in turn.

\section{Mandatory Versus Discretionary Proceedings}

Certain procedural safeguards may be constitutionally required, as P.A.R.C. and Mills suggest. ${ }^{330}$ But, putting possible constitutional rights to one side, it seems clear that any system that entitles every student specially classified by a school administration to extensive procedures for review raise at least two basic problems. First, the volume of cases required to be heard might be intolerable. Second, many decisions would be uncontested, and it is impossible to know that the "right" cases would actually receive full review.

It is obviously desirable to provide every classified student with a "day in court," and the burden of doing so can be reduced by a kind of informed self-interest. Parents would not subject themselves to the wear and tear of due process liearing if there were little cliance of their clrallenge prevailing, and scliool administrators would, in time, cease to make classifications unlikely to withstand the scrutiny af-

330. See notes 313-14 supra. 
forded by a due process hearing. But the precedents necessary for such self-regulation might be slow in developing and even slower in gaining acceptance, and there is still the possibility that the wrong cases may too often be the ones that are challenged by the children's parents. Adequate notice and counseling could alleviate but not eliminate this problein. For its part, the administration might tend to avoid review either by "settling" a case (and thus perhaps compromising the child's interests) or by not making the classification in the first place where the ultimate basis of its judgment is intuitive and thus difficult to document or prove. ${ }^{331}$

A screening system would make full review of the school administration's initial decision a matter of discretion rather than right, somewhat along the lines of the Supreine Court's certioriari jurisdiction. If volume were a problem, a screening process could select only important cases and clearly such a process could alleviate the "wrong case" problein. But screening, not surprisingly, raises many troublesolne issues: Who initiates the exercise of discretion? What material is examined in order to exercise discretion? What criteria should control the exercise? And does screening result in unequal treatment? If parents inust petition for discretionary review, there are again problems of relying upon parental initiative. This defect can be rennedied, however, if initiative rests with someone in addition to the parents, and several possibilities exist: the review panel itself, a single member of the panel (perhaps on a rotating basis), a staff worker assigned to the panel, or possibly someone distinct from the panel, such as an employee in the Department of Education.

If review were discretionary, it would be essential that some uniform and streamlined record or report of the administrative action be available as a basis for exercising discretion. The record might include a statement of the case, the administrative conclusions, and the reasons for the particular decision. If parents were permitted to petition for review, the record subinitted by the parent should also mclude argumentative or relevant factual material. Based on this record, the review panel would select certain classification decisions for full hearings. The criteria for selecting these cases should be very general, and the discretion to grant or deny a hearing very broad. The standard should be whether there is substantial likelihood of error, or whether questions of general importance are raised. "Importance" would at-

331. One P.A.R.C. hearing became particularly long and acrimonious, and there have been no further referrals from the school district involved. This sort of avoidance seems an inevitable aspect of any requirement that the administration justify its action to an independent body. It will be minimized as a problem mainly by recognizing intuitive grounds of decision as valid to the extent it is feasible to do so. 
tach to a recurring factual or legal issue on which precedent would be useful, or to certain categories of cases involving a high risk of error or stigma or a relatively low expectation of improvement.

Any system that selects certain cases for hearing and screens out others raises problems of equal treatment. But there are at least two means of avoiding unfairness even with discretionary review. First, the criteria used in selection for review, though broad, must be applied consistently. Second, there must always be some opportumity to be heard at the level of the original decision. This opportunity would be mucli more limited than that afforded by review panel learings, but it slould imclude at least clear notice and the opportunity for the parent to appear before the person or persons responsible for making the classification decision prior to the time that decision is made.

\section{Participation}

A person miglit be permitted to participate in the process of making a classification decision for three reasons: (1) The person might be able to present factual information that bears on the decision. (2) The person might represent a point of view that slould influence the decision. (3) It might be beneficial to that person to be allowed to participate. In most due process contexts, the right of a person threatened with adverse governmental action to be present at the liearing is assumed. But the personal appearance of the student himself is probably not constitutionally required, and, in formulating classification procedures without regard to constitutional limitations, the decision whether to require, allow, or prevent participation by the student being classified sliould be made on the basis of real advantages and disadvantages. Relevant inquiries are whether the child will understand what happens at the proceeding, whether the child has any contribution to make to the decision, and whether it is beneficial or liarmful to the child to be present. These questions must at least mitially be answered by a psycliologist or psychiatrist, and probably on a case-bycase basis.

The remainder of this discussion will assume that the child does not attend the hearing but that a parent ${ }^{332}$ is present and, in effect, stands in for the child. It is wrong, of course, to assume that the parents' and the child's interests will never vary. Sometimes they clearly will conflict. ${ }^{333}$ For exainple, a parent may want to "get rid of"

332. The word "parent" as used throughout this Article includes a guardian or other legally responsible parent-substitute.

333. See, e.g., Heryford v. Parker, 396 F.2d 393 (10th Cir. 1968) (discussion of waiver of counsel by parent who institutes proceeding to cause child's civil commitment). See generally Buss, Procedural Due Process for School Discipline: Probing the Constitutional Outline, 119 U. PA. L. REv. 545, 587-89 (1971). 
a child he considers a nuisance or a burden, or might resist appropriate and beneficial placement in a particular special education program because he fears some resulting stigma. Often such conflicts cannot be detected, ${ }^{334}$ and, to some extent, parent-child conflicts must simply be tolerated. Nevertheless, the governing procedures should include a provision for appointment of a guardian ad litem to represent the child's separate imterests when there is evidence of a significant conflict of imterest.

We have assumed participation by parent-substitutes, but it is also possible that an organization-perhaps one such as PARC created to protect the interests of retarded children, or an organization which protects important rights generally, such as the American Civil Liberties Union-might want to intervene. Although the deciding panel should have discretion to control such intervention, permission should be granted hiberally. Controlling statutes or regulations should state that intervention is to be permitted whenever rights of children not being classified are likely to be affected, or whenever there is reasonable ground to believe that the organization petitioning for intervention would enhance the quality of the record on which a decision is made. Unless the legal staff of the intervening organization is representing the parent directly in a lawyer-client relationship, an intervener's contribution is likely to be based not on facts peculiar to the child being classified, but on facts about similar children and programs in operation, and an analysis of the standards or criteria relevant to decision.

A different approach to "who participates" would involve the creation of an independent government agency to protect and further the interests of special-education children. Many variations for such an agency are possible, and the following is only a suggestive outline: The agency would be independent of the school administration, and would participate in the classification decision either on its own initiative or upon parental request. The agency would have its own staff, which would participate at every stage froin mitial consultation to judicial review. It would make its own policy decisions about whether and how to pursue cases to informal settlement, decision, or judicial review, but would not have the ultimate decision-making power. Either the decision-making panel and the independent agency would be completely distinct entities, or the agency and the panel would be separately functioning subdivisions of a more inclusive entity.

Creating an independent "children's agency" would plainly involve economic costs. It would also mean an additional bureaucratic

334. Compare the discussion of the Allegheny School conflict, in the text accompanying notes 110-11 supra, where parents strongly defended a seemingly inadequate school. 
structure which would acquire a life and a set of interests of its own, and could minimize the role of the parent and the parent's preferences concerning the child's education. But such an agency would also have its benefits. It would tend to increase efficiency; it would eliminate the capricious element created by reliance on parental initiative; it would increase consistency of policy and result; and it would be likely to have more clout than the parent in dealing with the school administration.

Participation must be considered not only in terms of "by whom," but also of "when." A typical sequence leading to special classification would be: (1) The student is identified as meriting special attention-he perhaps seems unresponsive, inattentive, or unmanageable. (2) The student is observed, and perhaps discussed, by teaclier and psychologist, teacher and counselor, or teacher and principal. The school psychologist conducts tests. (4) The student is evaluated on the basis of tests, observation, and acadeinic performance. (5) The student is placed in some special program. (6) The student is reevaluated. Throughout the present discussion it is assumed that apphicable procedures are made available at stages (4) and (5) and, perhaps, (6). But, participation by parent, child, concerned organization, or independent agency is possible at any of these stages. Furtherinore, additional informal stages allowing participation might be added, such as the "pre-hearing liearings" that have evolved under the P.A.R.C. ruling in Pennsylvania. ${ }^{385}$

\section{Notice}

Perhaps the most basic requirement of procedural due process is that a person be given notice of proposed action with sufficient clarity and in sufficient time to enable him to prepare a case for presentation at the hearing. In the special education setting, the act triggering right to notice would be the school administration's initial decision to classify a child as "special." If the parents have a right to participate at the hearing before the panel, they should receive notice that fully describes the purpose of the hearing-including the range of possible placements that might result-and the basis of the school administration's decision-including what tests were given and their results, classrooin or other observations, opinions of classroom teachers, and the inferences drawn froin all such evidence. The parents should have this notice long enough in advance fully to prepare for the hearing. If participation includes the right to be represented by counsel, there should be sufficient time for the parents to engage a lawyer and for

335. See text accompanying note 147 supra. 
the lawyer to assemble appropriate evidence, including locating expert witnesses. The notice should clearly state the parents' rights-to be represented by counsel, to consult an independent educational psychologist, or the like. And if the hearing is discretionary, the parents should be informed of the method and criteria for the exercise of discretion. $^{336}$ Similar notice must be given to any other person or organization also having a right to participate.

In addition to formal notice when the school's decision to classify is made, the parents ideally should be notified of all preliminary actions taken by the school administration when considering the possibility of classifyimg a child for special education. ${ }^{337}$ This notification should be in the nature of counseling. Even though the parents have no right to participate at the preliminary stage, they have a strong interest in knowing facts that vitally affect their child's education and future; and all administrative action should be described in sufficient detail to inform the parents of its basis and potential consequences. ${ }^{338}$ The parents will sometimes be able to influence the classification process even at this stage by making oral or written communications with the school or by seeking imdependent legal, psychological, or other assistance. Furthermore, only if the parents know what is happening to their child and why, are they able to help the child with explanation, understanding, and compassion. Notification forces the school to articulate and explain what it is doing, to the clearer understanding of all parties concerned.

336. Statutory and court-mandated schemes for special-education classification commonly require notice to parents prior to the determinative hearing. The P.A.R.C. decision seems to require the most exhaustive notice requirements, ranging from a statement of reasons for and alternatives to the proposed action, to an exhaustive examination of procedures that will be followed and courses of action available to the parent. 343 F. Supp. at 303-04 (amended stipulation). See also Mills v. Board of Educ., 348 F. Supp. at 880-81.

337. Not only should the notice to the parents be complete, but it should provide the necessary information in a manner that is sensitive and understanding. In some instances notices have been harsh, blunt and, consequently, extremely upsetting to parents. Oral statement of J. Hearson, Right To Education Officer, at July 10, 1973, Masters' hearing, under the P.A.R.C. decree.

338. All notices should be written to be understandable by a layman. If there is still a reasonable basis for believing that the parent will not fully coinprehend the notice, the school administration should take affirmative steps-a telephone call or a hoine visit to explain it. If the parent does not speak English fluently, it may be necessary even to use a translator. The Califorma statute, for example, requircs that the proposed classification decision be communicated clearly to the parents in the home language.

Permission docunuents for individal psychological evaluation, and placements, shall be written im English and in the language of the parent or guardian. Conferences and notices to inform the parent or guardian of the nature of the placement process, the committee conclusion and the special education program shall be in the home language of the parent or guardian.

CAL. Educ. CODE, § 6902.085 (West Supp. 1973). 
Of course, school administrators might resist fully informing parents in all cases. Often the school would prefer not to be "bothered" by parental intervention. Administrative convenience should never be a ground for withholding information, but in some cases the school will have a reasonable basis for believing that informing the parents will detrimentally affect the child. And, notifying the parents will tend prematurely to crystallize a decision which otherwise would remain tentative and reversible. Therefore, while ordinarily parents should be informed sooner rather than later, school authorities should not be precluded froin making a reasonable, good-faith, professional judgment to delay timing of first notification to parents that their child is being considered for special classification.

In addition to parental notice, it is important to consider what other persons or organizations should be informed of a pending hearing. Notices should certainly be sent at the parents' request to lawyers, child-advocate organizations, or others representing or assisting the parents. But because the involvement of a child-advocate organization may be indispensable for a meaningful protection of the child's rights, it may also be desirable to notify such an organization without awaiting parent initiative. This could be done in several ways. Interested child-advocate organizations could be required to "qualify" or register with some state agency, such as the Department of Education. The grounds of qualification could be kept very simple, the purpose of registration being primarily to determine which organizations wanted to participate. The hist of qualified organizations would be distributed to all schools, and school administrators would notify the organizations of all special education hearings, supplying the name and addresses of parents. An organization could then choose to contact the parents; but, to protect the child's privacy, it would participate only with the parent's consent. Alternatively, to provide greater privacy protection, the school could include information concerning qualified organizations in the parent's notice, and leave it to the parent either to contact an organization or ask the school to do so. Or the notice could state that the organization listed would be informed within a stated period of time unless the parent requested notice to be withheld.

As a check on school administrations that might subvert or simply disregard notice requirements, ${ }^{339}$ the decision-making panel should determine whether the parent received actual notice at all appropriate stages in the classification process. If the parent does not appear when entitled to do so, the panel should not proceed until satisfied that the

339. See discussion of the California experience in text accompanying notes 29899 supra. 
parent had received and understood timely notice concerning the nature and purpose of the proceeding and his rights in relation thereto. Should information subsequently come to the attention of the panel imdicating that the parent had not in fact been notified adequately, the panel should have discretionary power to conduct a partial or complete rehearing. ${ }^{340}$ If the parent does appear but the panel determines that adequate notice was not given concerning some prior stage in that process, the panel should take that failure into account im assessing the initial classification decision and perhaps expand the scope of the hearing to reconsider the action taken at that stage more completely than would otherwise be appropriate.

\section{Professional Consultation and Services}

In criminal proceedings, one of the most fundamental aspects of due process is the right to counsel. The right is so iniportant that criminal defendants who are financially unable to obtain legal assistance on their own are provided state-appointed counsel at the state's expense in all felony cases $^{341}$ and in inisdemeanor cases where the possibility of incarceration exists. ${ }^{342}$ The right of counsel, sometimes including the right to state-appointed counsel, has also been recognized as an essential ingredient of due process in many non-criminal areas, ${ }^{343}$ and was included as part of the required procedural due process in both P.A.R.C. and Mills. ${ }^{344}$

340. Compare the judicially mandated procedure in P.A.R.C., which requires that all notices be sent by certified mail if they are not given in a conference. If notice is sent by certified mail, the parent can return an enclosed card within 10 days to request hearing. If the card is not received, the board may assume that the right to a hearing has been waived. 343 F. Supp. at 304 .

341. Gideon v. Wainwright, 372 U.S. 335 (1963).

342. Argersinger v. Hamlin, 407 U.S. 25 (1972).

343. See, e.g., Goldberg v. Kelly, 397 U.S. 254, 270 (1970); See generally Buss, Procedural Due Process for School Discipline: Probing the Constitutional Outline, 119 U. PA. L. Rev. 545, 603-15 (1971); O'Neil, Of Justice Delayed and Justice Denied: The Welfare Prior Hearings Cases, 1970 SuP. CT. REv. 161, 178, 195-200.

344. P.A.R.C. provides the right to representation "at the hearings by any person of [the parents'] choosing, including legal counsel." 343 F. Supp. at 305 (amended stipulation 1972). Mills requires that the parent be informed of "the right to be represented at the hearing by legal counsel. . .." and that indigent children be assisted in obtaining (though apparently not guarantced as of right) legal counsel. 348 F. Supp. at 881.

The child shall have the right to a representative of his own choosing, including legal counsel. If a child is unable, through financial inability, to retain counsel, defendants shall advise child's parents or guardians of available voluntary legal assistance including the Neighborhood Legal Services Organization, the Legal Aid Society, the Young Lawyers Section of the D.C. Bar Association, or froin some other organization.

Id. at 881, \13(e)(6). A Massachusetts statute, effective in 1974, specifies that if there is a disagreement between parents and school over the placennent recommended in the initial evaluation, the parents are entitled to a hearing before the Department of Education. MASS. GeN. LAws ch. 71B, $\S 3, \pi 12$ (Supp. 1973). The procedures 
If special-education classification decisions are stigmatizing, detrimental, highly susceptible to error, and open to influence by improper motives such as racism or the desire to "dump" troublesome students, then there is a strong case to be made in support of the P.A.R.C. and Mills decisions granting the right to assistance of counsel. If these assumptions are firmly believed, the case easily justifies the further right to state-furnished counsel for imdigent children. But if these assumptions are rejected or only tentatively believed, the riglit to counsel argument is weaker-or at least more complicated.

The primary justification for participation by counsel is the lawyer's ability to present evidence in an orderly fashion. The value of that contribution looms large when factual issues are important and the consequences of their resolution are potentially extremely damaging. A lawyer may also contribute to the classification procedure by articulating the child's position in favorable terms relative to the governing standards or criteria. More generally, a lawyer may lielp to give the proceedings order and objectivity even though he is representing one party; his status and ease in formalized proceedings might have a valuable balancing influence where most of the significant participants may be aligned on one side. ${ }^{345}$

It can certainly be argued that lawyers would be detrimentalthat they would tend to make proceedings too formal and costly, that they would be intimidating to other persons, or that they would interfere with the proper presentations of psychological evidence by forcing the psychologist's evaluation into a question-and-answer format. None of these consequences is inevitable, nor necessarily very likely. They may, to a considerable extent, be consequences of the adversary nature of the due process hearing itself. The asserted lawyer-caused disadvantages may just be imdications that lawyers would indeed make the hearings work according to their design and purpose. And both the costs and benefits of lawyerly participation can be significantly affected by the quality of the presiding panel and the degree of control it is willing to assert.

If, after costs and benefits were weighed, lawyer participation were rejected, the parent would still be free to consult a lawyer in ad-

provided in this hearing are to conforn with those of the Massachusetts Administrative Procedure Act. MAss. GEN. LAws ch. 30A (1966). The Massachusetts Administrative Procedure Act does not explicitly guarantee a right to counsel in the hearings, but it is implicit that all of the procedural protections provided are done so in the framework of representation by legal counsel. See Mass. GEN. Laws clr. 30A, § 11 (1966). The decision sliould be "mailed upon request to each party and to his attorney of record." Id.

345. For a more complete statement of the lawyer's potential contribution in a related context, see Buss, Procedural Due Process for School Discipline: Probing the Constitutional Outline, 119 U. PA. L. Rev. 545, 603-15 (1971). 
vance of the proceeding. Perhaps he should also be able to retain the lawyer during the proceeding for consultation though not for representation. If, on the other hand, lawyer participation is permitted, the parent should be able to retain instead a non-lawyer to represent his interest, ${ }^{346}$ as lawyers might be scarce or expensive. The tasks of marshalling facts and articulating a position could be performed by law students or persons with paralegal training.

Once the right to representation by retained counsel is given, the question arises whether counsel should be provided by the state for those who lack the resources to provide their own. The question is particularly important because classification for special education tends to correlate with poverty: denying state-appointed counsel might preclude representation by counsel where it is needed inost. Nevertheless, the question whether the state should provide counsel is very different from the question whether a participant should have the right to be represented by retained counsel. To decide that a parent inay be represented by a lawyer he hires, one need decide only that the presence of a lawyer will not be detrimental to the proceeding. But state-appointed lawyers add significantly to the cost of hearings, and to require appointment one inust inake a judgment that the extra cost is necessary to offset a substantial disadvantage of unrepresented parents that could result in great injury to a child.

In criminal and juvenile proceedings, due process sometimes requires the right to additional professional assistance besides that of counsel. ${ }^{347}$ Clearly, classification proceedings require the professional services of educational psychologists, for psychological evaluation of tests and other data is by far the most critical input into the classification decision. Although examination by school-employed psychologists should always be a condition precedent to special classification, it is crucial that the parent have the right to present the evaluations of independent psychologists. Psychological analysis and evaluation involves professional judgment that is, to some extent, not susceptible to objective proof or challenge. But no one contends that all psychologists would decide the saine case alike. And since some of the most serious challenges to special-education classification are the absence of trustworthy criteria, the inconsistency of tests rehed upon, and the failure to use a sufficiently broad range of data in making classification decisions, expert testimony can obviously be essential to support a challenge to the school's initial determination. The importance of the right to present such evidence has fortunately been recognized. Under

346. See provision of P.A.R.C. decree, note 46 supra.

347. See Goldstein \& Fein, The Indigent Accused, the Psychiatrist, and the Insanity Defense, 110 U. PA. L. REv. 1061 (1962); Note, Right to Aid in Addition to Counsel for Indigent Criminal Defendants, 47 MINN. L. REv. 1054 (1963). 
the P.A.R.C. decision, a parent can introduce at his own expense "other expert testimony" at the hearing, including, apparently, reports or oral testimony by educational psychologists not einployed by the school. A Massachusetts statute that will become effective in September 1974, goes further and specifies that a child is entitled to an imdependent evaluation. ${ }^{348}$ The Mills decision states that notice sent to parents or guardians must include the address of a local diagnostic center where the child can be independently evaluated. ${ }^{349}$

The more difficult question is whether this professional assistance must be provided to the indigent parent at state expense. The benefit to the parent seems clearer than that resulting from assistance of counsel, and the potential disadvantage to the effectiveness of the hearing insignificant. In our opinion, there will be serious disagreement over the child's need for special education primarily only in cases involving mildly handicapped children. It would be feasible, therefore, to provide that in those cases a parent has the right to psychological services, provided by the state if necessary, unless the decisionmaking panel makes an affirmative finding that such services could not reasonably be expected to have any substantial effect on the classification decision. In cases involving a determination of the need for special education for seriously handicapped children, a desirable and feasible system would be to provide psychological services to indigent parents only if the panel makes an affirmative finding that such services can reasonably be expected to have a substantial effect on the evaluation decision. We would choose to put all placement decisions (in contrast to need decisions) in the second category and thus place the presumption against state-appointed psychological services in the absence of a panel determination. But this position is closely related to the behief that the panel should have much flexibility in making placement decisions generally.

\section{Presentation of Evidence and Cross-Examination}

Both Mills ${ }^{350}$ and P.A.R.C. ${ }^{351}$ provide for extensive rights to pre-

348. Upon completion of said evaluation the child may obtain an independent evaluation from child evaluation clinics or facilities approved by the department jointly with the departments of mental health and public health or, at private expense, froin any specialists.

MASS. GEN. LAws ch. 71B, \& 3, T 10 (Supp. 1973) (effective Sept. 1974).

349. Such notice shall ... inform the parent or guardian that the child is eligible to receive, at no charge, the services of a federally or locally funded diagnostic center for an independent medical, psychological and educational evaluation and shall specify the name, address and telephone number of an appropriate local diagnostic center. . . .

348 F. Supp. at 880-81 (T 13(e) (2) (e)).

350. 348 F. Supp. at 880 (TT 13(e) (2) (f), (10), (12), (13)).

351. 343 F. Supp. at 304-05 (TIT 3(f), (r), (s)). 
sent evidence and cross-examine witnesses, ${ }^{362}$ with no suggestion that these rights should be conditional or qualified in any way. But, as discussed previously, there is a question whether the sort of factual dispute that gives rise to evidentiary rights and rules is characteristic of what must be decided in a classification proceeding.

The right to present evidence and, especially, the right to crossexamine witnesses, ${ }^{353}$ are extremely important and useful safeguards that contribute to the correct resolution of factual disputes. They would, therefore, be appropriately incorporated in classification procedures if factual disputes were frequently raised. But disputing a classification decision which is based on an assessment of the child's condition or ability usually raises complicated problems of psychological interpretation and educational policy rather than simple factual issues. It is possible, though not likely, that the parents will have some clear factual issue to prove, such as that the child's test score was improperly recorded, or that the conditions under which a test was given were improper, or that the person who administered a test showed a racial bias toward the student. But more likely, the parents will argue that information such as observed social behavior was erroneous. This might entail a factual dispute about what the child actually did, but it is more likely to entail a challenge to the inferences drawn from the observed phenomenon. What inference can be properly drawn from such observations is indeed still a question of fact. But it is a fact of a different kind. Its "truth" depends largely upon expert interpretation. Although the basis of the expert's opinion should be open to challenge, psychological interpretation is not readily amenable to proper presentation via traditional modes of questioning and cross-examination. If the parents accept as correct the facts and inferences drawn but argue that the classification decision was wrong because special education programs do not "work" or because a student will be "better off" im the regular classroom, he is really challenging the underlying policy judginents on which special education is premised. Values, rather than facts, are disputed, and a resolution will not significantly be assisted by enabling the parent to prove or disprove facts. ${ }^{354}$

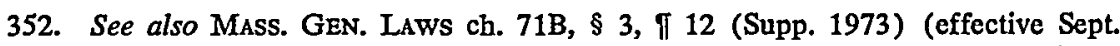
1974). Under the pending Massachusetts scheme, when a parent refuses the educational program proposed on the basis of the initial evaluation, the parent may request a hearing to inquire into "the evaluation of the child and the appropriate education program," and this hearing is to be held in accordance with the provisions of the Massachusetts Administrative Procedure Act which expheitly provides for the presentation of evidence and cross-examination. See MAss. GEN. LAws, ch. 30A, $\$ 11$, II 3 (1966).

353. Cross examination has been called "the greatest legal engine ever invented for discovery of the truth." 5 J. WIGMORE, EVIDENCE $\$ 1367$, at 29 (3d ed. 1940).

354. Of course, the fact/value judgment dichotomy can be overstated; facts do 
There are costs associated with permitting extensive presentation of evidence and cross-examination or witnesses, which must also be reckoned. The main disadvantage is the consumption of time: presenting evidence through oral questions and answers is a slow process. Cross-examination can be an unpleasant experience for witnesses, which creates or heightens tensions and possibly deters some persons from testifying at all. ${ }^{355}$ These disadvantages are significant and should not be incurred unless there is real countervailing benefit.

If, overall, it is determined that fact issues are not liable to be significant at classification hearings and that therefore the costs of permitting full rights to present evidence and cross-examine witnesses are too high, then these rights might be dispensed with. Or, the extent of permissible presentation of evidence and cross-examination could be left to the panel's or presiding officer's discretion on a case-by-case basis. As an irreducible minimum of parental participation, parents should be able to make some written or oral response to the school administration's evidence and conclusions, ${ }^{356}$ with respect to both the threshold decision to consider special education, and the content of the placement decision itself.

\section{Burden of Proof}

To establish criminal liability or make a finding of delinquency that would lead to a juvenile's confinement, the government must prove

underlie value judgments. But a distinction has been made between "adjudicatory facts," to which cross-examination is uniquely relevant, and "legislative facts," or policy determinations, to which it is not. See $1 \mathrm{~K}$. Davis, ADMINISTRatrve LAw $\$ \$ 7.01,7.04$, 7.06 (1959) [hereinafter cited as DAvIs].

355. The absence of compulsory process to require the attendance of witnesses is soinetimes given as a reason for withholding cross-examination. See Buss, Procedural Due Process for School Discipline: Probing the Constitutional Outline, 119 U. PA. L. Rev. 545, 598-603 (1971). But absence of compulsory process only dilutes the effectiveness of cross-examination rights where the witness will not voluntarily appear. Id. at 597. Moreover, coinpulsory process can be included in the procedural scheme adopted either by giving the power to the panel directly or by enabling the panel to petition the court for an order to testify. Both the P.A.R.C. and Mills decisions include provisions for compulsory process, although the Mills decree is limited (perhaps inadvertently) to "any official, employce or agent of the public school system or any public employee who may have evidence upon which the proposed action may be based ...." 348 F. Supp. at 880 (If 13(e)(12)). P.A.R.C. more broadly included "any witness testifying for the school board or intermediate unit . . . ." 343 F. Supp. at 305 . Since the courts have general power to compel testimony, either decree could easily be enlarged.

356. See Dixon v. Alabama State Bd. of Educ., 294 F.2d 150 (5th Cir. 1961).

In the instant case, the student slould be given the names of the witnesses against him and an oral or written report on the facts to which each witness testifies. He should also be given the opportunity to present to the Board, or at least to an administrative official of the college, his own defense against the charges and to produce either oral testimony or written affidavits of witnesses im his behalf. 
its case "beyond a reasonable doubt." ceedings where an adverse finding would subject a person to serious deprivation of liberty other than incarceration, the standard of proof is lower, but the burden of proof remains on the government to establish the facts that would justify deprivation. ${ }^{358}$ This burden-of-proof allocation is consistent with the basic concept of fundamental fairness that dictates that a person threatened by governmental action and serious loss of freedom be equipped with procedural safeguards. ${ }^{360}$

Assigning the burden of proof to the school administration is justified by several considerations. ${ }^{380}$ Most of the significant factswhat the child has done and failed to do in school, the child's test scores, the circumstance of testing, the choice of tests, the effect of the child's behavior or learning problems on others-are within the possession or control of the school administration. In addition, the burden of proof is ordinarily assigned to the person seeking to change the status quo (i.e., the child needs special education) rather than to maintain it (i.e., no change im his education program is necessary). Further, the argument for allocating the burden of proof to the school administration-making it justify changing the child's life-is considerably reinforced by the general acknowledgement that a special education assigninent tends to be a "one-way" street. As long as relative irreversibility is a fact, there should be real threshold obstructions in the way of initial special-education assignments.

The burden-of-proof allocation suggested here coincides with obtaining desirable outcomes in certain kinds of cases, based on what is presently known about special education. Criteria for deciding that special education is needed for mildly handicapped children are in dispute: consequently, it would be relatively difficult for the administration to succeed in meeting a burden of proof in such cases. Where there is considerable doubt about whether an assignment of certain

Id. at 159. Whether or not the right to present or cross-examine witnesses is recognized, the parents might have the right to "discover" and examine all documentary evidence as required by both the P.A.R.C. and Mills cases. See 348 F. Supp. at 880 (II $13(\mathrm{e})(10)) ; 343$ F. Supp. at 305 (ा 2(r)).

357. In re Winship, 397 U.S. 358 (1970).

358. See, e.g., Administrative Procedure Act, $\$ 7$ (c), 5 U.S.C. $\$ 556(d)$ (1966). But see Roth v. Board of Regents, 310 F. Supp. 972, 980 (W.D. Wisc. 1970), rev'd on other grounds, 408 U.S. 564 (1972).

359. This view probably best explains the presumption in favor of regular classroom placement established in both P.A.R.C. and Mills. See 348 F. Supp. at 881 (IT 13(e)(8)); 343 F. Supp. at 305 (I 3(o)). See also CaL. Educ. Code $\$ 6902.06$ (West Supp. 1973), which specifies that no assignments should be made to special programs if children "can be served in regular classes"; MAss. GEN. LAws ch. 71B, § 3, II 1 (Supp. 1973) (effective Sept. 1974).

360. See generally 9 Wigmore, EVIDENCE \$§ 2483-89, 2537 (3d ed. 1940); 1 L. FUller \& R. BRAUCHER, BASIC CONTRACT LAW 636 (2d ed. 1964). 
children to special education programs will be truly beneficial, this means of "slowing down" the schools is desirable. On the other hand, the justification for assigning seriously handicapped children to special education programs is undisputed. In these cases the burden of proof will be easy to satisfy and the proper result obtained.

\section{Criteria for Decision}

The ground upon which a decision must be based marks the imtersection of procedure and substance. Unless a decision is predicated on identifiable and reasonable criteria, the requirement of procedural protection becomes an elevation of meaningless formality. On the other hand, the existence of wise and reasonable criteria will be of no avail unless individuals affected by those criteria have procedural avenues through which they can insist that the applicable criteria be fairly applied in their own cases.

Where comprehensible criteria for official action exist, due process procedures help to ensure consistency in the treatment of like cases by minimizing bias and caprice, and they ensure the existence of a legitimate basis for governmental actions that will seriously affect private interests. Due process proceedings force officials to articulate and prove the basis for proposed action and enable the individual threatened to show the absence of an acceptable basis in law or fact, or to demonstrate that the actual basis for action is other than the one claimed. By driving the process out into the open, unwise and unacceptable decisions can be identified and corrected. Consistent exposure itself tends to ehminate palpably untenable grounds.

In the classification context, however, it is very difficult to articulate comprehensive and satisfactory criteria for all special education decisions; and a requirement that classification decisions be based only upon articulated criteria would tend to eliminate valuable flexibility. The complexity of classification problems, the number of possible variables, and the importance of intuitive professional judgment all point to the need for flexibility. The difficult question is how to conbine this flexibility with criteria sufficient to prevent capricious, imconsistent, and unexplained decisions.

Flexibility will be determined in part by the nature of the criteria used. At least four different types of criteria can be identified: (1) facts concerning the classified student; (2) facts concerning the school system's capacity to meet the student's educational needs; (3) facts concerning possible disadvantages resulting from special classification; and (4) peripleral facts bearing only indirectly on the classification decision. 
All four types of criteria should be used in determining the need for special classification, and a second set of criteria might be necessary then to determine the proper program in which to place a child. Many of these criteria clearly require an exercise of judgment; since in each case application of the relevant criteria might indicate different results, they do leave rooin for flexibility and careful balancing of costs and benefits both to the particular child and to the school system. Given the need for flexibility, the necessity of relying on informed expert judgment, and our limited knowledge about many aspects of special education, we suggest that placement decisions call for the establishment of criteria through a process of common-law evolution. While great scope should be left to professional discretion, limits can be imposed by permitting parties to submit specific education plans supported by reasons and requiring all decisions-even those resting on intuitive judgments- to be explained.

\section{The Decision-Making Body}

So far we have assumed the existence of a neutral review panel that would perform a court-like function. The school administration and someone acting for the child would each make some kind of presentation, and the panel would decide the case. Decision by an impartial, objective third party is certainly a fundamental aspect of traditional due process. Yet decision by a panel on a hearing record is clearly not the only way to make classification decisions-and is not inevitably the best way. We do not assert that each of the approaches to decision-making outlined below would comport with the demands of traditional due process of law. We do reemphasize, though, that the requirements of due process, constitutional and otherwise, depend upon what is fair and feasible in each particular context Thus, if some form of procedure does not deny much that is of real benefit to the child coinpared to alternative procedures, and yet is much less costly, there is reason to conclude that the procedure constitutes due process. The following are alternatives, in whole or in part, to the review panel decision-making model.

\section{a. Administrative Finality}

One alternative would be for the administrative decision of the school to be final. This is the system generally prevailing now. Its obvious advantages are simphicity and efficiency, and a tendency to relate responsibility to decision-making. In a highly homogeneous community where there was a high level of trust and confidence in the judgment of both school administrators and psychologists, this would be an ideal system. But in large cities there is nothing approaching 
such a community, and special education programs are severely criticized. To note one painful illustration, there will certainly be no confidence or trust in the decisions of mainly white educators as long as they continue to classify dispropontionate numbers of black children in special categories.

\section{b. Professional Control}

The professional decision-maker has special knowledge, training, insight, and experience that, arguably, enable him to make the best possible classification decisions Ideally, the expert or professional should know which records to examine, which tests to give, what consultations to inake, what persons to interview, and what questions to ask in order to establish a basis for a correct decision. Furthermore, the professional, disinterested viewpoint should remove any question about impartiality. Were classification decisions made by such ideal professionals, either no review, or review only by other comparable professionals, would be required.

The expert judgment of the educational psychologist should always play an important part in formulating classification decisions. But in reality the psychologist's professional judgment may too often be distorted or deflected by the needs or the value system of the regular school hierarchy. Therefore a second alternative procedure based on professional judgment should somehow insulate the deciding professionals from the influence of these undermining forces. Such insulation might be accomplished in a number of ways, but the purpose would be always to ensure decision-making by educational psychologists immune froin control and influence by the school administration and not reversible by the school administration. Taking the psychologist completely out of the regular school system for all purposes-hirmg, firing, evaluation, promotion, and compensation-might accomphish this end. But there would be at least two very significant disadvantages: first, it would require a truly Herculean reorganization of the present system; ${ }^{361}$ and second, reinoving educational psychologists froin the regular system would probably reduce their ability to harmonize efforts with the classrooin teacher.

Rather than leaving imitial classification to the psychologists, one could guarantee "professional finality" by subjecting initial decisions by school administrators to professional review. The feasibility of this approach would depend on the availability in adequate numbers of

361. The necessary separation might be approximated by having the psychologist work for a different level of government (such as the county rather than the school district) or a different department (such as Welfare rather than Education), but even this would involve a substantial change in existing arrangements, 
qualified professionals sufficiently disassociated from the school administration and the schools' own educational psychologists to be truly independent and impartial. It also raises questions about the process by which the reviewing professionals would apprise themselves of the information necessary to exercise professional judgment. At one end of the spectrum, a reviewing panel composed of educational psychologists could operate in a traditional adjudicatory fashion and base its decision on a formal hearing record. At the other extreme, the reviewing board (or person) could simply take over the case and make a de novo determination.

\section{c. School/Parent Negotiation ${ }^{362}$}

A completely different means of taking the classification decision out of the unilateral control of the school administration would be to require that the administration negotiate with parents. This approach downgrades the professional quality of the decision and upgrades the significance of parental consent. Apart from the dilution of professional input, this alternative raises certain problems. First, there is the problein of inducing parents to utilize their right to bargain. Second, there is the problem of defining the bargaining obligation-how much joint effort is required, what compromises are acceptable, and so on. Third, what lrappens when the negotiating process reaches an impasse? Every system of bargaining must contain an end play-a strike, unilateral action by one of the parties, arbitration, or judicial intervention. Were special education decisions negotiated, a bargaining failure could be followed by any of the alternative procedures available-due process hearing, administrative finality, professional review, judicial intervention, or some form of third-party involvement. A breakdown of bargaining could also mean mandatory preservation of the status quo, giving the parents a veto over any classification decision.

\section{d. Parental Consent}

It is a short step from a procedure requiring bargaining with the parents to a procedure requiring parental consent for particular classification steps. Parental denial of the necessary consent would be final, ind the child would stay in the regular classrooin as before. ${ }^{363}$ This

362. For a thoughtful and exhaustive exploration of considerations relevant to coordination of behavior see Heymann, The Problem of Coordination: Bargaining and llules, 86 HARv. L. REv. 797 (1973).

363. But see text accompanying notes 397-98 infra, for a discussion of "emergency" provisions under which a child would be removed, without parental consent, not to meet the removed child's educational needs but to eliminate conditions detrimental to the well-being of that child, other children, or the educational process. 
veto power may be acceptable if special education is regarded with. great skepticism or if it is considered proper for a parent to have an unchecked power to make even damaging decisions concerning his child-a power that parents clearly have in some contexts. ${ }^{364}$ In many cases, however, parents will not be satisfied with the status quo resulting from exercising a veto over the school's proposed placement, and in such cases the theoretical veto power will be, practically speaking, reduced to leverage--like bargaining power-to extract alternative proposals from the school.

Both the California statutory scheme (as applied to educable mentally retarded and educationally handicapped classifications) and the recently adopted Massachusetts statute give great significance to parental consent. Under the California procedure, a parent must consent, separately, to psychological evaluation for the purpose of making a classification decision and to the child's placement in a particular special education program. ${ }^{365}$ The fact that these consent requirements are abused and disregarded points up the need for either enforcement provisions or incentives to induce compliance. Enforcement is considered, subsequently, under the section on judicial review. Incentives might be provided in a variety of ways. One approach would be to make the absence of valid parental consent grounds for invalidating a classification decision. This device would work somewhat like the exclusionary rule for evidence obtained through unconstitutional confessions and searches. But its effectiveness as a deterrent may be doubted, ${ }^{366}$ as even bad classifications would probably not be challenged consistently; and at any rate it is a patently undesirable remedy whenever the decision invalidated is in fact the best one for the child. Instead, the lack of consent might just require reconsideration rather than permanent abrogation of the previous decision. Another alternative would be to discharge or otherwise sanction any employee responsible for the failure to obtain necessary consents. Discharge might be impossible if there were no labor pool available for replacement. The preferable solution would be to induce compliance with consent requirements by convincing the educators involved that parental consent really does inatter.

The Massachusetts statute creates a procedure under which parents inay reject each of three successive placement recom-

364. See, e.g., Wisconsin v. Yoder, 406 U.S. 205 (1972) (Amish children excused from high school compulsory attendance laws by reason of family religion).

365. CaL. Educ. Code, \& 6902.085 (West Supp. 1973).

366. The exclusionary rule's deterrent effect on police behavior has been questioned. See Oaks, Studying the Exclusionary Rule in Search and Seizure, 37 U. CHI. L. Rev. 665, 674-709 (1970); J. Skolnick, Justiç WITHOUT TrIAL (1968). 
mendations. ${ }^{367}$ Following the last rejection, the parental veto may lead to an action in court. ${ }^{368}$ The criteria to guide the court in deciding the student's fate are, unfortunately, not clear, as the statute just authorizes the court to have the child placed "in an appropriate education program." It seems likely, though, that a court would base its decision on a combination of three factors: the parents' indicated preference (inasmuch as parental consent is emphasized by the statute); the nature of and reasons for the successive placement proposals; and the reasons, if any, given by the parents for rejecting the proposals. Unless the Massachusetts statute suffers the same subversion as the parental consent provisions in California, this triple-consent scheme will give Massachusetts parents a significant power to bend placements proposed by education officials to parental liking. Rather than fight parents down the line to judicial determination, officials are likely to histen to parents, attempt to persuade them, and settle for comprounise placements. This complex system seems justifiable only if it is assumed that parents have either a real contribution to make to the placement process or a moral right to control their children's education, and that the expertise of school administrators and their advisors should be substantially discounted.

\section{e. Judicial Determination}

Resort to judicial review is a possible last step of any procedure, as it is in the Massachusetts scheme. But judicial determination could be given a featured role early in the classification process. Early or late, lowever, the question is low completely will a court examine an administrative decision to classify a child, for the scope of judicial review will significantly influence the frequency of resort to the courts. Courts generally lack any expertise in the field of special education, and judicial proceedings are apt to be slower, more cumbersome, and

367. Mass. Gen. Laws ch. 71B, § 3, đা 12-13 (Supp. 1973) (effective Sept. 1974). If, after the second rejection, the parent desires a regular rather than special program, he gets only two rejections rather than three. Id. at $\Uparrow 13$.

368. When the parent opts for a regular education program, the court action is initiated by the local "school committee," i.e., the Board of Education, if, but only if, the desired assignment would be harmful to the child or disruptive for others; otherwise the assignment desired by the parent must be given. When the parent opts for a special program, the initiation of court action appears to be left to the parent, but the statute is not clear. Prior to court action, the statute requires reference to a "state advisory commission on special education" for a "determination" by the commission; then, if "the parent rejects this determination, they may proceed to superior court. ..." If "they" refers to the parents, it appears that a parental failure to initiate judicial proceedings leaves the matter in limbo and leaves the child where he started in the regular program. On the other hand, the statute might be construed-contrary to a biteral reading-to permit a parental rejection only in coujunction with the initiation of coụrt proceedings. Or, "they" might refer ungramatically to the commission. 
less flexible than alternative administrative proceedings. On the other hand, the finality of judicial action may be valuable; and if the case is likely to end up in court anyhow, there is much to be said for getting it there quickly.

\section{f. Third-Party Intervention}

In addition to any of the alternative procedures thus far suggested, some systein of third-party imtervention could be adopted. Perhaps the classic example is the mediator's intervention in bargaining situations. A mediator in classification procedures would not take over the responsibility of decision-1naking, but would intervene into a previously bilateral process (such as school-parent negotiation) and attempt to help the parties reach an agreeinent. ${ }^{369}$ Somewhat similarly, an ombudsman ${ }^{370}$ might be used to help the parties better utilize the procedural system or arrive at a solution that can be validated by the decision-inaking systein. An ombudsman might also perform the much less restrictive role of proposing changes in the system as a whole on the basis of accumulated experience with individual cases. This latter role is important when there is no clear solution to the problems of appropriate procedure or appropriate criteria. It is comparable to the role of the two masters in the P.A.R.C. case: ${ }^{371}$ although they were appointed for the express purpose of aiding the court in enforcing its decree, the masters were expected to recommend solutions to unanticipated problems as they arose. Finally, an independent agency representing the child's interest ${ }^{372}$ could be considered an intervening third party.

\section{The Composition of the Panel}

A central feature of the due process model is the competent, impartial, decision-1naking tribunal-the review panel. The ideal panel would be composed of an educational psychologist, a lawyer, and a lay member not a psychologist, lawyer, or educator. The psychologist would be specially qualified to examine critically the technical basis of the administrative classification proposal and any contrary presentation, and to explam this technical information and his own analysis of

369. See, generally, Fuller, Mediation-Its Forms and Functions, 44 S. CAL. L. Rev. 305 (1971); Stevens, Mediation and the Role of the Neutral, in FrontIERs of Collective Bargaining (J. Dunlap and N. Chamberlain eds. 1967).

370. For a sample of the extensive literature about the ombudsman see $\mathbf{S}$. Anderson, Ombudsman Papers: American Experience and Proposals (1969); S. ANDERson \& J. MOORE, Establishing OMbUdSMaN OFFices: ReCENT EXPERIENCE IN THE UNITED StaTes (1972); W. GELLHORN, OMBUdSMEN AND OTHERS (1967).

371. See 334 F. Supp. at 1267.

372. See text accompanying notes 121-27 supra. 
it to the other panel members. Although there are precedents for medical board members making independent examinations of the physical or mental condition of a party, ${ }^{878}$ all of the panel members, includimg the psychologist, should ordinarily confine themselves to information presented at the panel hearing. This would help ensure that the "scientific" nature of the classification decision would not be exaggerated, that the psychologist would not be regarded as a super-member of the panel, and that the psychologist would not displace the school administration's and parents' own experts. The psychologist would, however, fill a vital role im evaluating the qualifications and methodology of the school's psychologists. This role would be especially important if the parent did not have the assistance of his own expert; and presumably the psychologist would urge the panel to demand retesting or additional expert testimony when appropriate.

The lawyer's role would be to provide expertise in the systematic and efficient development of relevant evidence. This lawyerly skill would be valuable not only im sifting and evaluating evidence, but also in conducting and controlling the hearing. When the parent was not represented by counsel, the panel lawyer would also help compensate for the lack of this assistance.

The third panel member would cast a potentially decisive vote and would perform a jury-like role, providing a lay perspective. It is arguable that the panel's third person should be an educator on the ground that education is the third field of special knowledge that would be particularly useful. ${ }^{374}$ But this choice would seem to load the dice in favor of the school system's evaluation and would thercfore detract from the panel's impartial character.

There is a danger that the educational psychologist, because of his expertise, would dominate the other two panel members. But the lawyer's familiarity with formalized proceedings and with ordering, weighing, and comparing all the evidence-should counterbalance the influence of the psychologist. There is also a danger that the lawyer

373. See, e.g., McCarthy v. Industrial Comm'n, 194 Wis. 198, 215 N.W. 824 (1927).

374. The third member of the appellate hearing body proposed under the P.A.R.C. decree is an educator. See MASTERS' REPORT, Nov. 6, 1972. In Califomia, local admissions committees are composed of an administrator in charge of special education programs in the district or county or other administrator designated by the school district or county superintendent of schools, a school psychologist, a special education teacher, and a school nurse. CAL. EDuc. CODE $\$ 6902.05$ (West Supp. 1973). Hearing panels that deal with parental objections to withdrawals of children from certain programs are composed of either a school psychologist, a special education teacher, and a special education administrator, $i d$. $\$ 6902.09$, I 2, or a school psychologist, the medical director of the nearest regional center for the mentally retarded (or his appointee), and a special education teacher, $i d$. $\{3$. 
(or the third member) would become overly impressed with his own newly gained scientific knowledge; but the presence of the genume expert should chill any such tendency.

It is critically important that the panel be both competent and impartial. Both qualities are necessary if the panel is to have the selfconfidence to evaluate objectively school administration classification decisions. The panel can have the necessary impartiality only if all panel members are immune from any influence from either side. Panel members should not be appointed, compensated, approved, or subject to any control by the school administration. Further, the educational psychologist should not have a professional career so parallel to that of the school psychologist that he will have a natural tendency to "go along with" the school psychologist's position.

It seems doubtful that the hearing officers under either the P.A.R.C. or Mills decree have been sufficiently impartial and competent. In Pennsylvania, all hearing officers are school psychologists or "special educators"375 (a somewhat loose concept that can imclude persons with various psychological, counseling, and curricular preparation), and although they are given some instruction and training, ${ }^{376}$ there is reason to doubt their competence to hold hearings. Furthermore, the hearing officers often hear cases in neighboring towns, and they may have a strong community of interest with the persons responsible for the classification decisions under review. Similar weaknesses inhere in the hearing system spawned by the Mills case. ${ }^{377}$ In addition, while the D.C. hearing officers are forbidden to be schooldistrict employees, they are hired by the city of Washington, D.C., which was a party in the Mills case and is itself the employer of all school district personnel. ${ }^{378}$

It is not easy to decide who should select a hearing panel. One possibility is to have ad hoc panels selected by the means conventionally used to select arbitrators: each of two parties selects one meinber, and the two nommees select a third. The obvious flaw is that this procedure does not adapt easily to the suggested ideal of specialized panel membership. A similar, but slightly preferable system employed under P.A.R.C., entails the compilation of a list of names, with each party given the power to veto unsatisfactory persons on the list. But this alternative works best when only a single hearing officer is required and, again, is imappropriate for a specialized, multi-member panel, unless it is made considerably more complex.

375. See text accompanying note 139 supra.

376. See text accompanying note 136 supra.

377. See text accompanying notes 242-43 supra.

378. See text accompanying note 242 supra. 
Preferably, there should be a single panel selected for a given area for a given period of time. The panel should be named at the state level, with a total membership (in multiples of three) sufficient to meet the state's entire case burden. If necessary, the panel could be subdivided on a regional basis. Panel nembership could require either full-time employment or part-time service, depending on the case load and available state resources. Case load-and thus cost-could be kept down by giving the panel discretion to screen all cases and decide which to hear and by giving the panel clear power to conduct proceedings as expeditiously as possible. Oral presentations could be eliminated when written statements or affidavits would be satisfactory means of presenting the evidence, and cross-examination could be denied when there was no reasonable expectation that it would produce gain commensurate with its cost. It might also be possible for hearing officers to develop a record and then report to the panelwith or without a recommended decision. Such a system would require recruitment, training, and compensation of one or more able hearing officers; but it would reduce the panel's obligations and should reduce the total time and cost devoted to hearings. ${ }^{370}$ If the panel were to function on a state-wide level, it should be appointed at a high level of state government, perhaps by the Governor or the head of the Department of Education. Hearing officers and other staff employees could be hired either by the panel or by the state officer who appointed the panel.

It is important to restate here that it is unrealistic to think of the panel we have hypothesized as an exclusive procedural device. Many of the decision-making procedures separately considered can be combined with it. For example, the use of an onibudsman would not be incoinpatible with the panel-hearing procedure, although each "extra feature" increases cost in ternis of time, energy, attention, and money. Thus, if a state has limited resources and really believes that appointing an ombudsnian would be the inost productive approach, it might just minimize or restrict the role of a hearing panel. Furthermore, the panel device incorporates features of other procedural alternatives. Depending upon the amount of "screening" permitted, it would give greater or less finality to initial administrative decisions. Panel hear-

379. Compare the P.A.R.C. system of appellate administrative review, which is evidently conceived of as the source of additional rights following reasonably fnll procedures before hearing officers. See MASTERs' RePorT, Nov. 6, 1972. Although it is possible to make arguments on behalf of consecutive administrative hearing rights, the authors regard the likely gain from the second full hearing to be outweighed by the cost. A two-tier approach should be adopted only if the two tiers together provide one hearing efficiently or, as suggested earlier, when an initial, very abbreviated hearing will help to justify subsequent selective hearings. 
ings could heighten the role of the parents by providing for parental participation and by increasing the availability of legal and psychological services; and in another way could limit the parents' role via a screening authority. Finally, the panel procedure might ensure a significant role for professional school psychologists both by its own coinposition and by estabhishing rules regarding the use of expert testiinony.

\section{Decision and Opinion}

Written opinions explaining the basis of agency action are probably not constitutionally required, ${ }^{380}$ but a statement of findings and the reasons for a decision is nearly indispensable for effective judicial review. ${ }^{381}$ Reviewing courts, therefore, have frequently required a clear statement of reasons for an agency decision. ${ }^{382}$ Such explanations are also an important step in dispelling any appearance of arbitrariness.

Due process proceedings are ordinarily public ${ }^{383}$-otherwise, a cloud of doubt might hang over their fairness. Moreover, a party threatened with serious injury by the government has a constitutional right to a public hearing, ${ }^{384}$ but not to a private hearing. ${ }^{385}$ But the protection of individual and family interests in privacy nnay soinetimes require that special education classification proceedings be held in private. ${ }^{380}$ Unfortunately, recognition of such interests in privacy has led both Pennsylvania and Washington, D.C., to be unnecessarily guarded about revealing the nature of classification proceedings. ${ }^{387}$ Secret proceedings shield the decision-nnaking process from potentially beneficial public criticism. They tend to make those who control the proceedings paternalistic and possessive-jealous of their prerogatives, self-righteous about their concern for children, and paranoid about second-guessing by the uninitiated. It is essential to subject as much of

380. 2 DAvis, supra note 354 , at $\S \S 16.04 \& 16.13$.

381. Id. at $\S \S 16.01 \& 16.12$.

382. See, e.g., S.E.C. v. Chenery Corp., 318 U.S. 80 (1943); Northeast Airlines v. C.A.B., 331 F.2d 579 (1st Cir. 1964).

383. 1 Davis, supra note 354 , at $\$ 8.09$.

384. See, e.g., In re Oliver, 333 U.S. 499 (1948).

385. See, e.g., F.C.C. v. Schreiber, 381 U.S. 279 (1965).

386. In Pennsylvania, a parent can choose a private or public hearing, and approximately two-thirds have chosen the former. Presumably any statutory or constitutional right of privacy can be waived by the parent. But see text accompanying note 333 supra.

387. See text accompanying notes $142 \& 242$ supra. In the adıninistration of P.A.R.C., all transcripts and decisions concerning private hearings have been held in the strictest secrecy. See note 386 supra. It appears that anyone may attend a public hearing, and in such cases the decisions, but not the transcripts, are regarded as public documents. 
the classification process to public scrutiny as is consistent with the protection of privacy.

Protection of privacy does not preclude publication of opinions. ${ }^{388}$ If anonymity is important, opinions can easily be written without revealing the child's identity. Opinions need not be elaborate, but they should clearly and concisely state the basis of the decision, making specific references to controlling criteria derived from statutes, regulations, or prior opinions. They should separate the reasons for classifying a child as in need of special education from the reasons for placing him in a particular educational program. If existing programs are inadequate, opinions should state changes that should be made. They should identify clearly facts or values or changes of policy that distinguish one case froin apparently similar cases previously decided. Only if a case contains nothing new should the opinion be reduced to a reference to prior controlling cases. Groups of cases-even large ones-can be explained in one opinion when it would be both efficient and fair.

Opinions must be written and, to be really beneficial, must be published and disseminated to affected persons in some reasonably convenient manner. Explicit opinions will make it possible for courts to review carefully panel decisions. Gradually, the opinions will build up a body of precedent that will provide guidance for both school administrators and parents and eventually will reduce the work load of the panels. When a panel determines that an earlier explanation is wrong or inadequate-or correctly explains what turns out to be a wrong conclusion-it can avoid confusion, guide administrators, and promote consistent application of new policy by identifying its error and explaining the reasons for its changed perception.

\section{Judicial Review}

Administrative agency action significantly affecting individual rights is alinost universally subject to judicial review. Such review is "presumed," and may be constitutionally required..$^{\mathbf{3 8 0}}$ As with all pro-

388. Mills requires a decision in writing within 30 days after the hearing, $348 \mathrm{~F}$. Supp. at 881 ( $(\pi 13(\mathrm{e})(14))$, but does not specify whether it should be public or confidential. P.A.R.C. specifies a "stenographic or other transcribed record," but is silent on the need for a decision. 343 F. Supp. at 305 (I P). "Public" decisions issued after public hearings under P.A.R.C. are routinely filed at the Right of Education officenot distributed. In California, a dissenting member of an admission committee "shall attach to the final recommendation a statement of reasons for such objection," CaL. EDuc. CODE, $\$ 6902.05$ (West Supp. 1973), but again there is no indication whether this statement-or the recommendation-is to be a public document.

389. See generally Abbott Laboratories v. Gardner, 387 U.S. 136 (1967); 4 DAvis, supra note 354 , at $\$ \S 28.06 .07,29.08-.09$; L. JAFFE, Judicial CoNTRoL of Administrative Action 336-53, 381-89 (1965); Buss, Procedural Due Process for 
cedural safeguards, the promise and reality of judicial scrutiny is thought to be an important hedge against arbitrary administrative action.

Judicial review of classification decisions would not only protect parents and children from bad administrative or review-panel decisions; it would provide the sword of judicial enforcement to be used against reluctant parents or school officials. Judicial review therefore should be available on the imitiative of either the panel or the parents. A reviewing court should be able to affirm or reverse a decision of the panel in whole or in part. Grounds for reversal would be that the panel's decision is not supported by substantial evidence on the record as a whole $; 30$ is contrary to the constitution or laws of the state or of the United States; or is inconsistent with the state's policy on special education. These standards of review should give the panel's decision some presumptive correctness but also enable the court to look critically at the entire record, including the panel's opinion.

The panel's decision, if challenged by the parent, should be stayed pending review unless exceptional circumstances require immediate implementation. This reverses the usual rule concerning stays pending appeal, but is justified because it would be extremely undesirable to transfer and re-transfer children to and from special education prograins unnecessarily. But if the child's special need is great and the time for review is long, the argument for a stay pending review weakens. "Exceptional circumstances" inight justify immediate implennentation and also would call for expedited judicial review, perhaps of limited scope.

\section{Other Procedural Issues}

So far we have assumed a school administration initiating an action to transfer a student from the regular classroon to a special education program in order to improve that students educational opportunity, and a child or parents objecting to the proposed assignment as detrimental. We have tacitly assumed that the procedures discussed above have nothing to offer the student whose parents voluntarily acquiesce in the school's classification. Voluntary acceptance of the school's classification would, in fact, be the usual situation unless the entire special-education prograin were faring badly.

When the school administration's classification decision is accepted, the need for deliberative proceedings simply does not arise. There are, however, several problems not covered by the previous dis-

School Discipline: Probing the Constitutional Outline, 119 U. PA. L. REV. 545, 631-37 (1971).

390. See 343 F. Supp. at 305 (I (o)); 348 F. Supp. at 881 (I 13(e)(7)). 
cussion that deserve some attention. First, the student or parents may want a transfer from a regular to a special program, but the school refuses. Second, a demand may be made that the school seek through "outreach" efforts to bring within the public educational framework children previously excluded-regular and special alike. Third, students specially classified require re-evaluation. Fourth, a student because of disruptive behavior may be excluded from the regular program pending a decision on special classification and placement. Fifth, and closely related to the previous problem, children who need special education may be treated as discipline cases. Sixth, an attempt may be made to obtain a decision on a group of classification cases in one proceeding, or to treat one case as a class action. Fimally, rule-making may be used to dispose of various questions that would otherwise be resolved on a case-by-case basis.

\section{Parent Requests for Special Education}

Parent requests for special education entail many considerations quite different from those discussed above. The parent may simply want to meet the child's educational needs, but the potential for parentchild conflicts of interest looms large. Just as the school may be tempted to get rid of unruly children, so, too, may a parent wish to get rid of a problem child. Parent requests should be carefully scrutinized to protect the child's distinct interests.

When a child's special classification is requested rather than imposed by the school, the interests relevant to due process procedures are quite different. The threat of adverse government action is absent; to the contrary, the government might be charged with withholding a benefit if the parent's request for special education is denied. ${ }^{301}$ The distinction generally drawn between termination and demal of a benefit, ${ }^{302}$ while not requiring the denial of a hearing and related procedural safeguards, does suggest that the claim for procedural protection is less compelling when made by a new applicant, such as a parent requesting special education, than by someone resisting a governmentally imposed deprivation.

When the parent requests special classification, the allocation of the burden of proof presents a difficult question. A decision must be made whether the presumption in favor of the regular program should

391. Cf. Goldberg v. Kelly, 397 U.S. 254 (1970).

392. See Roth v. Board of Regents, 408 U.S. 564 (1972). But see id. at 588.89 (Marshall, J., dissenting); Holmes v. New York City Housing Authority, 398 F.2d 262 (2d Cir. 1968). See generally O'Neil, Of Justice Delayed and Justice Denied: The Welfare Prior Hearing Cases, 1970 Sup. Cr. Rev. 161, 176, 202-03, 212-13; Note, Procedural Due Process in Government-Subsidized Housing, 86 HARv. L. REv. 880, 910-12 (1973). 
be displaced by a presumption in favor of the parent's preference, remembering that the school still controls most of the relevant data.

\section{Outreach}

The heart of the complaint in both P.A.R.C. and Mills was that large numbers of children were being excluded from all public schooling because they needed education not available in the regular classroom; and the heart of both decisions was that schools and public officials have an affirmative obligation to provide public education for all such children. This "outreach obligation" has dominated efforts at compliance with the decisions in Pennsylvania and Washington, D.C. But such outreach efforts, while raising many serious problems, should be recognized as transitory phenomena. When the right of all children to be educated through appropriate public school placement is established, improper exclusion will be a rarity and will require no special effort by the normal classification systen. The cost of initial outreach efforts, therefore, should be treated as a temporary cost and not figured into the total costs of maintaining an established procedural systein.

\section{Reevaluation}

In contrast to the outreach problem, the need for student re-evaluation represents a continuing and potentially overwhelming burden on the classification process. It is one thing to contemplate reasonably elaborate procedural safeguards for initial special classification decisions. But if the same procedures are required for annual reevaluation of each classified child, the cost may be inordinate. Yet the present one-way-street aspect of special classification has been a subject of frequent and vigorous criticism, and the need for regular reevaluation is recognized in the P.A.R.C. ${ }^{393}$ and Mills ${ }^{394}$ opinions, the California statute, ${ }^{395}$ and the pending Massachusetts statute. ${ }^{396}$ This is a dilemina, as one conclusion seens irresistible: comprehensive procedural protections cannot be made available for all original classifications as well as for frequent re-evaluations. Compromises must be made.

Original classification decisions should be made with as much procedural thoroughness as is necessary to maximize chances of a right result. Reevaluation procedures should probably be less extensive and might involve some combination of the following steps: (1) School

393. 334 F. Supp. at 1261.

394. 348 F. Supp. at 878.

395. CaL. Educ. Code, $\$ 6902.4$ (West Supp. 1973).

396. MASs. GEN. LAws ch. 71B, § 3, \I 16 (Supp. 1973) (effective Sept. 1974). 
administration and professional employees would make regular written re-evaluations (at least once a year) which would be filed with the panel and sent to parents. (2) Parents dissatisfied with the current placement or the written re-evaluation of their children would request reconsideration by the panel. (3) The panel itself, a panel member, a staff employee, or a hearing officer would study the reports and the parental requests. (4) The panel, on its own initiative or in response to parental requests, would exercise discretion to hear selected cases of general iniportance or particular injustice.

\section{Emergency Reassignments}

Sometimes the disruptive effect of a particular child's presence in the regular classrooin would justify immediate removal before a formal hearing for special classification had been held. The problem is to provide for such emergency removals while ensuring that the procedure will not be used to push out troublesome students the school would like to get rid of.

Immediate removal is justifiable only if there is a reasonable, objective basis for believing that the student will cause either substantial physical harm to himself or to other students or serious extended disruption of the regular classroom. If possible, a full hearing should be held before removal; but when that is not possible, a hearing with the complete panoply of procedural safeguards, mcluding state-provided counsel and psychologists for indigents, should be scheduled as soon as possible after removal. If the full hearing will not be held soon after removal, an abbreviated, emergency hearing should be held before $^{397}$ or immediately after removal, with a full hearing thereafter. ${ }^{398}$ An emergency hearing should determine whether there is sufficient danger of harun or disruption to justify removal pending a full hearing, and if necessary, address the problem of appropriate temporary placement in a special program. The school administration should be obligated to propose proper temporary placement, and the parents should have the option to accept the scliool's proposal or to keep the child out of school entirely until the full hearing.

\section{Discipline}

Special education assignments are not punitive or disciplinary,

397. Cf. Goldberg v. Kelly, 397 U.S. 254 (1970).

398. Cf. Stricklin v. Regents, 297 F. Supp. 416 (W.D. Wisc. 1969). Note that under the procedure required by Judge Doyle for student suspensions, there may be three hearings: (1) the best that can be put together on short notice beforehand; (2) a full hearing at the earliest possible time after suspension; (3) an interim hearing after suspension but before full hearing mainly to determine whether there is the sort of emergency that justifies suspension pending the full hearing. 
and a child should never be disciplined or punished because of special-education needs. Unfortunately, what is conceptually clear is not the same as what really happens. A child who disrupts classes may just be misbehaving, but he may also be exhibiting the need for special educational assistance not being provided. The danger of treating a student in need of special education as a discipline problem led the Mills court to devote an entire section of its decree to discipline cases. ${ }^{399}$

The link between discipline and special-education decisions poses a major difficulty in the attempt to construct satisfactory procedures. This link may even result in excluding froin public schools for disciplinary reasons children who ought rather to be placed in special-education programs. Perhaps the simplest solution would be to provide that any parent of a child excluded for disciplinary reasons could petition the panel to consider special-education classification. This does raise the problem of relying on parental initiative; and it, unfortunately, leaves the parent a Hobson's choice-like the choice between incarceration in a mental hospital or a prison. If the need to make such a choice seems unjust, it must be attributed to defects in our schools or in society at large rather than to some failure of special-education classification procedures.

An alternative to parental initiative would be automatic referral to the panel of all discipline-exclusion cases, either before or after exclusion occurs. This is basically the Mills approach. Its main weakness is the potential burden on the panel; but here agam, a compromise solution might be to adopt some combination of parent and panel imitiative and screening by the panel to select cases deserving a hearing.

\section{Joinder and Class Actions}

One approach for maximizing procedural protections while minimizing cost would be to have the panel hear a number of similar cases together. This could be done either by joining separate individual cases or by permitting a few students to represent a larger group of students similarly situated. Cases could be combined for determination of coininon questions of fact or consideration of common criteria; the remaining individual questions could be resolved in separate proceedings, or at least separate determinations could be made. For example, a collective proceeding could explore the vahidity of a mentally retarded classification for children with a certain I.Q. score on a particular test, with separate consideration of individual placements on the basis of that test.

399. 348 F. Supp. at $880,882-83$ (โT 13 (d) \& (f)). This apparently led many teachers and administrators to conclude that Mills was primarily a discipline case and-in extreme instances-that Mills prohibited any school disciplinary action. See text accompanying note 207 supra. 


\section{Rule-Making}

Review panels should have the power to adopt rules to regulate their procedures. For example, they might adopt rules governing joinder or class actions, or rules dealing with the timing of filing requests for review. Or they might adopt rules that lie somewhere between substance and procedure, such as rules elaborating the criteria by which cases are screened and selected for panel consideration. Such rule-making would solidify the panels' gradually accumulating insights; and input could be beneficially solicited from a broad range of interested parties, including the school administration, teachers, parents and parent groups and other commumity meinbers. The panels should welcome participation by persons who might critically affect the overall success of the special-education program but who would otherwise have no opportunity to contribute or learn of the contributions of others. For example, rule-making proeeedings might provide an important opportumty for both regular and special teachers to become involved in a process that otherwise might seem imposed upon thein from outside. Rule-making proceedings could both elicit responses to existing panel proposals and be a means of gathering information and exploring attitudes on general subjects for future proposals. Professor Kenneth Davis has called the procedure of administrative rule-Inaking "one of the greatest inventions of modern, government."400 Plainly it has potential for greatly improving the quality of any classification procedures adopted and for translating the outcomes of particular hearings into generally applicable principles.

\section{Postcript}

The procedural model sketclied in some detail in Pant III is not the only plausible way to improve decision-making concerning the classification and placeinent of students thought by the public schools to be exceptional. Even if one views the procedural framework as fit for the task, the model balances the divergent interests of children (both "norinal" and "special"), parents, and education professionals in a particular way. The choices which it makes-for example, which sorting decisions are to be subject to thorough review-are, of course, fit subjects for debate in assessing the model.

Nor is proceduralization the only conceivable means of improving decision-making with respect to exceptional children. Present practices could be altered by changing state aid policies, which presently preserve special education categories, and using these funds to induce school districts to attend more fully both to the task of classification

400. K. DaVis, Discretionary Justice 65 (1969). 
and to its consequences. Such fiscal incentives might be coupled with the adoption of a per se rule that children be treated as normal unless the school can clearly deinonstrate both the existence of a significant handicap and a reasonable probability of ameliorating that condition through special placement. The availability of education vouchers to enable students whose educational needs were not being met by public school programs to attend private schools would increase the range of choice available to a given student, and might, in the long run, enable public schools to provide better services to a inore limited chentele. The requirement that school personnel and the parents of a handicapped child jointly draft a contract which specified both obligations and goals to be accoinplished within a limited time period could conceivably render the education systen inore aware of and responsive to the particular needs of special children; the availability of a voucher if the school failed to meet its part of the bargain might serve as a useful enforcement prod. ${ }^{401}$

The inere existence of alternatives to the present system is not justification for change. If the case studies treated in Part II impart a common lesson, it is that the organizational attributes of special education inake even incremental changes difficult to accoinphish. They suggest that any proposed reform, including the procedural model, be tested not in a hypothetical world where coinphance with agreed-upon and clear rules represents the norm, but against the day-to-day conditions of public schools, where difficult choices are constantly made on the basis of imperfect evidence, and in the context of organizational factors which render the status quo coinprehensible, if not wholly laudable. The same point may be made inore positively. Intervention by courts and legislatures which intelligently takes into account the sources of resistance to reform has the potential of reshaping the structure of education decision-making in a manner which may benefit both the students and the system itself.

401. See Gallagher, The Special Education Contract for Mildly Handicapped Children, 38 EXCEPTIONAL CHIIDREN 527 (1972). 


\section{California Law Review}

\begin{tabular}{lll}
\hline \hline VoL. 62 & JANUARY 1974 & No. 1 \\
\hline \hline
\end{tabular}

\section{BOARD OF EDITORS}

Editor in Chief

Christopher H. Schroeder

\section{Executive Editor \\ E. Blizabeth Summers}

Articles \& Book Reviews

Howard atan Latin

Patricla D. Douglass

JULIE E. MCDONALD

GEORGE RUTHERGLEN

ULRICH WAGNER
Notes \& Comments

ROBERT M. JENKINS, III

WIILIAM A. CARDWEIL

Richard DELGado

ROBERT A. GOODIN

JAMES E. HARTLEY

SUSAN SAWYER

ROBERT E. WILLETT

Thomas S. WIIIIAMSON, $\mathfrak{J}_{R}$.

\section{Associate Editors}

Chardes Frederict Adams

PHYYLLIS ANDELIN

JAMES A. AsKEW

WILLIAM T. BARRER

Charles Blank

Paul Clark

GARY JAY COHEN

PhIIIP R. Dlamond

JAMES WALTER EILIS

JEPFREY S. ALLEN

CAROL AMYX

Douglas W. Beck

ANN BRICE

BRUCE A. COHEN

JOHN DANNER

LANT LIU EWART

ALAN M. FENNING

Francis E. FernandeZ

JoSEPH FERRARA

GARY GREENFIELD

JoANNE B. Grossman

JANE W. HALL
JOHN A. GLOGER

DOUGLAS L. HAMMER

MARTIN WAYNe JohNSON

ROBERT L. LAWRENCE

PETER LOMHOFF

RANDALI R. McCatHREN

Alan Mittman

Lise A. Pearlman

LAWRENCE L. HOENIG

Pamela S. JUE

ALAN M. KATZ

MICHAEL J. LAWSON

LAURA W. S. MACELIN

JOHN BARRETT MARKS

BRUCE MAXTMOV

PETER L. MCCORKELL

THOMAS JOHN MILIS

HOWARD M. MOFFETT

Peter MuÑoz

ARTHUR LARRY PASSAR

NoRMAn PINE

Administrative Assistant

Patricia G. SMTth
Managing Editor

RANDALL IRA BARKAN

Managing

MARY M. LOGALBO

Research

ELIOT S. JUbeliRER

Thom Greenfield Seaton

Patrick W. Walsh

\author{
Larry Peitzman \\ JOSEPH P. POWERS \\ JAMES D. RICHMAN \\ HENRY SHIELDS, $J_{R}$. \\ ScotT SonNe \\ NANCY E. SULLIVAN \\ ANNE MCLEOD TREBLLCOCK \\ Catalina Valencia \\ David L. Wagner \\ DOROTHY ROBINSON \\ PAUL M. ROSE \\ Federico Castelan Sayre \\ RAND C. SCHMIDT \\ JAMES SEVERSON \\ RALPH J. SHAPIRA \\ EVELYN R. SinaIKo \\ STEPHEN STUBLAREC \\ RICHARD M. TrAvis \\ EARL J. WAITS \\ H. LeE WATSON \\ WILLIAM H. WEBSTER \\ LOUIS S. WELLER
}

